University of California, Hastings College of the Law UC Hastings Scholarship Repository

Faculty Scholarship

2008

\title{
The Formal Structure of Patent Law and the Limits of Enablement
}

Jeffrey A. Lefstin

UC Hastings College of the Law, lefstinj@uchastings.edu

Follow this and additional works at: http://repository.uchastings.edu/faculty_scholarship

\section{Recommended Citation}

Jeffrey A. Lefstin, The Formal Structure of Patent Law and the Limits of Enablement, 23 Berkeley Technology Law Journal 1141 (2008). Available at: http://repository.uchastings.edu/faculty_scholarship/1109

This Article is brought to you for free and open access by UC Hastings Scholarship Repository. It has been accepted for inclusion in Faculty Scholarship by an authorized administrator of UC Hastings Scholarship Repository. For more information, please contact marcusc@uchastings.edu. 


\title{
The Formal Structure of Patent Law AND THE LIMITS OF ENABLEMENT
}

\author{
By Jeffrey A. Lefstin, Ph.D..$^{\dagger}$
}

\section{TABLE OF CONTENTS}

\section{INTRODUCTION: THE NEW FORMALISM AND THE LAW OF ENABLEMENT}

A. THE NEW Formalism IN PATENT LAW ...........................................1142

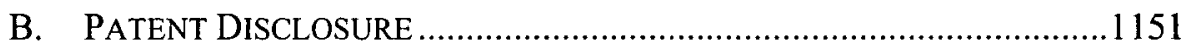

II. PATENT LAW AS A FORMAL SYSTEM …………………….......1159

III. THE LIMITS OF ENABLEMENT ……………..............................1167

A. THE PROBLEM OF INFINITE SCOPE..................................................1168

1. All the World's a Genus: All Claims are Infinite .......................1168

2. What is the "Full Scope" of Infinite Scope? ..............................1174

B. CAN ENABLEMENT LiMIT Claim SCOPE? ......................................1181

1. Claim Scope Without Written Description ...................................1182

2. The Relation Between Enablement and Nonobviousness...........1186

C. RETHINKING ENABLEMENT .......................................................1189

1. Converging Enablement and Nonobviousness ........................1190

2. "Enablement Plus" "..................................................................1193

IV. WRITTEN DESCRIPTION REVISITED .........................................1197

A. WHAT WRITTEN DESCRIPTION IS NOT ...........................................1197

1. Written Description as Possession .............................................1197

2. Written Description as a Priority Doctrine Only......................1200

B. WhAT WRITTEN DESCRIPTION IS: A DOCTRINE OF DEFINITION .......1204

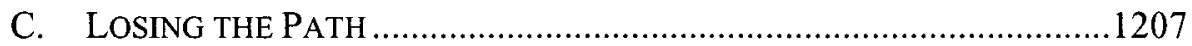

D. ANCHORING THE DEFINITIONAL HIERARCHY ...................................1211

V. THE SIGNIFICANCE OF DEFINITIONAL INFORMATION ........1215

A. CONSEQUENCES OF AN OBLIGATION FOR DEFINITIONAL INFORMATION

(C) 2008 Jeffrey A. Lefstin, Ph.D.

+ Associate Professor of Law, University of California, Hastings College of the Law. The author thanks Margreth Barrett, Robin Feldman, John Golden, Timothy Holbrook, Evan Lee, Michael Meurer, Craig Nard, and participants at the Michigan State University College of Law Intellectual Property and Telecommunications Workshop, and the Eighth Annual Intellectual Property Scholars' Conference for useful comments. 
B. MEANING AND THE Place of DEFINITIONAL INFORMATION IN PATENT DOCTRINE.

\section{INTRODUCTION: THE NEW FORMALISM AND THE LAW OF ENABLEMENT}

\section{A. The New Formalism in Patent Law}

Modern patent law has recapitulated the circumstances of its birth. American patent law was first consolidated in the period between the Civil War and the end of the 19th Century, when the highly formal system of thought, described as classical legal orthodoxy, captivated the American legal mind. ${ }^{1}$ As an intellectual structure, classical legal orthodoxy was primarily characterized by:

A strong commitment to abstract legal categories, and the clear differentiation of one category from another. ${ }^{2}$

A desire to derive bottom-level legal rules analytically from a few basic top-level categories and higher principles, akin to Euclid's derivation of the whole of geometry from five fundamental axioms. ${ }^{3}$ Inherent in this process was the condensation of legal rules, previously scattered among functional categories or forms of action, around a few key principles such as negligence and fault in tort, or offer, acceptance, and consideration in contract. ${ }^{4}$

A preference for objective rules over vague standards. ${ }^{5}$ If not motivated by the ascendant business community's demand for legal predictability, this preference met the community's needs for clear legal rules upon which investment decisions could be predicated. ${ }^{6}$

Classical legal orthodoxy's emphasis on generalization, abstraction, and categorization extended to nearly all fields of American law, ${ }^{7}$ and

1. See Thomas C. Grey, Langdell's Orthodoxy, 45 U. PIrT. L. REV. 1, 2 (1983).

2. See id. at 12 .

3. See id. at 11-12, 16 .

4. See id. at 9-10.

5. See id. at 11 .

6. See id. at 33-35.

7. See Morton J. Horwitz, The Transformation of AmErican LaW $1870^{\circ}$ 1960: THE CRISIS OF LEGAL ORTHODOXY 10-31 (1992). 
patent law was no exception. ${ }^{8}$ Like many other bodies of law, patent law became committed to a formal and abstract system inspired by the logical principles of science. The most fundamental change in patent law during this period concerned the mode by which patentee's rights were defined. Before the mid-19th Century, patent infringement was judged simply by comparing the invention described in the patent's disclosure with the accused device or process. ${ }^{9}$ However, over the latter half of the century, an inventor's rights came to be defined not by what the inventor actually made or disclosed, but by formal "claims" that specified the precise boundaries of the inventor's exclusive right. Precise claiming provided clear notice of the patent's boundaries to the public, competitors, and other inventors. For classical legal thinkers, however, a precise claiming system was more than a means to achieve predictability in patent rights. It was essential in a conceptually ordered legal system. The deep theoretical connection between the claim system and the ideal of conceptual order is clearly evident in Merrill $v$. Yeomans, a pivotal case that cemented the primacy of the patent claim:

The growth of the patent system in the last quarter of a century in this country has reached a stage in its progress where the variety and magnitude of the interests involved require accuracy, precision, and care in the preparation of all the papers on which the patent is founded. It is no longer a scarcely recognized principle, struggling for a foothold, but it is an organized system, with well-settled rules, supporting itself at once by its utility, and by the wealth which it creates and commands. The developed and improved condition of the patent law, and of the principles which govern the exclusive rights conferred by it, leave no excuse for ambiguous language or vague descriptions. The

8. See generally Samuel Oddi, Regeneration in American Patent Law: Statutory Subject Matter, 46 IDEA 491, 520-34 (2006).

9. See Karl B. Lutz, Evolution of the Claims of U.S. Patents, 20 J. PAT. OfF. SoC'Y 134, 147 (1938) (explaining that in the period from 1836 to 1870 "claims rarely, if ever, received consideration on the question of infringement"). This practice may seem puzzling today, but the notion that the patentee has exclusive rights to a set of things bearing the properties recited by the claim is a relatively recent development. In the early 19 th Century, the patentee was required to show what was novel about the invention. A patentee could not describe as his invention, a clock for example, with a novel mainspring, because the other components of the clock would be "old" and the patentee would be accused of claiming the old and the new together. Claims defined the novel feature or principle of the invention, not necessarily an actual embodiment, and therefore ensured that the patent would not be held invalid for lack of novelty. See also text accompanying notes 259-265 infra. 
public should not be deprived of rights supposed to belong to it, without being clearly told what it is that limits these rights. The genius of the inventor, constantly making improvements in existing patents - a process which gives to the patent system its greatest value - should not be restrained by vague and indefinite descriptions of claims in existing patents from the salutary and necessary right of improving on that which has already been invented. It seems to us that nothing can be more just and fair, both to the patentee and to the public, than that the former should understand, and correctly describe, just what he has invented, and for what he claims a patent. ${ }^{10}$

For the Merrill Court, adequate notice to the public and other inventors was not the only consideration in favor of limiting the patentee's rights to the claim. In parallel with these practical concerns was an intellectual linkage between the system of claiming and the ideal of patent law as "an organized system, with well-settled rules." "11 An ordered and logical system of patent law demanded nothing less than an ordered and logical system for defining patent rights. The system of peripheral claiming, in which the claims set forth the boundaries of the patent, served both ends.

If the late 19th Century was the first great period of formalism in American patent law, then the past several decades have been the second. It is critical to understand that by "formalism," I do not mean simply that the substantive doctrines of patent law have gravitated towards bright-line rules in place of looser standards, although scholars have identified such trends in the patent jurisprudence of the Supreme Court and the Court of Appeals for the Federal Circuit. ${ }^{12}$ Instead, I refer primarily to the classical ideal of a conceptually ordered system founded upon a small number of abstract categories and concepts. Thus by formalism I mean that the courts have become committed to a highly formal conception of the patent itself; it is the legal structure of the patent system that has become formal, not just its particular doctrines. ${ }^{13}$

10. Merrill v. Yeomans, 94 U.S. 568, 573-574 (1876).

11. Id. at 573 .

12. See Timothy R. Holbrook, The Supreme Court's Complicity in Federal Circuit Formalism, 20 SANTA Clara COMP. \& HIGH TECH. L.J. 1 (2003); John R. Thomas, Formalism at the Federal Circuit, 52 AM. U. L. REV. 771 (2003) (citing Holbrook). The Federal Circuit since 1982 has been vested with nearly complete and exclusive appellate jurisdiction over questions of patent law.

13. See Grey, supra note 1, at 1-12 (distinguishing between a preference for rules over standards, and a commitment to analytically deriving those rules from top-level 
The cornerstone of that formal system is the claim, which today is the defining characteristic of patent law. Claims delineate exactly the subject matter over which the inventor is entitled to exclude others from manufacture, use, or sale. The claim is the sole measure of the invention; all questions of patent infringement, validity, and inventorship, are resolved by reference to the subject matter defined by the claim. ${ }^{14}$ In modern parlance, the claim, "the invention," and "the patent" are essentially synonymous. ${ }^{15}$

Modern claims are themselves highly formal entities. They recite a set of characteristics, or properties, that define the subject matter encompassed by the patent. The more properties or characteristics the claim recites, the smaller the scope of the subject matter it defines. This structure corresponds to the concepts of intension and extension prevalent in classical logic and derived ultimately from Aristotle: as the number of properties or characteristics defining a class grows larger, the number of objects to which it applies becomes smaller. ${ }^{16}$ Most patents contain ordered, hierarchical pyramids of claims in which more and more properties are recited to define successively smaller slices of subject matter. Typically, patentees begin with a broad claim reciting as few properties as possible to yield the broadest claim permissible in light of the prior art and the patentee's disclosure. To these broad claims they generally attach narrower "dependent" claims. Dependent claims refer back to a broader independent claim, but recite additional properties and therefore define a smaller sub-category of subject matter within the independent claim. ${ }^{17}$

principles). According to Grey, late 19th-Century classical legal orthodoxy was committed to formalism at both levels. See id. at 10-11.

14. An exception to this principle is that one who is co-inventor of a claim receives co-ownership of all the claims in the patent. See Ethicon, Inc. v. U.S. Surgical Corp., 135 F.3d 1456, 1460 (Fed. Cir. 1998).

15. Patents typically carry more than one claim, each of which technically defines an "invention." Though the essential synonymy of invention and claim was wellestablished by the time of the 1952 Patent Act, the equivalence of the invention and claim is never explicitly demanded by the Act itself. The Act's substantive validity and infringement provisions speak of "the invention" rather than "a claim"; section 112 of the Act merely requires the patentee to conclude the specification with one or more claims distinctly pointing out what he regards as his invention. 35 U.S.C. $\S 112(2000)$.

16. See William T. Parry \& EdWard A. Hacker, Aristotelian Logic 65-67 (1991).

17. The practical motivation to construct hierarchies of successively narrower claims is to ensure that some claims remain valid. If broad claims are invalidated because it is later discovered that they read upon the prior art, or are too broad in light of the 
Though claims have been the primary measure of the inventor's rights since the mid-19th Century, the Federal Circuit's jurisprudence seems to have driven towards an ideal in which the patentee has an absolute entitlement to all things within the boundaries defined by the claims, but, with the possible exception of developments unforeseeable at the time of patenting, ${ }^{18}$ no rights over any things outside the literal boundaries of the claim. In the law of infringement, the court has worked towards a regime in which any use of subject matter falling within the claims is an act of infringement, regardless of its extent or purpose. ${ }^{19}$ Conversely, with its hostility to the doctrine of equivalents, ${ }^{20}$ the court has tried to prevent patentees from asserting infringement against subject matter lying outside the literal scope of the claims. ${ }^{21}$ With respect to patent validity, questions

patentee's disclosure, the patentee may be able to fall back on narrower dependent claims that are still valid. Because narrower claims encompass less subject matter, they are less likely to encompass prior art or subject matter that the patentee did not enable or describe.

18. See Johnson \& Johnston Assocs. Inc. v. R.E. Serv. Co., 285 F.3d 1046, 1056 (Fed. Cir. 2002) (Rader, J., concurring) (arguing that doctrine of equivalents should not extend to "subject matter that the patent drafter reasonably could have foreseen during the application process and included in the claims"). Judge Rader's argument that foreseeability ought to be the sole principle underlying the doctrine of equivalents recalls the classical program of systematizing unruly legal regimes around central organizing principles.

19. The court has essentially denied the existence of a common-law experimentaluse exemption or an exception for "de minimis" infringement, see Madey v. Duke Univ., 307 F.3d 1351 (Fed. Cir. 2002), and (before being reversed by the Supreme Court) accorded narrow scope to the statutory exemption for activities directed to approval of generic drugs mandated by the Hatch-Waxman Act, see Merck $\mathrm{KGaA} \mathrm{v}$. Integra Lifesciences I, Ltd., 331 F.3d 860 (Fed. Cir. 2003), rev'd, 545 U.S. 193 (2005). The Federal Circuit's rule that permanent injunctions would issue upon proof of infringement absent exceptional circumstances was another example of the absolutist strain in the law of infringement. The Supreme Court limited that rule in Ebay v. MercExchange, holding that injunctions should issue only upon satisfaction of the traditional tests for equitable relief. See eBay Inc. v. MercExchange, L.L.C., 547 U.S. 388 (2006).

20. Created by the courts, the doctrine of equivalents ("DOE") permits a patentee to reach beyond the literal scope of the claims. Under the doctrine of equivalents, accused subject matter may infringe if its elements or properties are substantially similar to those defined by the patent's claims. See Warner-Jenkinson Co. v. Hilton Davis Chemical Co., 520 U.S. 17, 21 (1997) ("[A] product or process that does not literally infringe upon the express terms of a patent claim may nonetheless be found to infringe if there is 'equivalence' between the elements of the accused product or process and the claimed elements of the patented invention.").

21. In Johnson \& Johnston Associates Inc. v. R.E. Service Co., the court has held that any subject matter disclosed, but not explicitly claimed, in the patent's specification is abandoned to the public and cannot be reached under the doctrine of equivalents, 
of novelty have been reduced to exact rules of inclusion or exclusion within the boundaries of the claim, in derogation of the more nuanced approach of earlier times. ${ }^{22}$

In addition to reducing the substantive doctrines of patent law to formal questions of inclusion or exclusion with respect to claim scope, the Federal Circuit, since its founding, has maintained a rigid conceptual separation between the substantive doctrines themselves. The questions of patent infringement and patent validity are both binary determinations; the patent is infringed or not, and it is valid or invalid. The court has determined patent validity independently of the infringement inquiry and without reference to the allegedly infringing device. In particular, the question of patent scope-whether the patentee is entitled to assert

though the court later held that the alleged equivalent must be disclosed specifically in the written description to trigger the dedication rule. See generally Johnson \& Johnston, 285 F.3d 1046; see also PSC Computer Prods. Inc. v. Foxconn Int'l, Inc., 355 F.3d 1353, 1360 (Fed. Cir. 2004). The court also attempted to impose a strict regime of prosecution history estoppel in which any subject once within the claims during prosecution, but not within the final claims, was surrendered and beyond the reach of the doctrine of equivalents. See Festo Corp. v. Shoketsu Kinzoku Kogyo Kabushiki Co., 234 F.3d 558 (Fed. Cir. 2000). The Supreme Court tempered the Federal Circuit's absolute rule by specifying when the patentee could rebut a presumption of surrender. See Festo Corp. v. Shoketsu Kinzoku Kogyo Kabushiki Co., 535 U.S. 722 (2002). While the Festo and Johnson \& Johnston cases drew public attention to the court's hostility to the DOE, Professor Nard had earlier identified this trend commencing in 1991. See Craig Allen Nard, A Theory of Claim Interpretation, 14 HARV. J. L. \& TECH. 1, 68-69 (2000) (noting skepticism towards DOE in London v. Carson Pirie Scott \& Co., 946 F.2d 1534, 1538 (Fed. Cir. 1991)).

22. In assessing whether an invention has been anticipated by a disclosure in the prior art, the court has held that any prior use or sale of subject matter falling within the scope of the claims invalidates the claim, regardless of whether the use or even existence of the subject matter was known at the time. See Schering Corp. v. Geneva Pharms., 339 F.3d 1373, 1377-80 (Fed. Cir. 2003). Earlier case law, which the Federal Circuit in Schering characterized as dicta, had suggested that prior accidental or unknown existence of subject matter within the scope of the claims might not render the patent invalid. See $i d$. at 1378-79 (dismissing In re Seaborg, 328 F.2d 996 (C.C.P.A. 1964)). Other developments towards a regime of absolute novelty include expanding the range of prior art under section 102(g) of the Patent Act that can destroy patentability despite the absence of publication or public knowledge. See, e.g., Thomson, S.A. v. Quixote Corp., 166 F.3d 1172, 1175 (Fed. Cir. 1999) (explaining that activity not otherwise "prior art" may anticipate claim unless abandoned, suppressed, or concealed). Of course, the benchmark for bright-line rules of public use was laid down during the heyday of classical legal orthodoxy, when the Supreme Court held that corset springs were in "public use" when their inventor gave his "intimate friend" a single pair to wear within her corset. See Egbert v. Lippmann, 104 U.S. 333, 335 (1881). 
exclusive rights over a broad range of subject matter-is resolved independently from the question of whether the patentee is entitled to assert exclusive rights over the particular subject matter practiced by the accused infringer. ${ }^{23}$ Formally, it is no defense that the accused infringer is practicing something which was in the public domain before the patent, ${ }^{24}$ nor is it a defense that the accused technology is beyond what the patentee's disclosure enabled. Once the validity is determined, there is no formal relationship between what the patentee is asserting rights over (the accused subject matter) and either the patentee's disclosure, or the prior art. $^{25}$

23. Historically, patent law could take into account the relationship between these inquiries via the so-called "reverse doctrine of equivalents," which exonerated accused subject matter of infringement even though it fell within the literal boundaries of the patent's claims. This doctrine permitted a court to assess infringement in light not only of the degree to which the claimed invention represented an advance over the prior art, but the marginal advance and functional similarity of the accused subject matter as well. See, e.g., Boyden Power-Brake Co. v. Westinghouse, 170 U.S. 537, 569 (1898) ("Even if the patent for a machine be a pioneer, the alleged infringer must have done something more than reach the same result."). However, the Federal Circuit has suggested that the 1952 Patent Act essentially destroyed the doctrine, and has never affirmed a finding of noninfringement under the reverse doctrine of equivalents. See Tate Access Floors, Inc. v. Interface Arch. Res., Inc., 279 F.3d 1357, 1368 (Fed. Cir. 2002). But the disappearance of the reverse doctrine of equivalents has little to do with the passage of the 1952 Act, which largely codified common-law patent doctrine. The reverse doctrine of equivalents is untenable in modern patent law because it is premised on the existence of "the invention" and "the claims" as separate entities, or at least on the significance of that distinction. See Boyden Power-Brake, 170 U.S. at 568 (explaining that the doctrine exonerates the defendant who "has so far changed the principle of the device that the claims of the patent, literally construed, have ceased to represent his actual invention" and invoking a distinction between violation of the letter of a statute as opposed to the spirit or intent thereof) (emphasis added). Such a distinction is incompatible with the modern synonymy of claim and invention.

24. See Tate Access Floors, 279 F.3d at 1365-66 (refusing to accept "practicing the prior art" as a defense to literal infringement). However, infringement under the doctrine of equivalents is explicitly limited by the scope of the prior art. See Wilson Sporting Goods Co. v. David Geoffrey \& Assocs., 904 F.2d 677, 683 (Fed. Cir. 1990) ("Even if this test is met ... there can be no infringement if the asserted scope of equivalency of what is literally claimed would encompass the prior art.").

25. The questions of validity, claim scope, and infringement are still connected in practice by the question of claim interpretation. The parties in suit tailor their claim interpretations to suit their arguments on infringement and validity; a broader claim is more likely to be infringed but less likely to be valid, and vice versa. Moreover, one of the maxims of claim interpretation is that claims should be construed, if possible, to preserve their validity. Thus, as a matter of interpretation, claim scope is determined with an eye towards the arguments raised in connection with infringement and invalidity. If, 
The program of condensing patent law into a rigorously defined system centered on the claim has not proceeded without interruption. The Supreme Court in particular has resisted the Federal Circuit's tendencies toward an absolutist or minimalist model of patent infringement. ${ }^{26}$ However, there can be little doubt that classical legal theorists would have received favorably the vision of patent law as a set of conceptually differentiated, binary determinations founded on the abstract concept of the claim, ${ }^{27}$ as well as the Federal Circuit's desire to provide certain and

however, the claims are textually clear and unambiguous, there is no room for interpretive discretion, and the validity and infringement determinations proceed as entirely disconnected inquiries. We might regard clarity in claim scope as the sine qua none of the formalist program: if claim scope is not certain, then that uncertainty limits the precision of patent determinations no matter how closely the substantive doctrines adhere to the boundaries of the claims. Two trends in the Federal Circuit's claim construction jurisprudence - the emphasis on dictionaries as a source of meaning, and the suggestion that claim construction should proceed by an ordered algorithm-have attempted to formalize claim interpretation as well. However, the Federal Circuit put an end to these trends in its en banc decision in Phillips, de-emphasizing the role of dictionaries and denying the existence of any rigid structure to the claim construction process. The formalist program might well be futile if the boundaries of claims cannot be determined with precision. However, as an intellectual structure, the claim system is still conceptually ordered if a single principle governs the outcome of claim construction. Thus, the principle of Phillips v. AWH Corp.--that claim terms mean what an ordinary artisan in the field of the invention would think them to mean after having read the patent specification and prosecution history-provides a conceptually ordered unity to claim interpretation regardless of whether the outcome in individual cases is determinate or not. Phillips clearly reflects the aspirations of classical legal thinkers: a single unifying principle from which the bottom-level rules of the regime may be derived. See Phillips v. AWH Corp., 415 F.3d 1303, 1313 (Fed. Cir. 2005) (en banc) (emphasizing role of context in claim interpretation).

26. The Supreme Court has restored some of the ground lost by the doctrine of equivalents, see Festo Corp. v. Shoketsu Kinzoku Kogyo Kabushiki Co., 535 U.S. 722 (2002); broadened the scope of the statutory exemption for generic drug approval under the Hatch-Waxman Act, see Merck KGaA v. Integra Lifesciences I, Ltd., 545 U.S. 193 (2005); and emphasized that the grant of injunctive relief is subject to the traditional principles of equitable discretion, see eBay Inc. v. MercExchange, L.L.C., 547 U.S. 388 (2006). One might also view the Supreme Court's decision in KSR Int'l Co. v. Teleflex Inc.- -which declared that the Federal Circuit's "teaching, suggestion, or motivation" test for combining prior art references was but one of several permissible ways to demonstrate obviousness-as rejecting the notion that obviousness can be condensed around a single unifying principle. See KSR Int'l Co. v. Teleflex Inc., 127 S. Ct. 1727 (2007).

27. Horwitz describes how classical legal thinking was dominated not only by the tendency to draw bright-line classifications of legal phenomena but also by the tendency to structure legal inquiries as binary questions of inclusion or exclusion from those abstract categories. See HoRWITZ, supra note 7, at 17-18. Twentieth-Century legal 
predictable patent law upon which investment decisions may be based. ${ }^{28}$ So too would classical legal theorists endorse the efforts by some Federal Circuit judges to condense complex bodies of patent law around single unifying principles, such as the notion that the subject matter requirement of section 101 may be reduced to the question of whether an invention yields a "useful, concrete, and tangible result." 29 And just as classical legal theorists sought to order law as a system of rules formally derivable from a minimum set of higher-order principles, the vision behind the formalist program seems to be a patent law in which the rules of infringement and validity can essentially be derived from a few simple axioms. We might in fact represent the formalist ideals of patent eligibility, patent validity, and patent infringement by three axioms:

All things useful may be claimed;

thinking, according to Horwitz, was more receptive to balancing tests. Id. at 131. One could, for example, conceive of a patent system in which the question of infringement might depend on the degree to which a patent was novel and nonobvious, rather than being an entirely separate question once the statutory thresholds of novelty and nonobviousness have been met.

28. See, e.g., Festo Corp. v. Shoketsu Kinzoku Kabushiki Co., 234 F.3d 558, 577-78 (Fed. Cir. 2000) (justifying limitations on doctrine of equivalents as stimulating investment in improvements by competitors); Aerojet-Gen. Corp. v. Mach. Tool Works, Oerlikon-Buehrle Ltd., 895 F.2d 736, 744 (Fed. Cir. 1990) (en banc) ("The availability of a clear, stable, uniform basis for evaluating matters of patent validity/invalidity and infringement/noninfringement renders more predictable the outcome of contemplated litigation, facilitates effective business planning, and adds confidence to investment in innovative new products and technology."), overruled by, Holmes Group, Inc. v. Vornado Air Circulation Sys., Inc., 535 U.S. 826 (2002).

29. State St. Bank \& Trust Co. v. Signature Fin. Group, Inc., 149 F.3d 1368, 1375 (Fed. Cir. 1998); Thomas, supra note 12, at 788 ("It is difficult to imagine a more simple rule governing patent-eligible subject matter."). The Federal Circuit en banc overruled the State Street "useful, concrete, and tangible result" standard in In re Bilski, 545 F.3d 943, 959-60 (Fed. Cir. 2008) (overruling State Street). Judge Rader, however, believed that the court's complex exegesis of Supreme Court precedent and its "machine or transformation" test could have been condensed into the single principle that abstract ideas are not patentable. See id. at 1011 (Rader, J., dissenting) ("This court labors for page after page, paragraph after paragraph, explanation after explanation to say what could have been said in a single sentence: 'Because Bilski claims merely an abstract idea, this court affirms the Board's rejection." "). The same desire to condense law around a single principle-so attractive to classical legal theorists-seems to explain Judge Rader's view that the myriad restrictions on the doctrine of equivalents may condensed into the question of whether the alleged equivalent was foreseeable. See Johnson \& Johnston Assocs. Inc. v. R.E. Serv. Co., 285 F.3d 1046, 1056-59 (Fed. Cir. 2002) (Rader, J., concurring); Festo Corp. v. Shoketsu Kinzoku Kogyo Kabushiki Co., 344 F.3d 1359,1374-77 (Fed. Cir. 2003) (en banc) (Rader, J., concurring). 
No claim may have within its boundaries any thing existing in, or obvious from, the prior art; and

All things within the boundaries of the claim infringe, and nothing outside those boundaries infringes.

\section{B. Patent Disclosure}

The three axioms given above are insufficient to derive a conceptually ordered system of patent law, because we have not defined an axiom of permissible claim scope. While the doctrines of novelty and nonobviousness define the limits of the inventor's claims imposed by the prior art, an axiom of claim scope must define the extent of the inventor's entitlement as a function of what the inventor has created or described in his patent application. The question of permissible claim scope lies at the heart of patent law. The extent of the inventor's entitlement determines not only the incentive offered to the patentee for creating his invention and disclosing it to the public, but also the balance of incentives between the patentee and future inventors whose improvements may fall within the scope of the patent's claims.

Patent claims delimit the inventor's entitlement. In turn, how broadly the inventor is entitled to claim depends on the nature and extent of what the inventor discloses about the invention in his specification. The modern expression of these principles is in section 112 of the 1952 Patent Act:

The specification shall contain a written description of the invention, and of the manner and process of making and using it, in such full, clear, concise, and exact terms as to enable any person skilled in the art to which it pertains, or with which it is most nearly connected, to make and use the same, and shall set forth the best mode contemplated by the inventor of carrying out his invention.

The specification shall conclude with one or more claims particularly pointing out and distinctly claiming the subject matter which the applicant regards as his invention. ${ }^{30}$

The second paragraph of section 112 requires that the inventor delimit the scope of his invention with claims. In the jurisprudence of the Federal Circuit and one of its predecessor courts, the Court of Customs and Patent Appeals, this obligation is known as the "definiteness" requirement.

30. 35 U.S.C. $\S 112(2000)$. The third through sixth paragraphs of section 112 control the drafting of dependent claims and claims defining the invention by function rather than by structure or, in the case of processes, by acts. 
Modern definiteness doctrine is concerned not with how broad the claims are, but whether the claim language clearly communicates to the public the boundaries of the patent right. ${ }^{31}$ The requirement of linguistic definiteness is modest: only if claims are "not amenable to construction" or "insolubly ambiguous" will they be invalid as indefinite. ${ }^{32}$

In contrast, the first paragraph of section 112 requires that the inventor disclose his invention in the patent specification. One of the central functions of section $112, \mathbb{1} 1$ is to implement the quid pro quo of the patent system: in exchange for disclosing the invention to the public, the inventor receives for a limited time the exclusive rights provided by the patent grant. As set forth by the Court of Customs and Patent Appeals and the Federal Circuit, the doctrinal elements of section 112 are threefold. One element is the "best mode" requirement, which obligates the inventor to disclose (if he has one) his preferred mode of carrying out the claimed invention. The best mode requirement is not a scope doctrine in the sense that I use the term. Although the scope of the claims determines whether a particular preference held by the inventor is subject to the best mode requirement because it is a preferred mode of carrying out "the claimed invention," $" 33$ a greater or more detailed disclosure of the preferred mode does not entitle the inventor to broader claims. Instead, the other two doctrines rooted in section 112, | 1 , "enablement" and "written description," control the inventor's entitlement to a broader scope of protection.

Under the modern doctrine, enablement requires that one of ordinary skill in the art, relying on the disclosure and the information known to those of skill in the art, must be able to make and use the claimed invention without "undue experimentation." 34 The requirement that the

31. See, e.g., Datamize, LLC v. Plumtree Software, Inc., 417 F.3d 1342, 1347 (Fed. Cir. 2005) ("Because the claims perform the fundamental function of delineating the scope of the invention, the purpose of the definiteness requirement is to ensure that the claims delineate the scope of the invention using language that adequately notifies the public of the patentee's right to exclude.") (citations omitted).

32. Id. (stating that test for definiteness is whether claim terms "can be given any reasonable meaning").

33. See Bayer AG v. Schein Pharms., Inc., 301 F.3d 1306, 1315 (Fed. Cir. 2002) ("[T]he best mode disclosure requirement only refers to the invention defined by the claims.").

34. See, e.g., Hybritech Inc. v. Monoclonal Antibodies, Inc., 802 F.2d 1367, 1384 (Fed. Cir. 1986) ("Enablement is a legal determination of whether a patent enables one skilled in the art to make and use the claimed invention, [and] is not precluded even if 
specification's disclosure be commensurate with the scope of the patent claims was articulated early in the history of patent law, ${ }^{35}$ and the existence and nature of the enablement doctrine are uncontroversialthough its application is by no means certain. ${ }^{36}$

In contrast, the nature of the separate written description requirement in the first paragraph of section 112 of the 1952 Act has been enormously controversial. The distinction between the enablement requirement and the written description requirement is, crudely speaking, the distinction between disclosing how to create the claimed subject matter, and disclosing what the claimed subject matter is. ${ }^{37}$ A patent disclosure may provide sufficient technical information for one of ordinary skill in the art to make and use things within the boundaries defined by the claims, but fail to satisfy the written description requirement because it does not disclose the identity or characteristics of the subject matter within the claim. ${ }^{38}$ The Court of Customs and Patent Appeals first articulated a separate doctrine of written description in In re Ruschig, invoking the doctrine to reject claims filed after the original patent application that were directed to an invention not disclosed in the original patent specification. ${ }^{39}$ This priority-policing function of the written description is generally accepted, though it has been argued that section 132 of the Act, which

some experimentation is necessary, although the amount of experimentation needed must not be unduly extensive. ...") (citations omitted).

35. See O'Reilly v. Morse, 56 U.S. 62, 112-20 (1853) (holding invalid claim to all means of communication by electromagnetism when inventor had disclosed telegraph apparatus only).

36. See infra Part III (describing difficulties with enablement doctrine).

37. To illustrate, one may be able to teach an ordinarily skilled mariner how to sail from Spain to North America, but such instruction may not constitute a description of North America. One could also clearly define the boundaries of the United States but such delineation may not suffice as a description of the United States.

38. For example, suppose a patentee discloses a new method of chemical synthesis and a particular compound $A$ that can be synthesized by the method. The new method might enable one of skill in the art to make other compounds $B$ and $C$, but if the patentee has disclosed only $\mathrm{A}$ he may not have described the more general family of compounds embracing A, B, and C. See In re DiLeone, 436 F.2d 1404, 1405 (C.C.P.A. 1971). Likewise, one who describes a generic class may not have described individual species within that class. I might satisfactorily describe the United States but fail to describe a smaller portion of it, such as California.

39. See In re Ruschig, 379 F.2d 990, 995-96 (C.C.P.A. 1967). Without such a requirement, patent applicants could continue to claim inventions not disclosed in their applications while still relying on their original filing date to circumvent the requirements of novelty and nonobviousness. 
prohibits claim amendments from introducing "new matter" into the disclosure, suffices to fulfill this function. ${ }^{40}$

What has been far less accepted is that the written description doctrine also applies to claims that were filed in the original patent application. This aspect of written description doctrine arose, at least in modern jurisprudence, in Regents of the University of California v. Eli Lilly. ${ }^{41}$ In Lilly, the patentee had identified and disclosed the sequence of a DNA molecule encoding the insulin polypeptide from rats. ${ }^{42}$ Despite not disclosing additional insulin-encoding DNA molecules, the patentee claimed DNA molecules encoding human insulin, as well as the broader genera of DNA molecules encoding mammalian or vertebrate insulins. ${ }^{43}$ The accused infringer defended not on the grounds that the patent's disclosure failed to enable any insulin-encoding DNA molecules other than rats', but on the grounds that the patent did not provide a written description of human insulin DNA or the broader genera of mammalian or vertebrate insulin-encoding DNA molecules. ${ }^{44}$ The Federal Circuit, affirming the district court, held that neither the claim to human insulinencoding DNA, nor the claims to mammalian or vertebrate molecules, were valid under the written description requirement of section $112 .{ }^{45}$

In the time since Lilly, criticism of the written description requirement has been intense. A minority of judges on the Federal Circuit have vigorously denied the existence or utility of a separate written description requirement in section 112, arguing that enablement alone should define the scope of the patentee's claims. ${ }^{46}$ A majority of the Federal Circuit

40. See 35 U.S.C. $\S 132$ (2000 \& Supp. II 2002); Enzo Biochem, Inc. v. Gen-Probe Inc., 323 F.3d 956, 978 (Fed. Cir. 2002) (Rader, J., dissenting from the denial of rehearing en banc) (arguing that priority policing function of written description requirement is redundant with section 132).

41. Regents of Univ. of Cal. v. Eli Lilly \& Co., 119 F.3d 1559 (Fed. Cir. 1997).

42. Id. at $1562-63$.

43. Id. at 1563. The claims were specifically directed to "cDNAs," which are synthetic DNA molecules generated from reverse-transcription of protein-encoding RNA molecules.

44. Id. at 1563-64.

45. Id. at 1568-69.

46. To the extent the minority of judges concede that the need for a written description requirement to prevent patentees from adding unsupported claims to existing applications, they believe that such a function is more properly found in section 132 of the Patent Act, which forbids patentees from adding new matter to the specification by amendment. This Article refers to arguments for and against written description as arguments for the position that written description and enablement limit the scope of originally filed claims, or for the position that enablement alone limits the scope of 
remains opposed to revisiting Lilly, though the issue has yielded no fewer than three spirited disagreements on the court's refusal to take the question en banc. ${ }^{47} \mathrm{~A}$ wealth of scholarly commentary has sympathized with the minority position by arguing that the written description doctrine is a dangerous and unnecessary graft onto the traditional law of claim scope. ${ }^{48}$ The arguments against an independent written description doctrine take both the doctrine and its application to task: the doctrine is obsolete under modern claiming practice; ${ }^{49}$ it is unnecessary because original claims by statute constitute their own description; ${ }^{50}$ there has been no coherent differentiation between the requirements imposed by enablement and the requirements imposed by written description; ${ }^{51}$ it is incompatible with current claim interpretation methodology; ${ }^{52}$ it deviates markedly from earlier Federal Circuit and Court of Customs and Patent Appeals precedent; ${ }^{53}$ it is a biotechnology-specific doctrine; ${ }^{54}$ and it has been

original claims. One's position on best mode is peripheral to this question. The inventor need only disclose the best mode of carrying out the claimed invention, if he has a preferred mode. Best mode is therefore not a doctrine of claim scope in the sense that enablement and written description are.

47. See Lizardtech, Inc. v. Earth Res. Mapping, Inc., 433 F.3d 1373 (Fed. Cir. 2006) (denying rehearing en banc); Univ. of Rochester v. G.D. Searle \& Co., 375 F.3d 1303 (Fed. Cir. 2004) (denying rehearing en banc); Enzo Biochem, Inc. v. Gen-Probe Inc., 323 F.3d 956 (Fed. Cir. 2002) (denying rehearing en banc).

48. For review of the critical literature, see Rochester, 375 F.3d at 1309 (Rader, J., dissenting from denial of rehearing en banc) (citing thirty-one articles criticizing Lilly, seven articles defending it, and sixteen neutrally commenting upon it); Christopher $\mathbf{M}$. Holman, Is Lilly Written Description a Paper Tiger?, 17 ALB. L. J. SCI. \& TECH. 1, 17-25 (2007) (collecting criticisms).

49. See, e.g., Mark D. Janis, On Courts Herding Cats: Contending with the "Written Description" Requirement (And Other Unruly Patent Disclosure Doctrines), 2 WASH. U. J.L. \& POL'Y 55, 63 (2000).

50. See, e.g., Enzo, 323 F.3d at 988 (Linn, J., dissenting from denial of rehearing en banc) ("[T]he claims themselves-having been filed as part of the original applicationprovide their own written description.").

51. See, e.g., Holman, supra note 48 , at 80 (arguing that courts have failed to articulate a standard for compliance with written description distinct from enablement).

52. See LizardTech, 433 F.3d at 1376-77 (Rader, J., dissenting from denial of rehearing en banc) (arguing that doctrine is incompatible with recent claim construction jurisprudence).

53. See, e.g., Janice M. Mueller, The Evolving Application of the Written Description Requirement to Biotechnological Inventions, 13 BERKELEY TECH. L. J. 615, 633-36 (1998).

54. See, e.g., Enzo Biochem, Inc. v. Gen-Probe Inc., 285 F.3d 1013, 1025 (Fed. Cir. 2002) (Dyk, J., dissenting) (arguing that Lilly applies a "unique" doctrine to biotechnology). 
applied inconsistently between cases in different technologies ${ }^{55}$ as well as between cases in the same technologies. ${ }^{56}$

Most, though not all, of the critics advocate abolishing the doctrine in favor of enablement as the unitary standard for patent disclosure. ${ }^{57}$ Many of these criticisms stand on their own merits. However, if we place them within the context of the modern program of systematizing patent law into a conceptually ordered formal system, then it becomes clear that the elimination of the written description requirement is an essential element of that program. Obviously, any formal description of patent law requires at least one axiom of permissible claim scope. Why should the formalist conception of patent law entail that enablement be the only doctrine of claim scope? One answer is simply guilt by association. The judges of the Federal Circuit who have consistently opposed the Lilly doctrine also have authored some of the most notable articulations of the formalist program. Nonetheless, there is a deeper intellectual connection between the attack on written description and the desire for a classically ordered system of patent law. Classical legal theorists sought to condense scattered rules and doctrines around core principles such as "fault" or "will." 58 Likewise, the modern classicists of patent law condense the disclosure doctrine around enablement alone, relegating both written description and best mode to peripheral roles. ${ }^{59}$ Classical legal theorists sought unity in generalized categories such of "contract," rather than separate bodies of law devoted to particular industries or relationships. ${ }^{60}$ So too, modern critics who view the written description as a doctrine peculiar to chemistry and biotechnology cases assail the doctrine on the grounds that patent law ought not to be technology-specific. Classical legal theorists sought

55. See, e.g., Dan L. Burk \& Mark A. Lemley, Is Patent Law Technology-Specific?, 17 BERKELEY TECH. L. J. 1155, 1183-85 (2002) (arguing that application of written description doctrine is inconsistent between industries).

56. See, e.g., Univ. of Rochester v. G.D. Searle \& Co., 375 F.3d 1303, 1308 (Fed. Cir. 2004) (Rader, J., dissenting from denial of rehearing en banc).

57. For example, Dan Burk and Mark Lemley seem to approve of the existence of the doctrine, but not its current application by the Federal Circuit. See infra note 235, at 1682-83.

58. See HoRwITZ, supra note 7 , at 13.

59. Judge Rader has argued that a separate best mode requirement is largely unnecessary. See Bayer AG v. Schein Pharms., Inc., 301 F.3d 1306, 1325 (Fed. Cir. 2002) (Rader, J., concurring) (contending that best mode is "little more than . . . a trap for the unwary" and that it was wise for the Federal to have limited the requirement with "the statutory 'scope of the claimed invention' rule").

60. See William M. Wiecek, The Lost World of Classical Legal Thought 102-03 (1998). 
certainty in the law in part to provide stability for business expectations; ${ }^{61}$ modern theorists criticize the Lilly written description inquiry as one that yields no certain results in scope inquiries. ${ }^{62}$

However, these criticisms are secondary to the main intellectual thrust of the attack on written description. Hostility to the written description requirement derives fundamentally from the belief that written description is incompatible with the modern claim. The claim is the abstract legal creature at the heart of modern patent law, and the cornerstone of the conceptually ordered system pursued by formalist thinkers. For those who seek a conceptually ordered system of patent law, written description plays no role in a rational modern system because it is an obsolete relic of an earlier patent law: a patent law without claims. When the earliest United States patent statutes demanded that the patent applicant "deliver a written description of his invention," ${ }^{63}$ patents did not include claims defining the scope of inventors' rights. Early judicial interpretations of the patent statute therefore required that the specification not only enable practice of the invention so as to satisfy the quid pro quo of the patent system, but also define the invention so as to put the public on notice of infringement, and to permit courts to assess the novelty of the invention. ${ }^{64}$ The description of the invention in the specification therefore served the function of modern claims: to define the extent of the patentee's exclusive rights. Claims evolved gradually over the course of the 19th Century, first as formal statements of the invention's novelty rather than definitions of the scope of the inventor's rights. ${ }^{65}$ Later, the claim evolved to represent the subject matter against which the patentee could claim infringementinitially "central" claims, which defined an embodiment around which judges determined the actual scope of patent rights, then later as modern "peripheral" claims, which themselves define the boundaries of the patent right.

In modern practice the claim is "the invention." The set of properties recited by the claim define both the subject matter over which the patentee

61. See Robert W. Gordon, Legal Thought and Legal Practice in the Age of American Enterprise, 1870-1920, in PROFESSIONS AND PROFESSIONAL IDEOLOGIES IN AMERICA 92 (Gerald L Geison ed., 1983). Modern historians have distanced themselves from the position that architects of classical legal thought intended it to fortify the emerging capitalist class. See id.

62. See, e.g., Timothy R. Holbrook, Possession in Patent Law, 59 SMU L. REV. $123,161-62(2006)$.

63. Patent Act of 1793, ch. 11, § 3, 1 Stat. 318, 321 (repealed 1836).

64. See Evans v. Eaton, 20 U.S. 356, 380-81, 391-92 (1822).

65. See supra note 9. 
may assert infringement and the subject matter which may invalidate the patent if known or obvious from the prior art. For those who doubt a modern role for the written description doctrine, claims have entirely supplanted the notice function once performed by the specification's description of the invention. ${ }^{66}$ On this view, written description as articulated by Lilly is an atavism of the time before claims and should have no role in limiting the permissible scope of modern peripheral claims. ${ }^{67}$ The function of the description in the specification is to fulfill the quid pro quo of the patent system: to disclose the invention to the public, so that the public may practice the invention upon expiration of the inventor's exclusive right. That is the function of the enablement doctrine alone. To complete the process of systematizing patent law into a conceptually ordered system grounded upon the peripheral claim, it is necessary to discard remnants of the pre-claim system such as the written description doctrine. Thus, for those who would deny the doctrine of written description, the conceptual ordering of patent law can be largely achieved by adding only one more formal axiom to the set described above:

The maximum permissible boundaries of the claim are what the patentee has enabled in the specification.

In this axiom, "enabled" means what one in the ordinary skill in the art could make and use without undue experimentation.

The object of this Article is to evaluate the formalist conception of patent law and its implications for patent law's substantive doctrines. Identifying the modern patent program as "formalist" or "classical," does not suggest that it represents an obsolete or futile endeavor. The decay of the classical system of legal thought may have come more from its political assumptions than from its epistemological ones, and it is beyond the scope of this Article to evaluate whether the epistemological criticisms leveled at classical legal thought negate the possibility of a conceptually ordered patent system as well. Nor does this Article address whether a conceptually ordered system serves the ends of patent law; both the 19th

66. See Enzo Biochem, Inc. v. Gen-Probe Inc., 323 F.3d 956, 977 (Fed. Cir. 2002) (Rader, J., dissenting from the denial of rehearing en banc) ("In later enactments, this function was assigned to claims, leaving enablement as the only purpose of the "written description' language.").

67. Again, because the Court of Customs and Patent Appeals grounded the "new matter" rejection of new claims in a continuation application in part in section 112 , those who feel bound to respect the CCPA's precedent concede that the "written description" language of section 112 serves that important role. See supra note 46. 
Century and the modern formalist agendas have become too central to patent law to realistically recommend their abolition. Rather, the focus of this Article is on whether the formalist program can succeed on its own terms in formulating a conceptually ordered patent system and whether the written description doctrine is necessary to such a system. This Article asks whether patent law can be reduced to a set of uniform principles centered on a formal and hierarchical model of claim scope. In particular, this Article assesses whether the enablement requirement can satisfactorily limit claim scope in our modern peripheral claiming system or whether additional constraints-such as the written description requirement-are necessary to limit claim scope based on the inventor's disclosure. This Article's approach is in part formal, as it gauges whether a theoretically coherent doctrine of claim scope is possible within the confines of the peripheral claiming system. However, because the question of permissible claim scope is so foundational to patent law, many of the theoretical difficulties this Article highlights will entail balancing the incentives and costs the patent system allocates between patentees, competitors, later inventors, and the public at large.

Part II will consider how the various doctrines of patent law may be expressed as formal statements of inclusion or exclusion from claim scope. It will show that enablement, in contrast to other doctrines, cannot be expressed as a truth function defined in terms of claim scope. Part III will detail the characteristics of enablement that make it incapable, in its present form, of adequately constraining claim scope, and evaluate proposals for modifying enablement to account for these problems. Part IV will revisit the doctrine of written description and argue for its hitherto unrecognized role as a doctrine of definition. Once the written description doctrine is recognized as a doctrine of definition, it will become clear that written description is necessary, though undoubtedly not sufficient, to define the scope of patentable inventions in a peripheral claiming system. Finally, Part V will consider the implications of treating the written description doctrine as a doctrine of definition.

\section{PATENT LAW AS A FORMAL SYSTEM}

Nearly all the doctrines of patent law can be described as a precise relationship between the legal inquiry and the subject matter within the claim's boundaries. These doctrines may be posed almost as mathematical set-functions whose truth value is described in terms of the claimed subject matter. Take a claim reciting particular properties, and call the set of all possible things or events characterized by those properties as $x$. In general, a patent is infringed by the manufacture, use or sale, of anything 
possessing all the properties recited by the patent claims. We may easily represent the question of patent infringement in terms of the members of $x$ :

Let $y$ be the set of all things the accused infringer has made, used, sold, or offered to sell within the United States. The claim is infringed if and only if $\mathrm{x}$ and $\mathrm{y}$ intersect.

We might diagram this rendition of the infringement inquiry as follows:

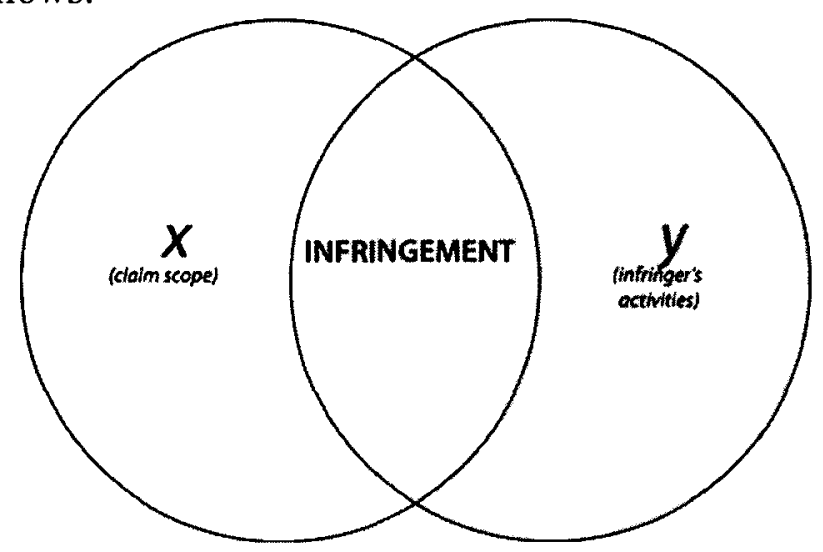

The basic test for patent infringement, therefore, may be reduced to a test of intersection between the accused subject matter and the set of things encompassed by the claim. In practice, this test may be uncertain, for we must construe the language of the claim to define the set of things it encompasses. Claim construction can be a difficult and unpredictable exercise. But the uncertainty associated with claim construction is inherent to nearly all inquiries in patent law, because nearly all patent law doctrines depend on the claim. Moreover, the difficulties of linguistic interpretation are hardly peculiar to patent law. If we concede the baseline uncertainty in interpreting the words of the claim, then at least in theory it is straightforward to define the set $x$, the set of things possessing the properties recited by the claim. Once that set is defined, then the infringement inquiry asks merely whether the accused subject matter falls within that set. ${ }^{68}$

Can the statutory requirements of patent validity be expressed in similar terms? Consider first the novelty provisions of section 102, which generally deny patentability if the invention was known or used by others

68. Of course, there may be factual disputes over whether the accused subject matter actually has the properties recited by the claim, but few areas of law are free from that kind of factual uncertainty. 
before the date of invention. ${ }^{69}$ If the invention is synonymous with the claims, then we can express the requirement of novelty as a simple intersection between the subject matter of the claim and the prior art:

Let $y$ be the set of all things known and used, or patented or described in a printed publication, prior to the date of invention (the prior art). The claim is novel if and only if there is no intersection between $x$ and $y$.

Thus, the claim is anticipated if there is any overlap between the claim scope and the prior art:

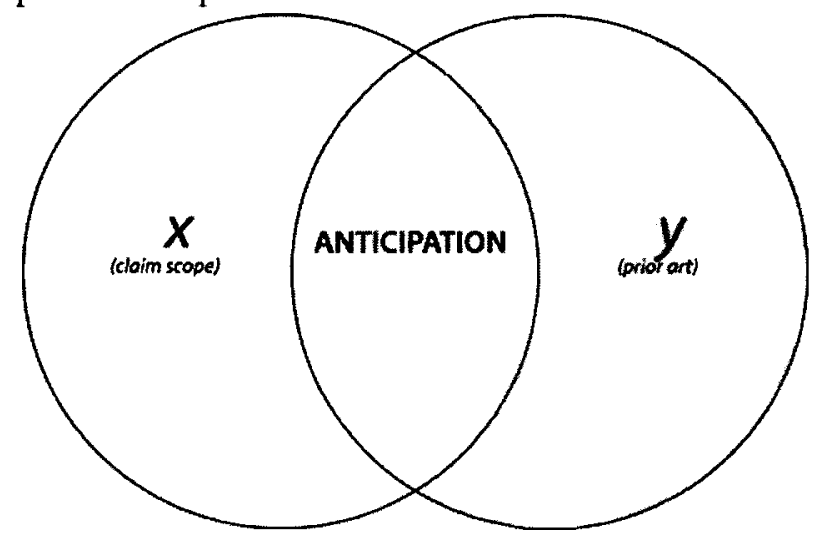

The law governing inventorship, also expressed in section 102, functions similarly: one who contributes to the conception of any element of a claim becomes an inventor not only of the entire claim, but the entire patent, as well. ${ }^{70}$ Likewise, in priority contests between two inventors, reduction to practice of a single embodiment within the scope of the claim generally suffices to establish priority. ${ }^{71}$

69. The statutory bar provisions of section 102 deny patentability to inventions if patent applications are not filed within one year of disclosure or commercialization of the inventor; these provisions function like novelty with respect to claim scope. See 35 U.S.C. $\S 102$ (b) (2000 \& Supp. II 2002).

70. See Ethicon, Inc. v. U.S. Surgical Corp., 135 F.3d 1456 at 1460-64 (Fed. Cir. 1998) (granting inventorship to worker who contributed to conception of claimed features or embodiment falling within means-plus-function claim).

71. Notwithstanding that an inventor establishes priority over a rival by being the first to reduce to practice a single species of the generic invention, the inventor may still be denied a patent if the single species fails to satisfy the disclosure requirements of section 112 with respect to the generic invention. See In re Zletz, 893 F.2d 319, 32-23 (Fed. Cir. 1989); Fried v. Murray, 268 F.2d 223, 225 (C.C.P.A. 1959) (stating that lack of support for full scope of interference count could be a question only of patentability, not priority). The law with respect to conception is not so clear. See In re Jolley, 308 F.3d 
The test of novelty may not be entirely certain, because the scope of the claim - the set of things $x$ having the properties recited by the claimmay be uncertain. In practice, claims may be precise or vague, and the more vague the claim the more uncertain the test of novelty. But practically every inquiry in patent law shares this uncertainty. This Article's aim is not to show that particular doctrines in patent law are certain or uncertain in practice. It is to illustrate where uncertainty lies in the various doctrines of patent law, and, more importantly, to distinguish between the fundamental kinds of uncertainty inherent in the doctrines. Uncertainty in claim scope means that the set $x$ may be difficult to define. However, once we have defined $x$ to whatever degree we think satisfactory or practical, the underlying formal structure of the novelty inquiry is precise. Likewise, the set of prior art $y$ may be uncertain because the standard of whether a thing is "known or used" is not precise. ${ }^{72}$ However, once a satisfactory definition of set $y$ is achieved, the expression of the novelty inquiry in terms of sets $x$ and $y$ is clear.

The requirement of section 103 that the claimed subject matter be nonobvious may also be framed as a relationship between the set of prior art and the set of things encompassed by the claim: ${ }^{73}$

Let $y$ again be the set of all things known and used prior to the date of the invention. The claim is obvious if, for any $y$ or set of

1317, 1322 n.2 (Fed. Cir. 2002) (noting that conception of species may, but not necessarily, constitute conception of a genus).

72. For example, the question of whether subject matter was "known or used" if the property defining the subject matter was not perceived at the time has divided the Federal Circuit. See Elan Pharms., Inc. v. Mayo Found. for Med. Educ. \& Research, 304 F.3d 1221, 1229-351 (Fed. Cir. 2002) (holding that inherent feature of transgenic mouse was not disclosed by reference suggesting method of making mouse); id. at 1241-45 (Dyk, J., dissenting) (arguing that reference inherently disclosed feature that would be present if method performed); see also Elan Pharms., Inc. v. Mayo Found. for Med. Educ. \& Research, 346 F.3d 1051 (Fed. Cir. 2003) (deciding case on enablement rather than inherency grounds); Elan Pharms., Inc. v. Mayo Found. for Med. Educ. \& Research, 314 F.3d 1299 (Fed. Cir. 2002) (order granting rehearing en banc).

73. The Supreme Court made this point in its $K S R$ decision, explicitly defining the nonobviousness inquiry in terms of the set of things encompassed by the claim. See KSR Int'l Co. v. Teleflex Inc., 127 S. Ct. 1727, 1742 (2007) ("What matters is the objective reach of the claim. If the claim extends to what is obvious, it is invalid under $\S 103 . ")$. The Court many years earlier in Graham made definition of the set of prior art the first factual inquiry under section 103. See Graham v. John Deere Co. of Kansas City, 383 U.S. 1,17 (1966) ("Under $\S 103$, the scope and content of the prior art are to be determined...."). 
$y$, the difference between any $y$ and any $x$ would be obvious to one of ordinary skill in the art.

or:

Let $y^{\prime}$ be the set of all things for which the difference between any $y^{\prime}$ and any $y$ or set of $y$ would be obvious to one of ordinary skill in the art. The claim is obvious if and only if $x$ and $y^{\prime}$ intersect.

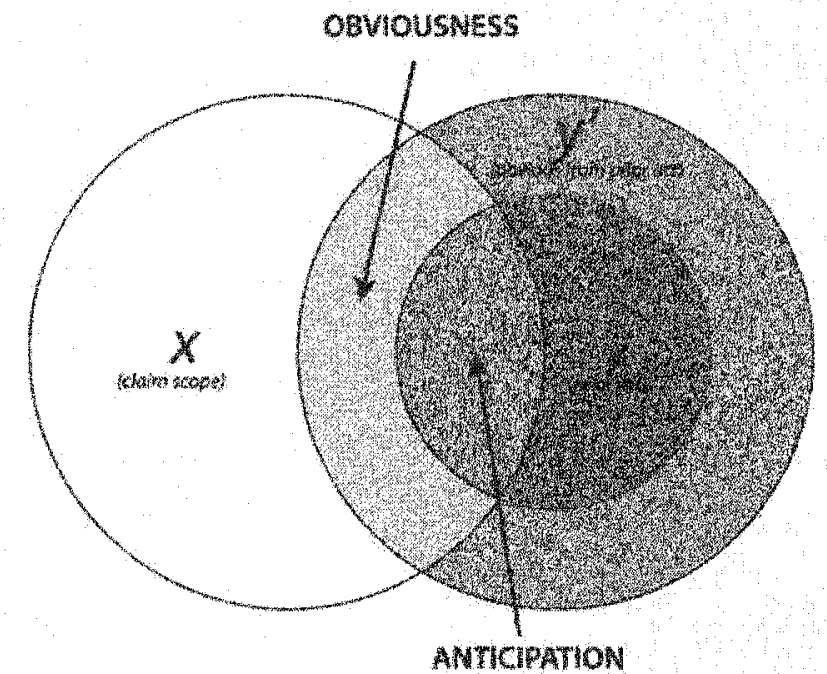

Again, the reader may object that this is not a precise relationship at 11. The transformation between $y$, the prior art, and $y^{\prime}$, the set of all things bvious in light of the prior art, is vague and indeterminate. True, there las never been a certain test of whether the difference between a $y$ and a $y^{\prime}$ vould be obvious to one of ordinary skill in the art, and the test has secome even less certain after the Supreme Court's opinion in KSR Int'l Oo. v. Teleflex $I n c{ }^{74}$ This kind of uncertainty, however, has nothing to do vith the scope of the claim in question. The uncertainty lies in how far the senumbra of obvious objects $y^{\prime}$ extends from the boundaries of the prior Irt objects $y$. Once we develop or posit a determinate method of defining he extent of this penumbra, then the structure of the nonobviousness nquiry is identical to the novelty inquiry: we simply ask whether claim

74. See KSR Int'l Co., 127 S. Ct. at 1727. Before KSR, the Federal Circuit required is an element of obviousness a teaching, suggestion, or motivation for the artisan to ombine or to modify the prior art and arrive at the claimed subject matter. See $i d$. at 734. Under this so-called "TSM test," the set of obvious subject matter $y^{\prime}$ might have seen defined more precisely: something is a member of $y^{\prime}$ if there exists a teaching, uggestion, or motivation connecting the putative member with a member of $y$. See also lolbrook, supra note 62 , at 172 . 
scope $x$ and penumbra $y^{\prime}$ intersect, rather than whether the claim scope $x$ and prior art $y$ intersect. ${ }^{75}$

Similarly, for the doctrine of utility-the requirement of section 101 that the invention be "useful"- -we may define a straightforward relationship between the validity inquiry and the scope of the claim. ${ }^{76}$ As a general matter, if an applicant or patentee establishes the utility of a species encompassed by the claim, then the utility of the claim is established. ${ }^{77}$ Therefore, if we can agree on a satisfactory standard of whether a particular embodiment is useful or not, whether a claim satisfies the utility requirement generally reduces to whether any member of the set $x$ possesses the quality of utility. ${ }^{78}$

75. Professor Durham's treatment has also suggested the restatement of obviousness as intersection. See Alan L. Durham, Patent Symmetry, 87 B. U. L. REV. 969, 995, 997-98 (2007). Durham's discussion of the difficulty in assessing obviousness with respect to "the claim," versus assessing whether some subject matter within the claim is obvious, in some way mirrors the difficulty identified herein with enablement doctrine. See id. at 995-96. This is not an issue for obviousness doctrine, but arises in connection with Durham's suggestion to recast infringement by equivalents in terms of obviousness.

76. As far as the requirement that the invention be within the class of statutory subject matter defined by section 101, the Court of Customs and Patent Appeals assumed, without deciding, that a claim reading on both statutory and nonstatutory subject matter would be invalid under section 101 . See In re Mahony, 421 F.3d 742, 745-46 (C.C.P.A. 1970). This interpretation may be untenable. Any open claim may be construed to include some form of nonstatutory subject matter, because adding additional elements to subject matter meeting the limitations of the claim does not remove that subject matter from the scope of the claim. The Federal Circuit had the opportunity to resolve this question in In re Bilski, as one of the questions posed for en banc review was whether claims that contain both mental and physical steps are eligible subject matter under section 101. See Bilski, 264 F. App'x. 897 (Fed. Cir. 2008) (order granting en banc review). However, the court did not directly address this question in its en banc decision. See In re Bilski, 545 F.3d 943 (Fed. Cir. 2008).

77. See United States Patent and Trademark Office, Manual of Patent EXAMINING PROCEDURE $\S 2107.02$. (8th ed. rev. 6, 2007) ("Where an applicant has established utility for a species that falls within an identified genus of compounds, and presents a generic claim covering the genus, as a general matter, that claim should be treated as being sufficient under 35 U.S.C. $\S 101 . ")$.

78. The question becomes more complicated if some members of $x$ have utility, and some do not. Unlike novelty and nonobviousness - for which the claim is invalid if any species encompassed by the claim lacks those qualities-the utility requirement of section 101 still may be met even if some members of the set $x$ are not useful. At least in recent case law, this question of "inoperative embodiments" has been treated not as a matter of utility per se, but as a matter of compliance with the enablement requirement of section 112: so long as one of ordinary skill in the art can distinguish between the operative and inoperative embodiments without "undue experimentation," then one of skill in the art can "make and use" the invention in accordance with the first paragraph of 
Unlike sections 101, 102, and 103, the disclosure requirements of section 112 cannot be reduced to an inquiry defined strictly in terms of the laim scope. Consider the enablement aspect of section 112, which iccording to the reductionist position, is the only disclosure doctrine lecessary to define the proper scope of allowable claims. Section 112 frames the enablement inquiry as whether one of ordinary skill in the art zan "make and use" the invention, a standard which the Federal Circuit as explained requires that the ordinary artisan be able to make and use the nvention without "undue experimentation." Let us define as $y$ the set of Ill things which the skilled artisan, equipped with the teachings of the jatent and the knowledge of the art, could make and use without undue zxperimentation. We cannot express enablement as a simple intersection as we could for sections 101,102 , and 103 . Simply because an inventor as enabled something within the scope of the claims, he is not necessarily entitled to everything within the scope of the claims. The proposition:

The claim is enabled if $x$ and $y$ intersect

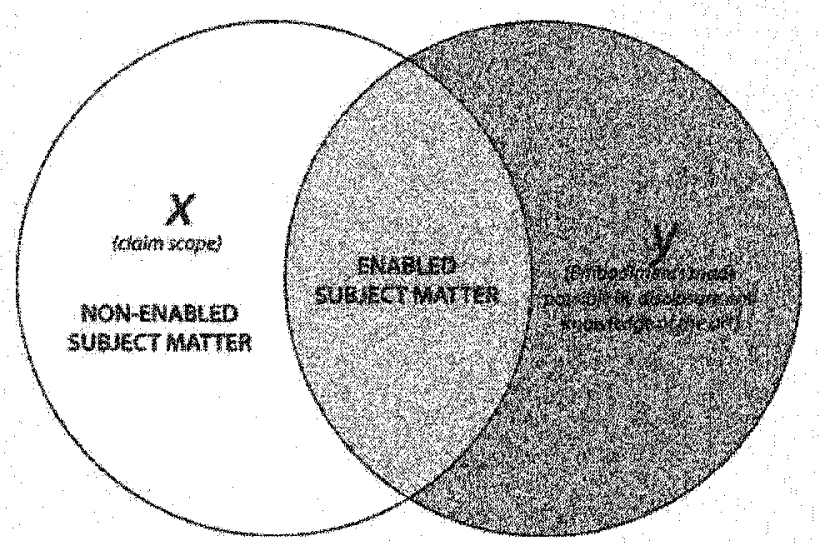

section 112. See Atlas Powder Co. v. E.I, du Pont de Nemours \& Co., 750 F.2d 1569, 1576-77 (Fed. Cir. 1984) (holding that claim encompassing inoperative embodiments may be enabled if one of ordinary skill can distinguish inoperative embodiments without undue experimentation). We might express this doctrine as follows:

Let $x^{\prime}$ be the members of $x$ which are operative, and let $x^{\prime \prime}$ be the members of $x$ which are not operative. The claim is valid if and only if one of ordinary skill in the art can identify members of $x$ without undue experimentation. 
is false, because enablement of some members of $x$ does not necessarily imply that the full claim scope is enabled. An inventor may very well disclose how to make and use some things within the scope of the claim, but still fail to enable the full scope of the claim. ${ }^{79}$ Nor must the inventor enable all things falling within the scope of the patent claim. The proposition

The claim is enabled only if all members of $\mathrm{x}$ are also members of $y$

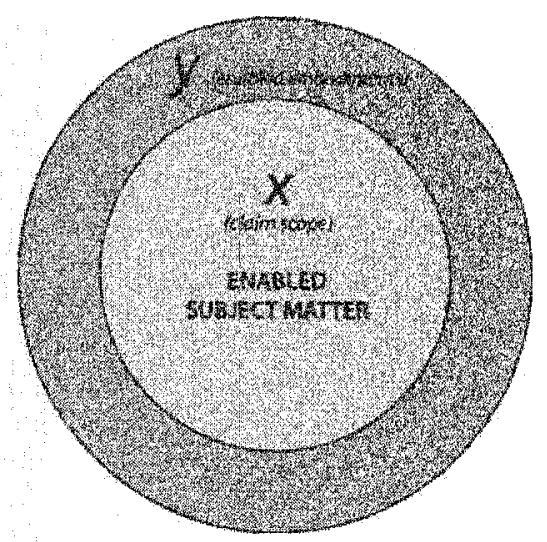

is false, because an inventor need not-and in most instances can not-enable all things falling within the scope of his claim. ${ }^{80}$

The point to emphasize is that the uncertainty inherent in the disclosure requirement of section 112 is qualitatively different from the uncertainties inherent in other doctrines of patent law. Once the predicate facts have been established, ${ }^{81}$ questions of infringement and novelty are completely determinate provided that the scope of the claims is precise. Nonobviousness is also determinate if, in addition to precise claim scope, we can determine whether a specific thing $y^{\prime}$ falling within the scope of the claims would or would not have been obvious to one of ordinary skill in the art. Not so for enablement. Even if we have a perfect technique for construing claims, and a perfect test of whether one of ordinary skill in the art could make and use a particular thing $y$, we cannot necessarily determine whether the claim meets the enablement requirement of section 112 . Validity has no certain relationship to claim scope even if the

79. See infra Section III.A.2.

80. See infra Section MI.A.1.

81. That is, whether the accused subject matter or the prior art actually has the properties recited by the claim. 
theory of claim construction or the underlying substantive doctrine of enablement is further refined.

Disclosure is therefore different from infringement, anticipation, or nonobviousness. Of what significance are these differences? The analysis of patent law as a formal system suggests two things about the disclosure doctrines necessary for a coherent system of patent law. First, if we aspire to a conceptually ordered system, the disclosure doctrines are going to be more troublesome than other aspects of patent law. Consequently, we might a priori be less confident that we can condense the problem of disclosure around a single unifying principle. Second, this analysis tells us something about the nature of the doctrines necessary to complete a coherent system of patent law. Doctrines like anticipation and enablement depend on the application of a legal standard to particular embodiments within the claim rather than the claim itself: anticipation asks whether a particular thing was known or used in the prior art, and enablement asks whether one of ordinary skill in the art could make and use a particular thing without undue experimentation. Because the problem of disclosure cannot be reduced to a simple inquiry in terms of embodiments falling within the claim, our disclosure doctrines may need to be founded in part upon a different intellectual framework - one that tests the scope of the claim itself against a legal standard, rather than one that tests a particular embodiment or collection of embodiments against a legal standard. This Article contends not only that the written description doctrine can fulfill this role, but also that the doctrine is absolutely necessary to complete the set of constraints on a coherent system of patent law. The next section therefore explores in depth why the enablement doctrine alone is insufficient to provide a coherent doctrine of permissible claim scope.

\section{THE LIMITS OF ENABLEMENT}

The inability to formulate a doctrine of enablement as a simple function of exclusion or inclusion is no mere quirk in the law of enablement. Rather, it is an inherent and necessary property of the particular claim system that has been at the heart of the United States patent system for a century, and more recently, abroad. It arises because we have consolidated three formerly separate concepts in patent law-the invention, the claim, and the scope of the inventor's exclusive rights-into a unitary conception founded upon the peripheral claim. The nature of the peripheral claim itself is what makes patent law not reducible to a simple set-theoretic system. In turn, the inability to reduce patent law to a simple set-theoretic system means that the attempt to squeeze out the last remnant 
of the pre-claim conception of patent law-the written description doctrine-cannot succeed if patent law is to be a coherent system.

\section{A. The Problem of Infinite Scope}

\section{All the World's a Genus: All Claims are Infinite}

Why is it that enablement alone cannot provide adequate limits of claim scope within the structure of modern patent law? It cannot because modern patent law must reconcile two apparently contradictory principles:

The claim completely and exclusively ${ }^{82}$ defines the class of things over which the inventor may exercise his rights.

All patent claims are of infinite scope.

The first principle is familiar; the second may be less so. It is an essential characteristic of all patent claims that they cover a set of entities rather than a single entity. Otherwise claims could not be infringed, save perhaps by the use of the one physical entity that the inventor constructed. Yet, the set of entities covered by a claim, despite being bounded by the language of the claim and the various doctrines of patent law, must be infinite in scope. This conclusion follows not from legal doctrine, but from the ontological nature of patent claims themselves.

The distinction between "genus" claims-claims covering a class of entities characterized by a common property-and "species" claimsclaims covering only a single entity-is familiar in chemical and biotechnological practice. An inventor might synthesize a novel molecule with antibiotic efficacy, and file a claim defining the specific structure of the molecule that she synthesized. However, because molecules with minor modifications to the chemical backbone may share the antibiotic efficacy, inventors typically also draft a claim to a genus of related molecules sharing the same backbone but varying in the atoms or groups attached to the backbone. Likewise, because multiple DNA molecules can encode the same polypeptide, ${ }^{83}$ an inventor discovering a novel protein will typically claim the genus of all DNA molecules encoding that protein. Chemical patent law has long recognized the problems of adequate

82. The doctrine of equivalents of course renders this statement not literally true if we take "define" to mean only the literal claim scope. The argument is the same whether we consider only the literal claim scope or literal claim scope plus equivalents; if the point is that all claims are infinite, then the extension of those claims by the doctrine of equivalents is a relatively trivial matter.

83. This is due to the degeneracy of the genetic code. 
disclosure that arise from a patentee's attempt to claim a genus that encompasses a variety of different but related molecules. ${ }^{84}$

Less evident is that essentially all patent claims-not just those defining chemical and biotechnological inventions-are genus claims. Modern patent claims define the scope of the inventor's rights by reciting properties; all things having those properties fall within the scope of a patent's claims. ${ }^{85}$ A claim to a molecule recites the atomic structure of the molecule, or the physical properties that characterize a composition of the molecule. A claim to an apparatus recites the structure of the components of the apparatus, or functional language describing its operation. A claim to a method or process recites the steps of the method, or the physical conditions under which the process take place. Regardless of form, however, most patent claims define an infinite number of existing and possible objects or acts. ${ }^{86}$ Consider a simple claim to a chair having four legs:

1. An object for supporting a human body, comprising

a substantially flat surface sized to accommodate a human

posterior, and

four legs supporting said surface.

This claim is unremarkable and, supposing the inventor to be the first to conceive of the idea of a chair with four legs, we would not think this claim poses any issue of adequate disclosure. Yet this claim, even more so than the typical chemistry or biotechnology claim, covers an infinite variety of embodiments. Like nearly all patent claims, this claim is written

84. See, e.g., Ridsdale Ellis, Patent Claims $\S \S 214-42$ (1949) (discussing problems of class definitions in chemical cases).

85. In metaphysical terms, the patent claim is thereby synonymous with the extension of the properties, or class: "A class is often thought of as the extension of a property (or concept), the collection of all those things ... which have that property or fall under that concept." A COMPANION TO METAPHYSICS 86 (Jaegwon Kim \& Ernest Sosa eds., 1996).

86. It might be possible in theory to draft claims limited to a particular instantiation of those properties. One might, for example, claim a chair with the property that "said chair being resident in Room 380 of 200 McAllister Street, San Francisco, on November 21, 2007." Obviously such claims have little commercial value, and are thus lacking in practice. This particular example raises the question of whether subject matter defined by temporal or spatial limitations would infringe if, having met those conditions at some point, ceased to meet them at a later point. The example is trivial but the general question is not. See Novartis Corp. v. Ben Venue Labs., Inc., 271 F.3d 1043, 1049 n.5 (Fed. Cir. 2001) (noting theory of transitory infringement by chemical intermediate). 
in the so-called "open" format, employing the word "comprising." 87 Such claims are construed to cover all things that possess the recited properties. Subject matter with additional properties or elements still falls within the scope of the claim, so long as it retains those properties recited by the claim. Thus chairs made of all sorts of materials, chairs of all sizes, chairs including contoured backrests, and chairs with roller wheels, etc. are all within the claim so long as they possess the recited flat surface and four legs. ${ }^{88}$ In reality, then there is no such thing as a "species" claim, for claims are never restricted to a single physical entity. Insofar as both genus and species are abstractions, the difference between the two is less in kind and more in degree.

Supposing the inventor to have disclosed the basic structure of the chair, we would have little difficulty concluding that claim 1 satisfies the enablement requirement of section 112. The inventor is entitled to assert exclusive rights over all chairs which include a flat surface and four legs. If the inventor has enabled those of skill in the art to make and use the genus of chairs defined by claim 1, then by definition, claims dependent on claim 1 -claims reciting additional properties and thereby defining subsets of claim 1 -are also enabled. ${ }^{89}$ Nonetheless the inventor has not disclosed information sufficient to make and use all subsets of claim 1 . Consider the claims:

2. The object of claim 1, wherein the legs and surface are composed of neutronium. ${ }^{90}$

3. The object of claim 1, wherein the object further comprises a portable fusion reactor.

87. There are more narrow patent claims drafted with the phrase "consisting of" instead of "comprising"; such "closed" claims extend only to subject matter possessing the recited elements and no others. Closed claims are quite rare and are generally employed only when the invention lies in the elimination of an element or step necessary in the prior art. Somewhat more common are "hybrid" claims employing the language "consisting essentially of," which are open to the addition of elements that do not materially change the properties of the claimed subject matter.

88. Indeed, chairs with five or more legs (but not three) would also fall within the scope of the claim, because they have the recited four legs in addition to their others. See Gillette Co. v. Energizer Holdings, 405 F.3d 1367, 1374 (Fed. Cir. 2005) (holding that four-bladed razor infringed claims reciting "a razor comprising ... a group of first, second, and third blades.").

89. See infra note 93.

90. A material of unimaginable density found only in neutron stars, where gravitation has forced protons and electrons to combine. 
Claim 2 defines a set of chairs composed of a material that cannot now (nor possibly ever) be made on this planet. ${ }^{91}$ Claim 3 defines a set of chairs including a portable fusion power source, a technology that might be possible in the future but certainly is not available today. Clearly, the inventor's disclosure did not enable one of ordinary skill in the art to make chairs of neutronium or including fusion reactors. Yet, because of the hierarchical structure of patent claims, the sets of chairs defined by claims 2 and 3 are subsets of the set of chairs defined by claim 1 .

These claims are, by statute, proper dependent claims because they incorporate the limitations of and add further limitations to define narrower subcategories of claim $1 .^{92}$ According to the hierarchical model of claim scope, if the inventor has satisfied the enablement requirement of section 112 with respect to claim 1, then he has done so for claims 2 and 3 as well. As the Board of Patent Appeals and Interferences reasoned in Ex parte Forstova:

We first express our concern about the anomalous situation confronting us where dependent claims $2-5$ are rejected as being non-enabled while claim 1 , the independent claim from which these claims directly or indirectly depend, is not rejected. It has long been held that a claim must be enabled throughout its scope. As a matter of logic, assuming claims 2-5 are proper dependent claims and we see no reason why they are not, the examiner's decision that claims 2-5 are non-enabled necessarily means that claim 1 is non-enabled. ${ }^{93}$

Thus, as a matter of enablement law, if one of ordinary skill in the art could make and use the set of chairs defined by claim 1, he can also make and use the smaller sets of chairs defined by claims 2 and 3 . Even if we accept the notion that the inventor need not enable all embodiments within

91. Claim 2 presumably would be a proper dependent claim even if claim 1 was written in closed format. Claim 3 would not, because the addition of a fusion reactor would be an additional element. Note that additional elements narrow claims. If we are truly committed to the hierarchical claim structure, it is not entirely clear that the distinction between open and closed claims can be sustained. Consider a closed claim defining a chair "consisting of a seat and four legs." From a purely ontological viewpoint, there is no distinction between narrowing the set by adding the property "composed of wood," and narrowing the set by adding the property "having a backrest." Yet the chair composed of wood would infringe the closed claim, and the chair including a backrest would not.

92. See 35 U.S.C. $\S 112$, 4 (2000).

93. Ex parte Forstova, No. 1998-0667, 2002 WL 323499923 (B.P.A.I. Apr. 11, 2002). 
the scope of a claim for the claim to be enabled, claims 2 and 3 are curious. It seems that either the inventor is entitled to claims 2 and 3, or there must be some limitation on permissible claim scope beyond the enablement doctrine as currently conceived. ${ }^{94}$

This paradox may be more significant than is first supposed. Today, the chair claim clearly lacks novelty over known chairs. However, claims 2 and 3 are certainly novel and nonobvious because no prior art discloses or makes obvious the limitations added by claims 2 and 3; claims 2 and 3 may therefore be patentable where claim 1 is not. A real-world manifestation of this pattern appeared in Amgen Inc. v. Hoechst Marion Roussel, Inc. ${ }^{95}$ Several of the patents in Amgen claimed a "non-naturally occurring erythropoietin [EPO] glycoprotein." Because naturally occurring EPO was known in the prior art, addition of the "non-naturally occurring" limitation made the claims novel and potentially nonobvious over the prior art. The patentee's disclosure of one method of making non-naturally occurring EPO was held to enable the claim. This claim was construed to cover all non-naturally occurring EPO, whether made by the patentee's synthetic process or not. By adding a novelty-imparting limitation to a broad genus, the patentee was able to lay claim to all subsequent synthetic EPO molecules without having to enable the sub-genera of molecules made by different synthetic processes. Although the broader claim is more useful commercially, as with claims 2 and 3 , it is difficult to understand in terms of enablement alone why Amgen could not have explicitly claimed synthetic methods of producing EPO that were not yet possible when it filed its application, given that the broader category of synthetic EPO was enabled. ${ }^{96}$

Likewise, in Forstova, the Board of Patent Appeals and Interferences reversed enablement rejections of claims on technology primarily useful

94. One might object that claims 2 and 3 lack utility as demanded by 35 U.S.C. $\S 101$. If utility means the requirement that inventions confer some tangible benefit upon society, then the lack of utility can easily be remedied by changing the hypothetical to less outlandish objects that might become more useful by being composed of neutronium or including fusion reactors; such objects, if possible to create, would confer benefit upon society. Likewise, if concern exists about the prohibition against inventions that violate known laws of physics, examples can be chosen that are beyond current technology yet are more plausible than the ones given.

95. 314 F.3d 1313 (Fed. Cir. 2003).

96. Claims defining subject matter very far afield from the embodiments the inventor created may allow the inventor to circumvent certain limitations on the licensing of patent claims. See Robin Jacob, Objectionable Narrowness of Claim, in PRINCIPLES OF PATENT LAw 1097 (Donald S. Chisum et al. eds., 2d ed. 2001). 
for gene therapy, notwithstanding that gene therapy is not yet clinically viable. In Forstova, dependent claims to a method of transferring DNA into a host cell with a "therapeutic effect" on an organism were allowed, despite the examiner's rejection that applications of the method to clinical gene therapy in humans were not enabled. Because the claims were not directed to clinical gene therapy per se, the Board held that alleged difficulties in clinical gene therapy did not preclude enablement of the claim. ${ }^{97}$ However, given the Board's reasoning that enablement of a narrower claim is logically predicated on enablement of the broader claim, a dependent claim explicitly directed to clinical gene therapy ought to have been enabled as well. If so, the attachment of "non-enabled limitations" to broader enabled claims provides a means to circumvent the rule that an inventor cannot claim an improvement or additional feature on a base technology if the base technology itself is not enabled. ${ }^{98}$ If the nonenabled base technology is attached as a limitation to a broader enabled claim, then the problem of enablement is circumvented.

The problem is not simply one of future technology, for the claim is infinite regardless of when its scope is assessed. As in Amgen, a concern exists with the problem of claim scope in the context of after-arising technology: a later inventor develops a marvelous new back-supporting chair, and we question whether the original inventor ought to be entitled to assert patent rights over chairs that did not exist or could not exist at the time the inventor filed for a patent. The inventor's entitlement to future developments is important in allocating the proper incentives for innovation between earlier and later inventors. ${ }^{99}$ However, the scope questions that arise in the context of after-arising technology are merely subsets of the more general problem of infinite claim scope. There are an infinite number of variations on the simple chair that can be constructed with contemporary technology, such as variations in material, proportions, and decoration, and are within the scope of the claim. It seems self-evident that without a coherent conception of claim scope with respect to presentday embodiments of the invention, we cannot hope to achieve a coherent

97. See Forstova, 2002 WL 32349992, at 4-5.

98. See Gould v. Hellwarth, 472 F.2d 1383, 1386 (C.C.P.A. 1973) (holding that improvement on laser could not be patented absent disclosure enabling construction of laser).

99. See, e.g., Arti K. Rai \& Rebecca S. Eisenberg, Bayh-Dole Reform and the Progress of Biomedicine, 66 LAW \& CONTEMP. PROBS. 289, 295-298 (2003) (discussing problems raised by broad upstream patents in biomedical field); Robert P. Merges \& Richard R. Nelson, On the Complex Economics of Patent Scope, 90 COLUM. L. REV. 839, 885-91 (1990) (criticizing broad upstream rights). 
conception of claim scope as applied to future embodiments of the invention. $^{100}$

\section{What is the "Full Scope" of Infinite Scope?}

Notwithstanding the issues raised by cases like Amgen or Forstova, the puzzle posed by claims 2 and 3 might be considered as merely a quirk in current enablement doctrine. Abandoning, or at least modifying, the hierarchical model of claim scope with respect to enablement could eliminate the paradox. By discarding the Aristotelian requirement that all characteristics possessed by the genus must also inhere in the sub-genus, we could permit an enabled independent claim to include non-enabled dependent claims. After all, "enablement" is a legal property of the claim, not a physical property of the entities encompassed within the claim, ${ }^{101}$

100. Professor Merges has argued that we do not ask whether the inventor has enabled the subject matter recited by claim "generally," but merely whether the inventor has enabled the embodiments known to be within the claim as of the filing date. See Robert P. Merges, Rent Control in the Patent District: Observations on the GradyAlexander Thesis, 78 VA. L. REV. 359, 379 n.73 (1992). However, the proposition that the inventor need not enable subject matter infeasible with current technology seems to reduce to the tautological proposition that the inventor need not enable technology that is not enabled. The idea that claim scope is fixed by enablement at the time of filing provides a tool to resolve cases in which the denotation of a word used in the claim expands over time. See Christopher A. Cotropia, After-Arising Technologies and Tailoring Patent Scope, 61 N.Y.U. ANN. SURV. AM. L. 151, 165-68 (2005); Kevin E. Collins, The Reach of Literal Claim Scope Into After-Arising Technology: On the Construction of Things and Meanings, CONN. L. REV. (forthcoming 2008). However, the principle seems of little use in cases that do not involve a change in meaning over time. See infra text accompanying notes 108-124. Nor (ipso facto) can it constrain the scope of claims only involving current technology. See infra text accompanying notes 134-141. Still further, such a rule leaves unanswered the question of the scope of the patentee's entitlement when future developments are known but not yet technologically possible. For example, in the Amgen case, the defendant's technology (homologous recombination of transcription control sequences into human cells) was "known" in some sense at the time of the invention, because similar techniques existed for microorganisms and the application of such techniques to mammalian cells was an eagerly desired advance. The Federal Circuit has suggested that "nascent" technology must be specifically enabled by the disclosure but technology farther in the future need not be. See Chiron Corp. v. Genentech, Inc., 363 F.3d 1247, 1254 (Fed. Cir. 2004) (leading to the peculiar result that, all other things being equal, a given disclosure "enables" more technology later in time than earlier); see also Collins supra (discussing Chiron, 363 F.3d 1247).

101. According to Bertrand Russell, the failure of Aristotle (or of Aristotle's expounders) to recognize the ontological distinction between individuals and classes led to disastrous consequences in philosophy and in number theory. BERTRAND RUSSELL, A History of Western PHILOSOPHY, AND ITS CONNECTION With POLITICAL and SOCIAL CirCumstances From the Earliest Times to the Present Day 198 (1945). 
and there is no reason to demand that legal properties follow the rules applicable to physical entities.

Unfortunately, while simply declaring claims 2 and 3 non-enabled might solve the fanciful paradox presented here, it would not solve the very real problems that arise when assessing claims that include, as all claims do, non-enabled subject matter. The difficulties with current enablement doctrine, even when exotic technologies are not at issue, are evident from the Federal Circuit's recent enablement jurisprudence. The court has held claims on fairly conventional technologies invalid for lack of enablement under section 112, holding that the disclosure must enable the "full scope" of the patent claims. ${ }^{102}$ The court has not defined "full scope," other than to indicate that section 112 requires "reasonable enablement," 103 and to suggest that failure to enable "a significant portion of the subject matter encompassed"104 by the claims renders the claims invalid under section 112. Due to the infinite scope of patent claims, a patentee certainly need not, and in most instances cannot, enable every embodiment falling within the "full scope" of the claims. For example, a patentee who discloses an operable industrial process may claim that process broadly, even though the patentee has not enabled commercially refined variants of the process within the scope of the claim. ${ }^{105}$ Though the Patent Office has recognized that not every embodiment within the scope of the claims must be enabled, ${ }^{106}$ it is not clear if the Federal

102. See Sitrick v. Dreamworks, LLC., 516 F.3d 993 (Fed. Cir. 2008); Pharm. Res., Inc. v. Roxane Labs., Inc., 253 F. App'x 26 (Fed. Cir. 2007); Auto. Techs. Int'l, Inc. v. BMW of N. Am., Inc., 501 F.3d 1274 (Fed. Cir. 2007); Liebel-Flarsheim Co. v. Medrad, Inc., 481 F.3d 1371 (Fed. Cir. 2007); AK Steel Corp. v. Sollac, 344 F.3d 1234, 1241 (Fed. Cir. 2003).

103. AK Steel, 344 F.3d at 1244.

104. Id. at 1245.

105. See CFMT, Inc. v. Yieldup Int'l Corp., 349 F.3d 1333, 1338-40 (Fed. Cir. 2003) (rejecting argument of invalidity based on extensive experimentation necessary to achieve commercial embodiment). But see Ormco Corp. v. Align Tech., Inc., 498 F.3d 1307,1319 (Fed. Cir. 2007) ("If an inventor attempts but fails to enable his invention in a commercial product that purports to be an embodiment of the patented invention, that is strong evidence that the patent specification lacks enablement."). CFMT seems to highlight the inadequacy of temporal arguments alone to resolve the enablement paradox. See supra note 100 . Were the experiments needed to optimize the drying step of the cleaning process in CFMT an "after-arising" or "nascent" technology? Only, it seems, if anything not known at the time of filing is considered after-arising.

106. See, e.g., Ex parte Breakefield, No. 2001-1686, 2002 WL 32346083, at 3-4 (B.P.A.I. Feb. 7, 2002) (holding claim enabled where skilled artisan could distinguish between enabled and non-enabled embodiments). 
Circuit's recent "full scope" jurisprudence recognizes this basic principle. $^{107}$

What is clear is that reconciliation of enablement doctrine with a formal conception of patent law is difficult, perhaps impossible, without resort to disclosure doctrines beyond enablement. As an illustration, consider the Federal Circuit's decision in AK Steel Corp. v. Sollac, ${ }^{108}$ the case that inaugurated the current "full scope of enablement" line of authority. The patents at issue in $A K$ Steel were compositions of matter: aluminum-coated stainless steel strips made by an improved process of hot-dipping the steel strips in a coating solution. ${ }^{109}$ Standard industry coating solutions, known as "Type 1" coatings, included about 10\% silicon. The inventors discovered that the inclusion of silicon inhibited the coating process. The patent specifications therefore stated that pure coating solutions with little or no silicon (known as "Type 2" coatings) were preferred for their invention. However, the patent issued with an

107. With respect to the "full scope" requirement, the court in AK Steel stated: That is not to say that the specification itself must necessarily describe how to make and use every possible variant of the claimed invention, for the artisan's knowledge of the prior art and routine experimentation can often fill gaps, interpolate between embodiments, and perhaps even extrapolate beyond the disclosed embodiments, depending on the predictability of the art.

AK Steel, 344 F.3d at 1244 (emphasis added). This language can be read to suggest that while the specification need not describe every embodiment within the scope of the claims, it must enable one of skill in the art to practice every embodiment within the scope of the claims without undue experimentation. Historically, case law been clear that the specification need not disclose every embodiment within the scope of the claims, but has usually done so in the context of whether one of skill in the art would have to experiment unduly to identify operable species within the claimed parameters. The question of whether each embodiment within the claims must be embodied within the claims has not been addressed directly, but a rigid requirement would run counter to the sentiments expressed in the historical case law. See, e.g., In re Angstadt, 537 F.2d 498 (C.C.P.A. 1976). Interestingly, such precedent essentially rejects the synonymy of the claimed invention and the scope of the inventor's legal rights. See id. at 504.

By calling the claimed "invention" the "scope of protection sought" the dissent obscures the problem and frustrates the intended operation of the patent system. Depriving inventors of claims which adequately protect them and limiting them to claims which practically invite appropriation of the invention while avoiding infringement inevitably has the effect of suppressing disclosure.

See also infra Part IV (discussing conflation of invention, claim, and legal right).

108. 344 F.3d 1234.

109. See id. at $1236-37$. 
independent claim that did not limit the amount of silicon the coating solution:

1. A ferrous base ferritic strip continuously hot dip coated with a coating metal, comprising:

2. ... the coating metal including aluminum or aluminum alloys ... ${ }^{110}$

as well as a dependent claim explicitly reciting coating solutions with substantial amounts of silicon:

3. The strip of claim 1 wherein the aluminum coating metal contains up to about $10 \%$ by weight silicon. ${ }^{111}$

Thus, the patent claimed, in an independent claim, a broad genus not defined by any particular silicon content, and in a dependent claim, a narrower genus that encompassed the "Type 1" coating explicitly advised against by the disclosure.

The patentee asserted the patent against a defendant whose stainless steel strips were coated with a solution containing about $8 \%$ silicon. ${ }^{113}$ In light of evidence that one of ordinary skill in the art could not practice the invention using a coating solution with about $10 \%$ silicon, the Federal Circuit held that both independent claim 1 and dependent claim 3 were invalid for lack of enablement. ${ }^{114}$

What is remarkable about $A K$ Steel is that its outcome was dictated by a formalist conception of patent law and of patent claim structure in particular. Consider the alternative courses the court could have taken. The Federal Circuit's own case law had long suggested that a claim encompassing "inoperative embodiments" would not be invalid for lack of enablement, so long as one of ordinary skill in the art could identify the

110. Hot Dip Aluminum Coated Chromium Alloy Steel, U.S. Patent No. 5,066,549 (filed Nov. 22, 1988).

111. Id.

112. In the infringement suit, both the district court and the Federal Circuit construed the dependent claim to include Type 1 coatings with substantial silicon. AK Steel, 344 F.3d at 1240-43. The Federal Circuit held that, despite the maxim that claims are to be construed in order to preserve their validity, the clear literal word of the claim, and the prosecution history of the ' 549 patent, demanded that the claim be construed to cover coating solutions with about $10 \%$ silicon.

113. Id. at 1238 .

114. Id. at 1245 . Other claims in the ' 549 patent were essentially parallel to claims 1 and 3 , and met the same fate. 
inoperative embodiments without undue experimentation. ${ }^{115}$ One of skill in the art would certainly not have to experiment unduly to exclude the high-silicon embodiments that fell within the claims, since the disclosure quite simply instructs him to avoid them. ${ }^{116}$ The court's opinion does not refer to the "inoperative embodiments" doctrine, perhaps with good reason. ${ }^{117}$ If enablement were the only disclosure requirement of section 112, then the logical conclusion of the "inoperative embodiments" doctrine would be that the patentee may draft a claim of the form:

1. Everything.

and have no difficulties with section 112 , so long as the specification directs one of skill in the art to confine himself to one or two embodiments enabled by the disclosure. ${ }^{118}$

The second alternative would have been to construe at least claim 1 to exclude high-silicon coatings, given that the specification explicitly disclaimed such embodiments. Such a construction would not only comport with the maxim that claims are interpreted in light of the specification, but would also avoid the invalidation of claim 1 for lack of enablement. Why did the court not choose this course? In part, a formalist "plain meaning" principle of interpretation drove the court's decision. The claim, which recited a coating containing "aluminum or aluminum alloys," had no language limiting the coating's silicon content. Notwithstanding the principle that claims ought to be construed to preserve their validity,

115. Atlas Powder Co. v. E.I. du Pont de Nemours \& Co., 750 F.2d 1569, 1576-77 (Fed. Cir. 1984); In re Cook, 439 F.2d 730, 735 (C.C.P.A. 1971).

116. See In re Vaeck, 947 F.2d 488, 496 (Fed. Cir. 1991) ("[T]he disclosure must adequately guide the art worker to determine, without undue experimentation, which species among all those encompassed by the claimed genus possess the disclosed utility.").

117. It also may be that the litigants did not argue the "inoperative embodiments" doctrine, as there is no mention of the doctrine in the district court's lengthy opinion. See AK Steel Corp. v. Sollac, 234 F. Supp. 2d 711 (S.D. Ohio 2002).

118. Of course, prior art also limits claim scope; see infra Part III.B. To be fair, the Atlas Powder doctrine could be read more narrowly. Atlas Powder states that "Of course, if the number of inoperative combinations becomes significant, and in effect forces one of ordinary skill in the art to experiment unduly in order to practice the claimed invention, the claims might indeed be invalid." Atlas Powder, 750 F.2d at 1576-77 (emphasis added). One could interpret this passage to mean that a large number of inoperative embodiments is equivalent to undue experimentation, even if one of skill in the art could easily identify and exclude the inoperative embodiments. 
the court would not apply that principle absent any lexical ambiguity in the claim language. ${ }^{119}$

However, the "plain meaning" argument was secondary to the decision in AK Steel. More important than the "plain language" principle was the Federal Circuit's focus on the hierarchical structure of patent claims. According to the court, claim 1 must encompass coatings with up to $10 \%$ silicon, because claim 3 , which depended from claim 1 , explicitly recited "up to about $10 \%$ silicon." In the court's view, because claim 3 depended from claim 1, claim 3 must define a sub-genus entirely contained within the scope of claim 1. Given that claim 3 clearly encompassed high-silicon coatings, the supra-genus defined by claim 1 must encompass them as well. ${ }^{120}$ This line of reasoning is predicated on a formal, hierarchical view of claim structure: every dependent claim, because it merely adds limitations to another claim, must constitute a sub-genus of its parent claim. The subject matter encompassed by every independent claim must therefore be a superset of the subject matter encompassed by its dependent claims.

Such a view of claim structure has an impeccable pedigree. It simply recapitulates Aristotle's scheme of categorization, in which all things that exist may be classified in a hierarchical structure of genus and subgenus. $^{121}$ It is not, however, required by the patent statutes. 35 U.S.C. $\S 112$ simply requires that dependent claims add a further limitation to subject matter already claimed and are construed to include all the limitations of the independent claim. ${ }^{122}$ It does not require that independent claims encompass all the subject matter defined by the dependent claim, nor does it require that any claim making reference to another claim be construed as a dependent claim. A priori, one could conceive of dependent claims that included all the limitations of an independent claim but whose subject matter was not entirely included within the independent claim, or one could conceive of claims that incorporate the limitations of other claims without being dependent on those claims. In fact, decisions of the PTO's Board of Patent Appeals and Interferences have considered the possibility that a claim referring to another claim might be treated as an independent claim, and that the

119. See AK Steel, 344 F.3d at 1243. See also MBO Labs., Inc. v. Becton, Dickinson \& Co., 474 F.3d 1323, 1332 (Fed. Cir. 2007) ("[V]alidity construction should be used as a last resort, not a first principle....").

120. AK Steel, 344 F.3d at 1242.

121. See infra Part IV.C.

122. 35 U.S.C. $\S 112, \Uparrow 4$ (2000). 
reference to another claim is only a shorthand form of drafting. ${ }^{123}$ Nonetheless, the Federal Circuit's intrinsic commitment to the hierarchical conception of claim structure foreclosed this route in AK Steel, leaving the court with no choice but to conclude that the independent claims encompassed the subject matter defined by the dependent claims.

After defining the patent's scope according to a formal conception of claim structure, the $A K$ Steel court proceeded to determine enablement of the claims, and it is at this point the uncomfortable interface between the formal structure of patent law and the enablement doctrine is apparent. ${ }^{124}$ The evidence showed that the patent's specification did not enable one of ordinary skill in the art to use high-silicon "Type 1" coating solutions in the manufacture of the claimed steel strips. Having construed the independent claims to encompass Type 1 coating solutions, the court held those claims invalid because "the specification [did] not enable a significant portion of the subject matter" claimed by the patent. ${ }^{125}$ Yet why were the Type 1 coatings a "significant portion" of the claimed subject matter? As we have seen, all claims are infinite. While there were an infinity of non-enabled Type 1 compositions within the scope of the claims, there were also an infinity of enabled Type 2 (low-silicon) compositions within the scope of the claims. It is not apparent why the first set ought to be more significant than the second, especially given that there were also an infinite number of non-enabled Type 2 compositions within the scope of the claims. ${ }^{126}$

Of course, the non-enablement of Type 1 embodiments was significant in $A K$ Steel because the accused infringer practiced a Type 1 embodiment. Nonetheless, whether the accused subject matter is enabled by the

123. See Ex parte Porter, 25 U.S.P.Q. (BNA) 2d 1144, 1147 (B.P.A.I. 1992); Ex parte Moelands, 3 U.S.P.Q. (BNA) 2d 1474, 1476-77 (B.P.A.I. 1987) (Spencer, J., dissenting in part, and Lovell, J., concurring in the result).

124. AK Steel could well have been a trivial case had it been resolved on written description grounds. The invention was described by the specification as employing lowsilicon coatings, not merely as a particular embodiment, but as a general property of the invention. Should the claims still be construed to define a genus of coatings without limitation to silicon content, they would not correspond with the specification's fixation of the invention within the definitional hierarchy. See infra Part IV.

125. AK Steel, 344 F.3d at 1245.

126. Consider, for example, Type 2 coatings dipped at extreme temperatures, or with immiscible materials. Of course, one of ordinary skill in the art would certainly know to avoid these embodiments. However, one of ordinary skill in the art would also know to avoid the Type 1 embodiments, given the specification's explicit teachings. 
disclosure is ostensibly irrelevant to the question of enablement; ${ }^{127}$ certainly under the formal conception of patent law, enablement is a function solely of the claim and the disclosure, and not dependent on whom the patentee sues. Perhaps the "full scope of enablement" doctrine can be expressed in terms of some calculus of infinities, in which the relative proportions of enabled and non-enabled subject matter are assessed. ${ }^{128}$ We might, for example, conclude the claim is enabled if one of ordinary skill in the art could practice some proportion of the embodiments falling within the claims. Nonetheless, since nearly all claims encompass non-enabled embodiments, the difficulty is in deciding which non-enabled embodiments are significant in the analysis. When claims recite particular numeric ranges, we tend to focus on whether the claimed subject matter functions with parameters lying along an axis defined by the range. In reality, however, all claims encompass subject matter defined by a very large number of axes, some explicit in the claim and some not, ${ }^{129}$ and it is difficult to label, a priori, one axis significant for enablement and another not. The answer given in AK Steel seems to be that embodiments practiced by the accused infringer are significant in the enablement inquiry. Nonetheless, if the answer to the question of significant characteristics is "those possessed by the accused subject matter" or "those brought to the court's attention," then it seems that we have abandoned the notion of a coherent system of patent law based on the peripheral claim. ${ }^{130}$ Indeed, if we conclude that the validity or scope of a patent depends on whom the patentee asserts it against, then we may have abandoned the conception of patents as objectively defined property rights altogether.

\section{B. Can Enablement Limit Claim Scope?}

The preceding section contended that, in light of the nature of patent claims, the enablement doctrine faces fundamental difficulties as a coherent or complete doctrine of patent scope. This section explores the

127. See, e.g., Durel Corp. v. Osram Sylvania Inc., 256 F.3d 1298, 1306 (Fed. Cir. 2001) ("The dispositive question of enablement does not turn on whether the accused product is enabled.").

128. Of course, if we discard the purely hierarchical view of enablement, cases like $A K$ Steel may become formally coherent; the independent claim may be enabled notwithstanding the existence of non-enabled dependent claims.

129. For example, a claim to an object encompasses a collection of things of varying size or material, while a claim to a process encompasses a collection of acts performed under various conditions such as temperature.

130. See infra note 268 for discussion of abandonment of the peripheral system. 
consequences of that deficiency for the permissible scope of patent claims and the structure of claiming itself. Its vehicle is to postulate a patent system that lacks additional disclosure doctrines such as written description. This section demonstrates that a patentee's entitlement is largely unbounded in such a system where enablement is the only disclosure doctrine limiting patent scope.

\section{Claim Scope Without Written Description}

The limits on a patent's scope essentially derive from only two sources: the prior art at the time of the invention, and the inventor's disclosure. ${ }^{131}$ If we take the reductionism of the formalist conception at face value, these limits can be embodied in only two doctrines: nonobviousness and enablement. The doctrine of nonobviousness embodies all the limitations imposed by the prior art because it functions as a superset of novelty. ${ }^{132}$ Enablement limits claim scope based on the inventor's disclosure; at least nominally, this limitation embodies the quid pro quo of the patent system that an inventor's exclusive rights be commensurate with the benefits conferred on society by his disclosure. ${ }^{133}$ At least since Lilly, however, the need for an additional disclosure doctrine to circumscribe claim scope, the "written description" aspect of section 112, has been contested. Subsidiary to this controversy has been the question of whether the written description requirement is confined to chemistry and biotechnology or is applicable to other arts as well.

The problem, I believe, can be boiled down to a very simple hypothetical devoid of reference to any particular technology. Suppose a patent applicant to file an essentially empty disclosure, with the following claim:

131. I assume for this discussion that there are no questions of subject matter eligibility or compliance with the technical requirements of the law.

132. There are some technical limitations to this principle. Subject matter which is in public use may anticipate a claim even if its existence or properties were unknown to those skilled in the art. Formally, such unknown subject matter might not be regarded as obvious. See, e.g., TorPharm, Inc. v. Ranbaxy Pharms., Inc., 336 F.3d 1322, 1327 (Fed. Cir. 2003) (discussing anticipation and obviousness in the absence of disclosure).

133. But see Holbrook, supra note 62, at 131-46 (arguing against disclosure function). 
4. All material objects which are enabled by the prior art, excluding those which are known or obvious in light of the prior art. $^{134}$

where "enabled" here means that the material object can be made and used without undue experimentation given the current state of the art. Ought the Patent Office allow this claim?

It seems self-evident that claim 4 ought not to be patentable. Still, explaining exactly why claim 4 runs afoul of the statutory requirements for patentability is not a trivial exercise. By its own terms, claim 4 only encompasses subject matter that is novel, nonobvious, and enabled as prescribed by statute. ${ }^{135}$ Therefore, insofar as the subject matter itself, there is no bar to the patentability of claim 4 if the doctrines of nonobviousness and enablement alone limit the scope of patent claims. If claim 4 is not patentable, it must be either that there is something impermissible about drafting a claim according to the fashion of claim 4, or that doctrines beyond nonobviousness and enablement are necessary to limit patent scope.

Claim 4's scope is admittedly limited, but it is not empty. Claim 4's scope is limited because most things obvious in light of the prior art are enabled by the prior art, and so claim 4 encompasses only the set of objects defined by the difference between the set of enabled objects and the set of obvious objects. If the standards of nonobviousness and enablement were symmetrical, then this difference would be the empty set and claim 4 would cover nothing. Any object that was enabled by the prior art would also be obvious in light of the prior art and hence unpatentable. However, the standards of enablement and nonobviousness are symmetrical neither in theory nor in practice. ${ }^{136}$ Most notably, the judicial

134. I limit these hypothetical claims to material objects for simplicity and to avoid issues of patentable subject matter under section 101, but the principles are applicable to claims for methods and other intangibles as well.

135. Of course much of the subject matter defined by claim 4 is not "useful" as required by section 101, but if one accepts definition by such concepts as "obvious" or "enabled" then it is little stretch to supplement the definition with "useful."

136. Before the notions of obviousness and enablement were clearly differentiated, the standard may have been more symmetrical. Writing in 1873, Curtis states that a specification will render the patent void if it "create[s] a necessity for the exercise of inventive power on the part of the person who has [undertaken] to apply the description." GEORGE T. CURTIS, A TREATISE ON THE LAW OF PATENTS FOR USEFUL INVENTIONS $§ 256$ (4th ed. 1873) (emphasis in original). The term "inventive power" suggests a cognitive aspect inherent in the modern doctrine of nonobviousness. However, Curtis's discussion 
standard for enablement, that the ordinary artisan ought to be able to make and use the invention without "undue experimentation," invokes the effort required to produce the invention given the state of the art. In contrast, the statutory standard for nonobviousness under section 103 explicitly discourages inquiry into the inventive effort, declaring that "[p]atentability shall not be negatived by the manner in which the invention [would be] made." 137 Therefore, if only the doctrines of enablement and nonobviousness constrain patent scope, claim 4 defines an actual slice of patentable subject matter.

One might object that claim 4 fails to satisfy the definiteness requirement of 35 U.S.C. $\S 112$, ๆ 2 . However, indefiniteness requires insoluble linguistic ambiguity, ${ }^{138}$ and under this standard the metes and bounds of claim 4 are clear. We cannot envision all the entities falling within the scope of claim 4 , nor can we recite all their characteristics, nor can we say with certainty at the present what future creations will fall within claim 4. This is true, however, of all patent claims, for all patent claims are infinite and cannot specify all of the characteristics of the subject matter that they encompass. If claim 4 is less indefinite than an ordinary claim, like the chair claim of claim 1, it cannot be because of the breadth of the claim or because particular subject matter falls within the claim. ${ }^{139}$ Indeed, to raise such arguments against claim 4 nearly negates the argument of indefiniteness. Arguments based on breadth are predicated upon a determination that something is within the scope of the claims, which in turn is predicated upon the ability to recognize that entities are or are not within the claim.

If claim 4 is indefinite, it must be because the properties recited by the claim - "material," "enabled," and "known or obvious"-are qualitatively different from the properties recited by claim 1, such that they fail to give an answer to the question of whether a particular entity falls within the claim or not. One of ordinary skill in the art could certainly decide whether putative subject matter is a material object or not; the objection must lie with the use of the properties "enabled" or "known or obvious."

Perhaps we have committed an ontological foul by including legal properties, rather than physical ones, as part the definition of subject

is mostly centered on undue experimentation as the standard for adequacy of the specification.

137. 35 U.S.C. $\S 103$ (a) (2000).

138. See text accompanying notes 31-32 supra.

139. See In re Fisher, 427 F.2d 833, 838 (C.C.P.A. 1970) (explaining that breadth of claim is irrelevant to indefiniteness). 
matter represented by claim 4 . However, it is difficult to see why such legal properties would render the claim indefinite. Both nonobviousness and enablement are factually premised on the judgment and ability of one of ordinary skill in the art. In the case of nonobviousness, whether the ordinary artisan would find the differences between the invention and the prior art obvious at the time the invention was made; in the case of enablement, whether the ordinary artisan could make and use the invention without undue experimentation. ${ }^{140}$ In deciding whether claim language is sufficiently definite to satisfy section 112 , $\mid 2$, we rely on the knowledge of one of skill in the art to assign meaning to claim terms otherwise indeterminate on their face. ${ }^{141}$ It would therefore be peculiar to conclude that one of ordinary skill in the art could not determine the metes and bounds of claim 4 because one of ordinary skill in the art could not assess whether subject matter is nonobvious or enabled, especially given that in patent litigation we entrust the determinations of nonobviousness and enablement to lay judges and juries.

We might instead conclude that claim 4 is indefinite not because there is something wrong with defining subject matter in terms of legal doctrines generally, but rather because the doctrines of nonobviousness and enablement are insufficiently refined to provide definitive answers to whether particular subject matter falls within claim 4 or not. Then, however, the objection to claim 4 is premised entirely on the uncertainty in our current doctrines of enablement and nonobviousness. If we posit readily ascertainable standards of enablement and nonobviousness, then it becomes untenable to argue that one of ordinary skill in the art cannot ascertain the scope of the claim. It is difficult to believe that all objections to claim 4 would disappear if the law of nonobviousness or enablement were more precise than it is today. Moreover, if the ultimate goal in demonstrating the unpatentability of claim 4 is to prove that patent law needs only the doctrines of nonobviousness and enablement to satisfactorily limit claim scope, then it seems a Pyrrhic victory to reach that conclusion on the grounds that the current doctrines of nonobviousness and enablement are hopelessly indeterminate.

140. To the extent that determining the bounds of claim 4 only requires a judgment about whether particular subject matter would be obvious or enabled to one of skill in the art, then the determination may be simpler than the determination of whether a claim is obvious or enabled.

141. See, e.g., Orthokinetics, Inc. v. Safety Travel Chairs, Inc., 806 F.2d 1565, 157576 (Fed. Cir. 1986) (stating that claim reciting "so dimensioned" is definite if one of ordinary skill in the art can obtain measurements). 


\section{The Relation Between Enablement and Nonobviousness}

Claim 4 shows us that, at least at the formal level, the doctrines of enablement and nonobviousness provide only incomplete limits on the scope of the patentee's claims. In particular, without additional disclosure requirements, there is no necessary relation between the inventor's disclosure and the scope of the rights granted to the inventor. What are the implications for patent law? The implications depend on how we respond to the problem posed by claim 4 . If we remain within our current system of defining the inventor's rights by peripheral claims, then it seems that there are three possible responses. The first is to simply concede that the patentee is entitled to the full scope of claim 4 . The second is to modify our doctrines of enablement or nonobviousness to eliminate the sliver of subject matter lying between the two doctrines. The third is to invoke an additional disclosure doctrine as a limitation on the scope of the patentee's rights.

The first response to the problem posed by claim 4 would be to declare that it is not a problem. No one files patent applications with empty disclosures, but claim 4 can be made more realistic by modifying it slightly. Suppose the applicant files an application with some disclosure, and the following claim:

5. All material objects which are enabled by the combination of my disclosure and the prior art, excluding those which are known or obvious in light of the prior art.

Claim 5 represents a more plausible situation than claim 4 , but does not resolve the question of scope: all things that were within the scope of claim 4 are also within the scope of claim 5 .

Still, claims 4 and 5 may not be problematic at all. One might argue that at any given point in time, all inventions that are enabled by current technology will be quickly disclosed, either by being claimed in another patent application or otherwise made known to the public. ${ }^{142}$ Therefore, the sliver of claimable subject matter lying in the gap between enabled and obvious subject matter will not exist in the absence of new information contributed by the inventor. On this view, since the standards of

142. This argument is similar to the one advanced by Judge Rader against the need for a separate written description doctrine. Judge Rader argued that inventions enabled by a technological advance at a particular point in time will inevitably be disclosed and claimed by some inventor in a patent application. See Univ. of Rochester v. G.D. Searle \& Co., Inc., 375 F.3d 1303, 1312 (Fed Cir. 2004) (Rader, J., dissenting from denial of rehearing en banc). 
enablement and nonobviousness evolve with advances in the art, the subject matter defined by the gap between them will remain insignificant. We will encounter problems only when decisions of the courts have legally cemented the standards of enablement or nonobviousness rather than let them flow with technological advance. For if legal fixation has significantly decoupled the standards of enablement and nonobviousness, then a minimal disclosure by an inventor may render a large swath of subject matter enabled but also nonobvious.

To illustrate, we might account for Lilly under this theory as follows. ${ }^{143}$ The development of a new general technology, recombinant DNA, opened the door to a large category of inventions based on the recovery of human genetic sequences, although the patent in Lilly was not one disclosing or claiming this general technology. Rather, making use of this new technology, the patentee in Lilly had isolated and disclosed a DNA molecule encoding rat insulin. In addition to claiming the rat insulin DNA, the patentee also claimed human insulin DNA, whose sequence was not yet known at the time of filing, and the broader genus of vertebrate insulin DNA molecules. Although enablement was not litigated in Lilly, it is arguable that under the prevailing standard, the isolation of human insulin DNA (or other vertebrate insulin DNA molecules) by sequence homology from the rat molecule would not have required undue experimentation and therefore was enabled. ${ }^{144}$ Thus, general technological advance had rendered the invention, along with many other human DNA molecules, enabled. The same technological advance should have rendered a correspondingly large swath of subject matter obvious. However, Federal Circuit precedent, particularly In re Deuel, suggested that because the prior art did not suggest the structure of the claimed molecule itself,

143. Professor Holman makes a similar point on the asymmetry of enablement and nonobviousness in his work on written description. See Holman, supra note 48, at 65-67. In the Lilly litigation, Lilly raised neither obviousness nor lack of enablement as grounds for invalidity. The rationale behind such a strategy is unclear from the judicial opinions of the case, although Lilly may have been reluctant to raise an enablement challenge: Lilly's argument that one of the patents at issue was anticipated rested on the premise that a disclosure of insulin polypeptide sequence in the prior art enabled one of skill in the art to make an insulin cDNA molecule. See Regents of Univ. of Cal. v. Eli Lilly \& Co., 39 U.S.P.Q. 2d (BNA) 1225 (S.D. Ind. 1995), aff'd in part, rev'd in part, Regents of Univ. of Cal. v. Eli Lilly \& Co., 119 F.3d 1559 (Fed. Cir. 1997).

144. Under In re Wands, routine screening of human cDNA library may have sufficed to retrieve a human insulin cDNA. In re Wands, 858 F.2d 731, 736 (Fed. Cir. 1988); see Arti K. Rai, Intellectual Property Rights in Biotechnology: Addressing New Technology, 34 WAKE FOREST L. REV. 827, 835 (1999). 
the claimed species of human insulin DNA would be nonobvious. ${ }^{145}$ Human insulin DNA was therefore, more by case law than by technology, within the zone of things enabled but not obvious in light of prior art. By decoupling the standard of nonobviousness from considerations such as the ease of obtaining the chemical entity, the Federal Circuit drew the boundaries of nonobviousness such that all of the incipient information about genetic sequences fell into the gap between enablement and obviousness. The invocation of the written description doctrine in Lilly, and subsequent tightening of the written description and utility standards by the courts or the Patent Office, has been an attempt to limit the subject matter otherwise made patentable by the artificial divergence of the enablement and nonobviousness standards. If the standards of enablement and nonobviousness were permitted to properly float with the advancement of the technological arts, there would be no need to invoke other doctrines to circumscribe claim scope. ${ }^{146}$

There are nonetheless significant difficulties with the argument that only in unusual circumstances will patentable subject matter lie in the gap between enablement and nonobviousness. For one, even if the standards of nonobviousness and enablement freely advance with the art, the scope of inventions defined by claim 4 is decidedly nontrivial. Consider patents on simple mechanical inventions. Such inventions, not involving any radical technological advance, have been enabled by the state of the art for years. Yet they were not made, presumably because they were not obvious. ${ }^{147}$ Likewise, there exist many inventions in which the inventive activity consists of recognizing a problem; once the problem is recognized, the solution is well within the technological capabilities of the art without further contribution from the inventor. ${ }^{148}$ Perhaps inventions that do not

145. See Holman, supra note 48 , at $65-66$. The genus claim might nonetheless have been obvious under Durel Corp. v. Osram Sylvania Inc., 256 F.3d 1298 (Fed. Cir. 2001) if the structure of at least some insulin polypeptides encoded by the claimed genus of DNA molecules was known.

146. Note, however, that under this account the patentee might not have been entitled to claim the rat insulin cDNA either, if the cDNA molecule encoding rat insulin was considered obvious over the known rat insulin polypeptide sequence. The account of Lilly relying on only enablement and nonobviousness would therefore have precluded the patenting of many, if not most, of the first-generation biotechnological inventions.

147. Of course, many inventions are not made because they are not perceived as worthwhile, though the recognition itself that an invention would in fact be worthwhile is a form of nonobviousness.

148. See, e.g., In re Sponnoble, 405 F.2d 578, 585 (C.C.P.A. 1969) ("It should not be necessary for this court to point out that a patentable invention may lie in the discovery of 
open up new technological possibilities ought not to be patentable. Justice Douglas argued in his concurrence in Great Atlantic \& Pacific Tea Co. v. Supermarket Equipment Corp. ${ }^{149}$ that the constitutional mandate to promote the useful arts demanded patents that "push[ed] back the frontiers of chemistry, physics, and the like," 150 rather than mere "gadgets," and the Supreme Court recently reminded us that Great $A \& P$ remains relevant to the law of nonobviousness. ${ }^{151}$ If we continue, however, to grant patents on inventions that are possible with current technology, we must preserve a zone of patentability between subject matter that is currently enabled and subject matter that is currently nonobvious. It follows that the standards of enablement and nonobviousness ought not to be perfectly symmetrical, and that prior inventors cannot be entitled a priori to all things enabled by their disclosures in combination with the prior art.

\section{Rethinking Enablement}

If we are not content to ignore the problems posed by claims such as claims 4 and 5, then we must either rethink enablement (and possibly nonobviousness as well), or turn to additional disclosure doctrines to limit claim scope. Before considering modifications to the enablement doctrine, it is worth re-emphasizing the conceptual problems of relying solely upon enablement as a doctrine of claim scope. The uncertainty inherent in determining whether one of ordinary skill in the art could make and use a particular thing without undue experimentation is unremarkable. The true uncertainty in enablement lies in the absence of a defined relationship between the question of whether one of ordinary skill in the art could make and use a particular thing, and the question of whether one of ordinary skill in the art could make and use the claimed invention. As noted above, the scope of the inventor's possible rights is not synonymous with the scope of things enabled by the inventor; not only is the boundary between enabled claim and non-enabled claim indeterminate in practice, but there is no defined relationship between the intellectual framework of

the source of a problem even though the remedy may be obvious once the source of the problem is identified.").

149. 340 U.S. 147 (1950).

150. Id. at 154-55 (Douglas, J., concurring). Of course, true discoveries in chemistry, physics, and the like would be unpatentable as natural laws; moreover, at the time the Constitution was drafted, one suspects the inventors of the young republic were more concerned with incremental improvements in agriculture or manufacturing than landmark scientific discoveries.

151. See KSR Int'l Co. v. Teleflex Inc., 127 S. Ct. 1727, 1739 (2007) (emphasizing that cases like Great $A \& P$ remain good law). 
the enablement inquiry (whether one of ordinary skill could make and use a thing) and the legal framework (whether one of ordinary skill could make and use the claimed invention). ${ }^{152}$ Such inquiries may or may not be commensurable, but our current difficulty in relating them would seem to make enablement, at least as now conceived, a fragile foundation on which to place the full burden of determining permissible claim scope. ${ }^{153}$

\section{Converging Enablement and Nonobviousness}

These considerations aside, can the doctrines of nonobviousness or enablement be modified to constrain a patentee's rights without resort to a doctrine like written description? If we think that claim 4 fairly represents the problem, that the standards of nonobviousness and enablement are not symmetric, then perhaps convergence of the two doctrines will solve our problems. ${ }^{154}$ The scope of claim 4 arises because the standards for enablement and nonobviousness are not symmetric. If the set of subject matter enabled by the prior art is the same as that made obvious by the prior art, then the scope of a claim like claim 4 is non-existent. ${ }^{155}$

Conceptually, enablement and nonobviousness seem difficult to merge. At least in theory, the doctrine of nonobviousness reserves for

152. See infra Part IV.C., on the distinction between thing and invention.

153. Amgen may be instructive here as well. Amgen Inc. v. Hoechst Marion Roussel, Inc., 314 F.3d 1313 (Fed. Cir. 2003). In Amgen, the patentee, who had been the first to synthesize human erythropoietin, asserted claims to essentially all synthetic erythropoietin molecules regardless of how they were synthesized. Had the patentee sought claims explicitly directed to "[a] method of producing synthetic EPO," the enablement requirement would likely have dictated that the claims be limited to the method of synthesis disclosed by the patentee. However, because the claims were drafted with a source limitation, "non-naturally occurring," rather than an explicit reference to the process of producing EPO, the claims were considered "composition" claims for which a patentee need disclose only a single method of making to claim the composition no matter how made. The point is not whether the patentee in Amgen deserved broad claims. The point is that the indeterminate relationship between claim scope and disclosure characteristic of the enablement doctrine makes the entire scope question highly sensitive to fine points of the law of enablement.

154. Professor Durham discusses a proposal to make infringement by equivalents symmetrical with nonobviousness. See generally Durham, supra note 75 . Because both the doctrine of equivalents and enablement are in some sense scope doctrines, some of Durham's analysis not tied to the particular concerns of nonliteral infringement might be invoked to support symmetrical standards of enablement and nonobviousness. See id. at 1013-19 (arguing that gauging scope of patentee's rights by nonobviousness comports with economic theories of patent law).

155. See also Holbrook, supra note 62, at 169-73 (arguing that standards of nonobviousness and enablement ought to converge on possession). 
patent protection those inventions which would not have been made at all or in a timely manner, absent the incentives provided by the future grant of the patent monopoly. Enablement (or any other scope doctrine) defines in the end what share of present economic activity over which the inventor may exercise exclusive rights. To be sure, more extensive claim scope provides larger incentives, but unless we believe inventors can perfectly forecast the future then there is no precise relationship between the current value of technology and the incentive necessary to bring that technology into being.

Notwithstanding teleological distinctions between the doctrines, we might start by defining obviousness in terms of enablement: All things enabled by the prior art are obvious. However, while this symmetry would eliminate the scope of claim 4 , it would also eliminate the category of inventions discussed above: the inventions which are feasible with current technology but have not yet been invented. Unless we are willing to exclude all such inventions from patentability, ${ }^{156}$ nonobviousness cannot be defined solely in terms of enablement. ${ }^{157}$

Perhaps we can instead define enablement in terms of obviousness: All things obvious from the prior art and the inventor's disclosure are enabled. On this formulation, the inventor is entitled to claim all things which are obvious from the combination of the prior art and his disclosure. Since things obvious from the prior art alone are unpatentable, the inventor's rights would be defined in terms of what we might call "marginal obviousness:" those things which were not obvious from the prior art alone, but are obvious once the inventor's disclosure is considered. ${ }^{158}$ This solution has considerable formal appeal. Though

156. A strictly utilitarian analysis might question whether we need to offer the patent incentive to things already enabled by the prior art. However, if we believe that the patent system, at least in part, functions to protect the investments needed to bring products to market even after a technological breakthrough has been achieved, then patent protection ought not to be refused solely on the grounds that the invention required no special technological advance. From a natural rights perspective, if an inventor has created an invention that would not exist at the present time but for his or her inventive power, then the entitlement to an exclusive right does not seem to depend on whether the invention required something we define as beyond the current skill in the art.

157. Such definition would also tend to complicate the nonobviousness inquiry; given how frequently such issues arise in patent procurement and litigation, this drawback is significant.

158. This is in part the approach advocated by Professor Feldman, though she does not label it as such. Professor Feldman proposes that, for instances in which the inventor did not disclose an accused embodiment but such an embodiment is information knowable at the time of the invention, the scope of the patentee's rights should depend on 
nonobviousness is subject to factual uncertainty, formulating enablement in terms of nonobviousness makes it possible to define permissible claim scope while avoiding the difficulty enablement ordinarily faces with infinite claims. The inventor would be entitled to a halo of subject matter surrounding his or her disclosure, the extent of that halo being determined by what is obvious or not based on the disclosure and the prior art. Under this formulation, the inventor is entitled to a claim akin to the following:

6. All material objects which are obvious in light of the combination of my disclosure and the prior art, excluding those which are known or obvious in light of the prior art.

With claim 6 , we have succeeded in defining a doctrine of claim scope that, while subject to factual uncertainty, is not subject to the conceptual uncertainty of current enablement doctrine. We have also succeeded in turning back the clock more than a century. What claim 6 defines is, in essence, a central claiming system, in which the inventor describes a core and the scope of his rights extends in a diminishing penumbra around the core. A quasi-central system, in fact, may be the only solution to the problems of scope raised by this Article. ${ }^{159}$ But if we wish to adhere to our peripheral claiming system, we must declare claim 6 to be indefinite under 35 U.S.C. $\S 112$, and encourage the inventor to draft peripheral claims that approximate claim 6 in scope. It is not certain whether claim 6 can be dismissed as indefinite: if one of ordinary skill in the art can recognize what is obvious and what is not obvious, then it appears that one of ordinary skill in the art can ascertain the boundaries of claim $6{ }^{160}$ If one of skill in the art cannot recognize what it is obvious and what is not, then patent law seems headed for some difficulties, given that it is the one of ordinary skill in the art who decides whether subject matter is obvious or not under 35 U.S.C. $\S 103 .{ }^{161}$

whether the step from the disclosure to the accused subject matter is routine or "requires creativity, imagination or experimentation to derive." Robin Feldman, The Inventor's Contribution, 9 UCLA J.L. \& TECH. 1, 35 (2005). She describes this inquiry as having "the indirect effect of measuring the inventive leap of the accused product." Id. at 39. Measuring the level of mental or inventive activity required to create something seems very firmly rooted in the nonobviousness inquiry, though here framed in terms of the inventor's disclosure rather than the prior art alone.

159. See infra Part IV.C.

160. See also supra text accompanying notes 139-142.

161. This conundrum may highlight the difficulty in employing the perspective of one of ordinary skill in the art, logically employed to make technological judgments such as nonobviousness, to decide essentially legal matters concerning the definition of the 
Formal questions of claim structure aside, defining permissible claim scope along the lines of claim 6 also carries significant policy implications. By its terms, claim 6 excludes from patent scope all technological developments occurring after the date of the invention, except those which are obvious in light of current technologies. Some commentators have advocated this result by proposing that the inventor's rights be fixed in terms of the state of the art at the time of the invention. ${ }^{162}$ However, while this limitation might seem appropriate for technologies following discontinuous patterns of technological improvement, ${ }^{163}$ it is more difficult to apply it to technologies characterized by continuous and cumulative development. For ordinary technologies, few would agree that any nonobvious improvement upon a patented invention should escape infringement altogether. But whether one regards this as the optimal result on policy grounds, aligning enablement and nonobviousness excludes future technologies from patent protection. ${ }^{164}$ To achieve a coherent scope doctrine within the confines of the peripheral claiming system, we must consider other modifications of the enablement doctrine or look beyond it altogether.

\section{2. "Enablement Plus"}

In fact, it is unnecessary to look further than current case law to find that such modifications to the enablement doctrine have already been made. Certain aspects of existing enablement law, while difficult to square with the nominal conception of enablement as a "make and use" requirement, can best be explained as responses to the problem of untethered claim scope epitomized by claim 4 . The underlying objection to

patentee's exclusive rights. In this light, one may question whether the notion that claims ought to be interpreted from the perspective of one of ordinary skill in the art is truly tenable.

162. See, e.g., Robin Feldman, Rethinking Rights in Biospace, 79 S. CALIF. L. REV. 1, 40-41 (2005). Alternatively, greater reliance on the doctrine of equivalents may provide coverage for future developments. See generally Cotropia, supra note 100.

163. Feldman proposes this rule in the context of "uncertain arts" such as biotechnology. Feldman, supra note 162, at $40-41$. The cases may be viewed as instances in which new technologies allowed the accomplishment of old results by radically different means. The true effect of "uncertainty" may be that technology proceeds erratically, with unpredictable leaps that open or revisit large areas of subject matter, and give new meanings to old words within the lifetime of a patent.

164. One might circumvent this difficulty by relying more heavily on the doctrine of equivalents to cover future developments. See, e.g., Holbrook, supra note 62, at 158. Ultimately heavier reliance on the doctrine of equivalents points towards abandonment of the peripheral claim system. 
claim 4, and to a lesser extent claims 5 and 6 , is not that the scope of protection conferred by those claims is not calibrated to the policy goals of patent law, but rather that the scope of the claim has little or nothing to do with what the inventor actually invented. ${ }^{165}$ Two aspects of enablement doctrine embody the requirement of a nexus to what the inventor actually made or disclosed, a consideration irrelevant to the question of whether one of ordinary skill in the art could make and use the invention without undue experimentation, but relevant to an underlying concern that the inventor be entitled to claim only that which he invented.

Consider the principle that if a feature described by the disclosure as critical for the invention is not recited in the claim, the claim is invalid for lack of enablement. ${ }^{166}$ Whether a feature described by the patentee as critical appears in the claim is not relevant to whether one of ordinary skill in the art could make or use the invention defined by the claim, but is relevant to the question of whether the claim is connected to what the inventor actually invented. This principle, though little applied in recent years, ${ }^{167}$ shows that current enablement doctrine incorporates limitations

165. If we are completely convinced by Kitch's prospect theory, we might assert that assigning the patent to the "true inventor" is not strictly necessary; what matters is the existence of the property right, not to whom it is initially assigned. Of course, the longterm effects of denying patents to those who create would be corrosive if we believe that creation is motivated by the hope of a patent. Moreover, the patent and copyright clause of the Constitution gives Congress the power to grant exclusive rights to "inventors," thereby restricting exercise of power under the clause to actual inventors. In this light one might imagine that claim 4 could be invalid under 35 U.S.C. $\S 102(f)$, which denies patentability if the inventor "did not himself invent the subject matter sought to be patented." However, section 102(f) requires that the claimed invention be derived from someone else. See, e.g., Oddzon Prods., Inc. v. Just Toys, Inc., 122 F.3d 1396, 1401-02 (Fed. Cir. 1997) (explaining that section 102(f) renders invalid claims in which named inventor derived invention from another).

166. See In re Mayhew, 527 F.2d 1229, 1233 (C.C.P.A. 1976).

167. No subsequent majority opinion of the Court of Customs and Patent Appeals or the Federal Circuit has relied upon Mayhew. However, the Mayhew principle remains enshrined in the MPEP $[\$ 2164.08(\mathrm{c})]$, and the PTO and the Board of Patent Appeals and Interferences have relied upon Mayhew to reject claims failing to recite elements described by the inventor as essential. See, e.g., Ex parte Araki, No. 2003-1926, 2004 WL 4979022 (B.P.A.I. Mar. 2, 2004); Ex parte Zacharias, No. 2002-0741, 2002 WL 32346094 (B.P.A.I. Nov. 6, 2002). Arguably, Mayhew has been misinterpreted; the specification's emphasis on the omitted feature may only have been evidence tending to show that the broader claim lacking the feature was not enabled. 
on claim scope beyond the requirement that the disclosure teach how to make and use the invention without undue experimentation. ${ }^{168}$

More recently, the Federal Circuit has held that the novel aspect of a claimed invention must be enabled by a specific disclosure in the specification, rather than by resort to the knowledge of one skilled in the art. In Automotive Technologies International, Inc. v. BMW of North America, Inc., ${ }^{169}$ the Federal Circuit found enablement lacking because the patent's specification disclosed only mechanical side impact sensors, and not electronic side sensors. Dismissing the patentee's argument that the knowledge of one skilled in the art could supply the information required to construct electronic side sensors, the court held that "[i]t is the specification, not the knowledge of one skilled in the art, that must supply the novel aspects of an invention in order to constitute adequate enablement." 170 Under the formal model of patent scope, in which the claim limitations define the category of subject matter to which the patentee is entitled, the "novel aspects" of the invention have no significance for enablement. Either the specification enables one of ordinary skill in the art to make and use the subject matter defined by the claim limitations, or it does not; the question of which aspects of the invention are novel is only relevant to novelty and nonobviousness.

168. Judge Baldwin of the Court of Customs and Patent Appeals, concurring in Mayhew, regarded the case not as a failure to meet the enablement requirement of section $112, \uparrow 1$, but as a failure to meet the requirement of $\uparrow 2$ that the claims define what "the applicant regards as his invention," that is, a connection between the claim and the inventor's subjective view of the invention. Mayhew, 527 F.2d at 1237-39 (Baldwin, J., concurring). For those critics of the written description doctrine who object that the doctrine lacks statutory foundation, the requirement that claims correspond to what the inventor regards as his invention would seem to provide more than adequate basis. However, the Court of Customs and Patent Appeals, with considerable internal debate, seems to have established that whether the claims define what the inventor regards as his invention is a subjective question, answerable only by extrinsic evidence of the inventor's intent, and not the specification. See In re Ehhreich, 590 F.2d 902, 906-07 (C.C.P.A 1979); id. at 910 (Baldwin, J., concurring); In re Cormany, 476 F.2d 998, 1002-03 (C.C.P.A. 1973) (Baldwin, J., concurring, and Lane, J., concurring); In re Prater, 415 F.2d 1393 (C.C.P.A. 1969). The Federal Circuit, no doubt reluctant to endorse a validity doctrine dependent on the inventor's subjective view of his invention, has attempted to confine doctrine by the somewhat implausible notion that the statutory requirement is applicable only during prosecution but not in infringement litigation. See Solomon v. Kimberly-Clark Corp., 216 F.3d 1372, $1377-79$ (Fed. Cir. 2000).

169. Auto. Techs. Int'l, Inc. v. BMW of N. Am., Inc., 501 F.3d 1274 (Fed. Cir. 2007).

170. Id. at 1283 (quoting Genentech, Inc. v. Novo Nordisk A/S, 108 F.3d 1361, 1366 (Fed. Cir. 1997)). 
These aspects of enablement law cannot be explained in terms of a doctrine that entitles an inventor to claim everything that his specification permits one of ordinary skill in the art to make and use without undue experimentation. ${ }^{171}$ They can only be explained by a doctrine that limits the inventor's rights to subject matter he actually invented, or the subject matter described in the disclosure. The $B M W$ doctrine resolves the problem posed by claims like claim 4: because the novel and nonobvious subject matter falling within the scope of the claim does not appear in the (empty) disclosure, the claim would not meet the enablement requirement.

Thus the difficulties in formulating a complete system of patent law in terms of formal axioms are more than theoretical concerns. The underlying inability of the "make and use" inquiry to satisfactorily constrain claim scope has already shaped enablement law. The question, therefore, is not whether a disclosure requirement beyond "make and use" is necessary, but whether such a requirement fits better in the law of enablement or the law of written description. The $B M W$ opinion emerged from the Federal Circuit without outward controversy, presumably because it framed the requirement for disclosure in terms of enablement rather than written description. ${ }^{172}$ A requirement that claimed subject matter be explicitly disclosed in the specification seems to be nothing more than written description masquerading under another name. ${ }^{173}$ It makes little sense to

171. That particular features of the invention are essential or novel might be evidence relevant to enablement. For example, the fact that a particular feature was not known in the prior art might be relevant to the question of whether one of ordinary skill in the art could implement that feature without undue experimentation. However, if a skilled artisan could have easily implemented a novel feature, a premise frequently invoked in the law of nonobviousness, then the novelty of the feature would be immaterial.

172. The panel of the Federal Circuit that decided $B M W$ included Judge Lourie, the most vocal proponent of applying the written description requirement to originally-filed claims, and Judge Rader, its most ardent opponent. The district court had held certain of the claims invalid under written description as well. The Federal Circuit took great pains to avoid having to decide the written description issue, which no doubt would have fractured the panel's unanimity. Id. at 1281-82 notes 1-2.

173. In the context of a written description priority determination, the Federal Circuit in Vas-Cath denied that the "novel or important" aspects of the invention held any special significance. Vas-Cath Inc. v. Mahurkar, 935 F.2d 1555, 1565 (Fed. Cir. 1991). But the court's point was that the written description must describe the claimed invention, not the novel or essential aspects in particular. See id. (" 'The invention' is defined by the claims on appeal."). One presumes if the inventor has sufficiently described the claimed invention, novel or essential aspects of the claims appear as a matter of course. See also Cooper Cameron Corp. v. Kvaerner Oilfield Prods., Inc., 291 F.3d 1317, 1323 (Fed. Cir. 2002) (explaining that written description does not require claims be limited to what inventor considers essential elements of invention). 
lodge in the law of enablement a requirement that the claims correspond to the invention described by the specification. To do so would distort and confuse the law of enablement, by grafting upon it an inquiry unrelated to the core notion of whether one of ordinary skill in the art could make and use the invention. The doctrine of written description already centers on the question of whether the invention defined by the claim corresponds with the invention described in the specification. Let us therefore turn to the written description requirement to see if it can provide the limits that enablement cannot.

\section{WRITTEN DESCRIPTION REVISITED}

\section{A. What Written Description is Not}

\section{Written Description as Possession}

Much of the confusion about the written description doctrine derives from its unfortunate formulation as "possession of the invention." 174 VasCath Inc. v. Mahurkar, a case dealing with priority issues, provides a canonical statement of the doctrine for those who disfavor applying the doctrine to originally filed claims:

The purpose of the "written description" requirement is broader than to merely explain how to "make and use"; the applicant must also convey with reasonable clarity to those skilled in the art that, as of the filing date sought, he or she was in possession of the invention. The invention is, for purposes of the "written description" inquiry, whatever is now claimed. ${ }^{175}$

Expressing the written description doctrine in terms of "possession" may have been sensible in the early stages of American patent law. Prior

174. Professor Holbrook has suggested an entirely different view of possession than the one currently embodied in written description doctrine and identifies possession of the invention as the central touchstone of patent law. See Holbrook, supra note 62. In Holbrook's structure, rather than possession being the predicate for adequate disclosure, enablement is instead the predicate or best evidence of possession: if the inventor has physically created the invention or provided an enabling description of how to do so, possession of the invention has been proven. See id. at 147. Accordingly, there is no need to lodge a separate possession requirement in the doctrine of written description, where it has previously resided. Holbrook is correct, I think, to argue that it makes little sense to characterize possession of the invention as a written description matter. Depending on exactly what is meant by possession, a disclosure that enables the invention may indeed be the best way to demonstrate possession. We are still left, however, with the question of what it means to enable the infinite genus we call "the invention."

175. Vas-Cath, 935 F.2d at 1563-64. 
to the full development of the peripheral claiming system, claims were not entities that defined a category of subject matter by listing its properties. Rather, claims were drawn directly to the inventive principle itself, and established not the inventor's right to exclude, but his right to the grant of a patent. ${ }^{176}$ Even after claiming assumed primary importance, "the invention" and "the claims" were distinct concepts in American patent law. ${ }^{177}$ One could discuss "the invention" in terms of the inventor's physical or mental creation, entirely apart from the question of the scope of the inventor's legal rights. Under such a regime, questions of whether the inventor physically possessed an embodiment of the invention, or whether the inventor mentally possessed the idea behind the invention, are sensible questions. But once the concepts of "invention" and "claim" became essentially synonymous in patent law, the notion of "possessing the invention" became a logical impossibility except as a rephrasing of the ultimate legal conclusion.

The expression of the written description requirement as a "possession" test is a relatively recent development, rooted in decisions of the Court of Customs and Patent Appeals that distinguished written description as a separate disclosure requirement in section 112 of the current patent statutes. ${ }^{178}$ However, possession cannot by itself serve as a coherent expression of the written description doctrine unless we are to take a very literal view of possession: that the inventor possesses only those physical entities he actually created, or exactly described in the specification.

Take Vas-Cath as an example. The patentee filed a design patent depicting a new design of a double-lumen catheter before filing a utility patent claiming the catheter. The claims of the utility patent recited a catheter with a narrowed end, having a diameter between $50 \%$ and $100 \%$ of the remainder of the catheter. Because of a question of intervening prior

176. For example, in a case like Vas-Cath, the invention might have been defined as something like forming the inner lumen 50 to $100 \%$ of the diameter of the outer lumen.

177. See infra Part IV.C.

178. See In re Smith, 481 F.2d 910, 915 (C.C.P.A. 1973) ("The specification as a whole conveys possession of the claimed invention as of the filing date."). Before that time, the notion of possession more frequently described whether the public had received the benefit of the invention, either through the disclosure of the prior art or the patentee's disclosure. See, e.g., Evans v. Eaton, 20 U.S. 356, 400 (1822) (object of the specification is to "put the public in possession of the invention"); In re Arkley, 455 F.2d 586, 590 (C.C.P.A. 1972) (Baldwin, J., concurring) (citing cases stating that the standard of anticipation is whether public was in possession of the invention). 
art, ${ }^{179}$ the patentee had to establish that the utility application was entitled to claim priority from the design patent, meaning that the design patent had to satisfy the written description requirement with respect to the invention defined by the claims of the later-filed utility patent. The Federal Circuit framed the question in terms of whether the drawings showed possession of the invention defined by the claims:

[T] he proper test is whether the drawings conveyed with reasonable clarity to those of ordinary skill that [the patentee] had in fact invented the catheter recited in those claims, having (among several other limitations) a return lumen diameter substantially less than 1.0 but substantially greater than 0.5 times the diameter of the combined lumens. ${ }^{180}$

Exactly what did the patentee possess or invent? The invention is what is claimed. The claims defined a genus of catheters, with an infinite variety of measurements and materials. The genus is constrained by the ratio of diameters defined by the claims, but like all patent claims it is an infinite genus. One could perhaps decide whether the patentee's drawings enabled a person of ordinary skill in the art to make and use the genus of catheters, but is it meaningful to ask whether the patentee "possessed" the genus? ${ }^{181}$

The question of "possession of the invention" is simply not a meaningful inquiry under our current claiming system. In the peripheral claiming system, "the invention" is a bundle of properties recited by the claims, defining the perimeter of the patentee's legal right to exclude. It is not syntactically sensible to ask whether an inventor "invented" or "possessed" an abstract bundle of properties defining a legally cognizable right. Inventors create ideas and things, not abstract legal entities or infinite sets of subject matter. ${ }^{182}$ One can of course make the ultimate

179. Which was the patentee's own Canadian design patent.

180. Vas-Cath, 935 F.2d at 1566.

181. The problem did not arise when possession was used in the context of anticipation, because a claim is anticipated if even a single species can be shown to have been described in the prior art. The Federal Circuit in Vas-Cath, referring to Court of Customs and Patent Appeals precedent, noted the disconnect between the concept of disclosure in anticipation and in sufficiency of a specification. See id. at 1562 (citing In re Lukach, 442 F.2d 967 (C.C.P.A. 1971)). The Lukach court noted that "[t]he matter of what language constitutes sufficient description to support a claim of given breadth has been a troublesome question." Lukach, 442 F.2d at 969.

182. Judge Giles Rich, the author of the Vas-Cath opinion, recognized the disconnection between what the inventor actually did and the legal conception of the invention as defined by the claims: "Claims are frequently a far cry from what the 
legal determination that the inventor "invented" or "possessed" the abstract rights defined by the claim, but one cannot ask the question as a factual premise to that ultimate legal determination.

\section{Written Description as a Priority Doctrine Only}

The other major misconception about the written description doctrine is that it is a novel doctrine, or that only since Lilly has the written description doctrine been understood to limit the scope of originally-filed claims. According to this view, the Court of Customs and Patent Appeals first invoked a separate "written description" doctrine in In re Ruschig in 1967 , to prevent a patent applicant from adding "new matter" to a patent application in the form of amended claims to an earlier-filed patent application. ${ }^{183}$ Because originally filed claims constitute their own description, written description "simply has no application to claims without priority problems," "184 and Lilly deviated sharply from established custom by applying the doctrine to originally-filed claims.

The idea that the disclosure limits claims, independently of the enablement requirement, was not invented by the Federal Circuit in Lilly in 1997 or by the Court of Customs and Patent Appeals in 1967 in Ruschig. In William Robinson's monumental and influential 1890 treatise on patent law, Robinson distinguished between the description of the invention and the disclosure of how to make and use the invention:

According to the statutes, the Description must contain full explanations of three different subjects: the invention itself; the manner of making it; and the mode of putting it into practical use, - a complete knowledge upon all these points being

inventor invented. In a suit, claims are construed to find out what the patentee can exclude the defendant from doing. CLAIMS ARE CONSTRUED TO DETERMINE THE SCOPE OF THE RIGHT TO EXCLUDE, regardless of what the inventor invented." Janice M. Mueller, A Rich Legacy, 14 BERKELEY TECH. L.J. 895, 899 (1999) (quoting an e-mail from Judge Giles Rich); see also Holbrook, supra note 62, at 146 ("The invention is not necessarily a particular embodiment necessarily but more the idea of the invention.").

183. See, e.g., Enzo Biochem, Inc. v. Gen-Probe Inc., 323 F.3d 956, 977-78 (Fed. Cir. 2002) (Rader, J., dissenting from denial of rehearing en banc) ("In 1967, in In re Ruschig, this court's predecessor created for the first time a new WD doctrine to enforce priority.") (citation omitted).

184. Id. at $979-80$ ("In 1997 , for the first time, this court purported to apply WD as a general disclosure doctrine in place of enablement, rather than as a priority doctrine.") (citing Regents of the Univ. of Cal. v. Lilly, 119 F.3d 1559 (Fed. Cir. 1997)). 
necessary to render the invention available to the public without further experiment or exercise of inventive skill. ${ }^{185}$

One commentator has argued that this passage merely expresses the modern doctrine of enablement (i.e., how to make and use the invention). ${ }^{186}$ While that interpretation might be plausible from the isolated passage, it is difficult to sustain in context. Robinson includes in the description of "the invention itself," information not necessary to make and use the invention, ${ }^{187}$ and elsewhere distinguishes between a description of the "intrinsic character" of the invention and a description necessary to practice the invention. ${ }^{188}$

Although the notion of defining the invention by the disclosure originated when American patent law did not require claims, the written description requirement is not an obsolete relic of the time before claiming. Robinson was writing at a time when claims were not only required by the Act of 1870 but had long been common practice. The notion that claims were distinct from the disclosure, and defined the boundaries of the patentee's legal rights, was well-developed and

185. William C. Robinson, The Law of Patents for Useful Inventions $§ 484$ (1890) (emphases added). The mode of making the invention and putting it into practical use was the inventor's best mode. See id. $\S 485$ (mode of making the invention "must be the best one known to the inventor"); id. $\S 486$ ("The mode explained must be the best within the knowledge of the applicant. ..."). As compared to section 112 of the current patent statute, the Act of 1870 differed primarily by requiring that "in case of a machine, [the inventor] shall explain the principle thereof, and the best mode in which he has contemplated applying that principle so as to distinguish it from other inventions. ..." Patent Act of 1870, ch. 230, 16 Stat. 198, 201 (repealed 1952).

186. See Janis, supra note 49, at 63-64 n.31 (2000). Professor Janis criticized reliance on the quoted passage to support an independent written description requirement by the court in In re Barker, 559 F.2d 588, 592 n.5 (C.C.P.A. 1977).

187. For example, Robinson believes that the inventor must describe the state of the prior art and how the invention differs from the prior art. ROBINSON, supra note 185 at $\S 484$.

188. See id. $\S 487$ ("The sole object of the Description is to confer knowledge upon the public concerning the intrinsic character of the new device or process and the mode of making it available in practice. ..."). In fairness, Robinson was not always consistent; in one passage he sequentially states the test of a complete description as a thoroughly metaphysical inquiry (whether it "embraces every essential part and attribute of the thing described") and then as a practical inquiry (whether "a person skilled in the art could make and use the invention."). Id. $\S 491$. The metaphysical foundations of Robinson's system are a fascinating topic in their own right. 
abundantly attested by Robinson and other treatise-writers. ${ }^{189}$ Robinson recognized that the claim defined the inventor's legal right, but also asserted that claims could not embrace subject matter not described by the specification, even if such subject matter was within the knowledge of one skilled in the art:

Features of the invention not delineated in the Description cannot be inserted in the Claim, even though a mechanic in endeavoring to construct or employ the invention would inevitably discover them. ${ }^{190}$

So the notion that claim limitations must be supported by the written description, notwithstanding the ability of one skilled in the art to make and use an invention with the claimed limitations, was certainly held by one of the most influential of all patent law scholars well after the development of the claim system.

Even if an independent written description requirement germinated only in 1967, it hardly has a less-esteemed pedigree than our modern enablement doctrine. The doctrine of enablement, in the sense of a requirement of section 112 that the disclosure teach how to make and use the claimed invention without undue experimentation, was itself created by the Court of Customs and Patent Appeals contemporaneously with its articulation of the written description requirement. Prior to that time, Patent Office practice was to issue "undue breadth" rejections that encompassed what we would now term enablement, written description,

189. A caveat to this argument is that omnibus claims, claiming the invention "substantially as described" in the disclosure, were still permissible, though the practice of claiming by essential properties was established by this time. Id. $\S 511$.

190. Id. $\S 515$. Robinson may not have been on the firmest ground for this statement. He cites as authority Needham v. Washburn, 17 F. Cas. 1276 (C.C.D. Mass. 1874) (No. 10,082), and Kelleher v. Darling, 14 F. Cas. 223 (C.C.D. Me. 1878) (No. 7,653). Kelleher concerned new matter in a reissue, though the court did reason by analogy that a claim reciting that feature in the original patent would have been invalid for failure to comply with the written description statute, notwithstanding the ability of one skilled in the art to discover the feature. Kelleher, 14 F. Cas. at 228. Needham did concern an original claim, and the court stated: "Much reason exists for holding, that the second feature of the claim is invalid, because not embraced in the description of the method or process used by the complainant, as required by the act of congress. ..." Needham, 17 F. Cas at 1278 . But the court declined to rest its holding entirely on that ground, because the claimed feature was the omission of a welding flux employed by the prior art process. Id. Both cases were decided by Justice Clifford riding the First Circuit. But the point is not whether Robinson's assertion was decisively settled law at the time; the point is that a notion of a description requirement beyond enablement and applicable to original claims was current. 
and indefiniteness rejections; ${ }^{191}$ only starting in about 1970 did the Court of Customs and Patent Appeals begin rigorously distinguishing the separate aspects of section 112 that we recognize today. ${ }^{192}$ Thus, strictly speaking, our modern doctrines of enablement and written description were both crystallized from the undifferentiated mass of "undue breadth" at the same time. Certainly the requirement that the patent's disclosure teach how to make and use the invention has long been central to patent law; it is nonetheless mistaken to say for purposes of interpreting our current patent statute that the written description doctrine is an abnormally novel development.

If Lilly was the first modern case to articulate a doctrine of written description applicable to originally-filed claims, it was not necessarily a radical innovation. Commentary contemporary with Lilly describes the alternative priority-policing function of written description inclusively rather than exclusively. ${ }^{193}$ Moreover, certain pre-Lilly Federal Circuit

191. See Paul M. Janicke, Patent Disclosure-Some Problems and Current Developments (pt. 2), 52 J. PAT. \& TRADEMARK OfF. SOC'Y 757 (1970) (discussing confusion in Patent Office's "undue breadth" rejections).

192. See id. at 761-63; Brian P. O'Shaughnessy, The False Inventive Genus: Developing a New Approach for Analyzing the Sufficiency of Patent Disclosure Within the Unpredictable Arts, 7 FORdham InTELl. Prop. MEdia \& ENT. L.J. 147, 172, 199 (1996); In re Mayhew, 527 F.2d 1229, 1235 (C.C.P.A. 1976) (Baldwin, J., concurring):

\begin{abstract}
Beginning in 1970, we departed from a vast line of authority which permitted the PTO to reject claims under the second paragraph of $\S 112$ for "undue breadth." Up to that time, examiners quite frequently determined what they felt the invention was and rejected all claims which were broader than their conception of the invention, using the second paragraph of $\S 112$ as the statutory basis.
\end{abstract}

Before the 1952 Act, at least in "unpredictable" arts like chemistry, rejections for "undue breadth" focused on the lack of description and utility rather than the inability to make and use the invention. See generally In re Langmuir, 62 F.2d 93, 95 (C.C.P.A. 1932). (holding that claims may not be broader than the disclosure "in chemical cases and cases where the properties of materials are concerned."); Samuel S. Levin, Broader than the Disclosure in Chemical Cases, 31 J. PAT. \& Trademark Off. Soc'Y 5 (1949). An example of the "properties of materials" doctrine appears to be In re Marshall, 54 F.2d 421, 423 (C.C.P.A. 1932). (affirming rejection because applicant had not disclosed metals with hardness or general physical characteristics recited by application's claims).

193. See Irah H. Donner, Patent Prosecution: Practice And Procedure BEFORE THE U.S. PATENT OFFICE (1996) at 503 (citing amendment as example of general principle that claims must encompass subject matter disclosed in the description); $i d$. at 500-01 (characterizing In re Fisher, 427 F.2d 833 (C.C.P.A. 1970) as a written 
precedent seems hard to reconcile with the notion that original claims require no disclosure beyond enablement. If claims themselves satisfactorily disclose the subject matter they encompass, then prior art patents necessarily must disclose all enabled subject matter falling within their claims. This appears not to have been the case. ${ }^{194}$ Moreover, prior to Lilly, the Federal Circuit expressed the "priority-policing" test as whether later claims would have been rejected if filed with the original application. ${ }^{195}$ If there is no written description requirement applicable to originally filed claims, then such an expression is absurd: originally-filed claims cannot be rejected for lack of written description. Yet the Federal Circuit expressed the doctrine in those terms, implying either very careless word choice or recognition that original claims do not ipso facto constitute their own description. ${ }^{196}$

\section{B. What Written Description Is: A Doctrine of Definition}

Written description, then, is not about possession or priority alone. It is instead a general doctrine of disclosure. Critics have maintained that written description as articulated by Lilly is a special biotechnology rule

description case); O'Shaughnessy, supra note 192, at 180-81 (stating that written description compliance issues "might" arise from claim amendments).

194. See In re Benno, 768 F.2d 1340, 1346 (Fed. Cir. 1985) ("The scope of a patent's claims determines what infringes the patent; it is no measure of what it discloses."). In Benno, Judge Rich reasoned by analogy that Samuel Morse's infamously overbroad eighth claim would have anticipated the Telex if claims disclosed everything within their scope. On this analogy alone one could argue that patent claims only fail to disclose nonenabled subject matter within their scope. However, Benno was a simple mechanical case, and there was no allegation that the subject matter alleged to be within the prior art was not enabled by the prior art patent.

195. See U.S. Steel Corp. v. Phillips Petroleum Co., 865 F.2d 1247, 1251 (Fed. Cir. 1989) (explaining that test for whether claim in continuation application was entitled to benefit of filing date of parent application is whether claim would have been rejected for lack of support if filed with parent application). It is true that U.S. Steel discusses enablement and written description together under the question of "lack of support." However, Judge Markey in U.S. Steel does not suggest that lack of enablement would be the only grounds for rejecting the claim if filed with the parent application, and discusses at length a written description case. See id. (discussing In re Koller, 613 F.2d 819 (C.C.P.A. 1977)). Judge Markey, it should be noted, was at least initially opposed to the notion of a separate written description doctrine. See In re Barker, 559 F.2d 588, 594-95 (C.C.P.A. 1977) (Markey, C.J., "heartily" dissenting).

196. Even if Lilly had instituted for the first time a disclosure doctrine applicable to originally-filed claims, it is peculiar to criticize it on those grounds. Most statutory patent law is codification of judicial innovations, and modern patent law retains extremely significant common-law doctrines having no statutory basis, such as the Doctrine of Equivalents and the doctrine of inequitable conduct. 
requiring nucleotide-by-nucleotide disclosure of DNA molecules, or a rigid rule limiting patentees to disclosed embodiments alone. ${ }^{197}$ Such interpretations miss the point of Lilly. The written description requirement is a general requirement that the applicant for a patent define the invention according to traditional principles of logic. Consider the language of Lilly:

A description of a genus of cDNAs may be achieved by means of a recitation of a representative number of cDNAs, defined by nucleotide sequence, falling within the scope of the genus or of a recitation of structural features common to the members of the genus, which features constitute a substantial portion of the genus. ${ }^{198}$

Most analyses and criticisms of this key language from Lilly have focused on the Federal Circuit's demand for structure or sequence information to satisfy the written description requirement. ${ }^{199}$ Such analyses miss the more important point. Lilly's importance does not lie in how one describes a DNA molecule, but in how one describes a genus. The Federal Circuit demanded that the claimed genus, i.e., a genus of DNA molecules, be described either by disclosure of a representative number of species in the genus, or by disclosure of properties that are common to members of the genus. These two modes correspond precisely to the two modes of definition articulated in formal logic. Recitation of the features or properties of a genus corresponds to definition by intension, or definition per genus et differentiam. In this classical mode of definition, a thing is defined by specifying the proximate genus to which it belongs, and those properties which differentiate it from other members of the

197. See, e.g., Mueller, supra note 53, at 651 (arguing that Lilly's "per se rule that a claim to a cDNA must be described in terms of its specific nucleotide sequence" runs contrary to tradition that the patent system "provided more in terms of patent scope than merely those embodiments expressly disclosed by the inventor in her application.").

198. Regents of the Univ. of Cal. v. Lilly, 119 F.3d 1559, 1569 (Fed. Cir. 1997) (emphasis added). A "cDNA," or complementary DNA molecule, is a synthetic DNA molecule produced by reverse transcription of a messenger RNA encoding a protein such as human insulin.

199. See, e.g., Holman, supra note 48 , at $19 \mathrm{n.89}$ (collecting structural criticisms); Dan L. Burk \& Mark A. Lemley, Biotechnology's Uncertainty Principle, 54 CASE W. RES. L. REV. 691, 697-98 (2004) (stating that the written description requirement demands precise sequence data); see also Amgen Inc. v. Hoechst Marion Roussel, Inc., 314 F.3d 1313, 1332 (Fed. Cir. 2003) (suggesting that Lilly was inapplicable because challenged patent disclosed a DNA sequence). 
genus. ${ }^{200}$ The alternative mode of description suggested by Lilly, enumeration of a representative number of members of the genus, corresponds to definition by extension, or definition by type. It proceeds by designating some individual or group of individuals as central or typical members of the genus and determining membership in the genus by degree of resemblance. ${ }^{201}$

Yet every claim is in the end a genus claim. ${ }^{202}$ Therefore, if Lilly provides a method to define and describe a genus, then Lilly provides a method to define and describe any claim. The Federal Circuit clearly understood itself to be promulgating a general doctrine of definition in Lilly. Holding that the inventors had not sufficiently described the genus of DNA molecules encoding mammalian insulin by the phrase "mammalian insulin cDNA," the standard the court employed was one of definition:

It does not specifically define any of the genes that fall within its definition. It does not define any structural features commonly possessed by members of the genus that distinguish them from others. One skilled in the art therefore cannot, as one can do with a fully described genus, visualize or recognize the identity of the members of the genus. ${ }^{203}$

200. See, e.g., Peter Coffey, THE SCIENCE of Logic 94 (1912) ("In order, therefore, to define any object of thought, we must find out and indicated its proximate genus - the next highest class into which it naturally falls-and the attribute or group of attributes which distinguishes it from other cognate species of the same genus.") (citation omitted).

201. See id. at 98 . In linguistics the notion of a family gathered around a type is often attributed to Wittgenstein, but the idea was in circulation well before. See JOHN NEVILLE KEYNES, STUDIES AND EXERCISES IN FORMAL LOGIC 34 (1884). Note that in some respects the intensional and extensional modes of definition also correspond to the peripheral and central modes of patent claiming. The topic of definition in patent law and its implication for the structure and interpretation of claims deserves far fuller treatment than can be accorded here.

202. See supra Part III.A.1.

203. Lilly, 119 F.3d at 1568 (emphases added). The theme of mental processvisualization or recognition-in the doctrine of written description seems to have derived from Amgen, Inc. v. Chugai Pharm. Co., 927 F.2d 1200 (Fed. Cir. 1991). Amgen was an infringement action in which the question of priority of invention for a DNA molecule encoding erythropoietin was in dispute. As set forth by 35 U.S.C. $\S 102(\mathrm{~g})$, an inventor may initially establish priority by demonstrating earlier conception of the invention. Conception in patent law is an entirely mental act, though it must be demonstrated by some objective disclosure. The court in Amgen held that an inventor who had failed "to envision the detailed chemical structure of the gene so as to distinguish it from other materials" could not establish conception until he had actually isolated the claimed DNA 
By expressing the written description doctrine as a doctrine of definition, the Federal Circuit provided, at least in theory, both a coherent rationale and a coherent test for application of the written description doctrine. Had Lilly's lead been followed, the true role of the written description doctrine, and how it differs from that of enablement, might have become clear.

\section{Losing the Path}

Unfortunately, since Lilly, the written description doctrine has gravitated back to the quixotic notion of "possession." 204 This trend is especially evident in the evolution of the PTO's Guidelines ${ }^{205}$ for assessing patent applications for compliance with the written description requirement. The initial Guidelines, issued in response to Lilly, explained the doctrine of written description in terms of possession. However, the Guidelines also framed written description as a doctrine of definition as articulated in Lilly. For generic claims, the Guidelines suggested that the specification must allow "one skilled in the art [to] readily envision a sufficient number of members of the claimed genus to provide written description support for the genus."206 Thus, the written description inquiry was to proceed by asking whether the inventor had conveyed enough information for one of ordinary skill in the art to define the genus by its intension. Likewise, satisfying the requirement by disclosure of common characteristics was judged by whether one of skill in the art could "reasonably predict sufficient identifying characteristics of the other members of the genus and, thus establish possession of the genus."207

In subsequent revisions of the Guidelines, the PTO eliminated the definitional aspect of the written description doctrine and focused entirely on the notion of possession. The result was an essentially tautological expression of the doctrine:

molecule. Fiers v. Revel, 984 F.3d 1164, 1168-69 (Fed. Cir. 1993) (discussing Amgen, 927 F.2d 1200).

204. The notion of possession may well have utility in other contexts; the point is that possession is not sensible in the context of written description.

205. See Guidelines for Examination of Patent Applications Under the 35 U.S.C. 112, 1, “Written Description" Requirement, 66 Fed. Reg. 1099, 1104 (Jan. 5, 2001) [hereinafter Guidelines].

206. Request for Comments on Interim Guidelines for Examination of Patent Applications Under the 35 U.S.C. 1121 "Written Description" Requirement, 63 Fed. Reg. 32,639, 32,641 (June 15, 1998) (citing Regents of the Univ. of Cal. v. Lilly, 119 F.3d 1559 (Fed. Cir. 1997)).

207. Id. at 32,642 . 
To satisfy the written description doctrine, a patent specification must describe the claimed invention in sufficient detail that one skilled in the art can reasonably conclude that the inventor had possession of the claimed invention. An applicant shows possession of the claimed invention by describing the claimed invention with all of its limitations. ${ }^{208}$

In other words, one describes the invention by showing possession, and one shows possession by describing the invention. With respect to genus claims, the revised Guidelines discarded the notion that the specification must convey enough information to permit one of skill in the art to envision or predict characteristics of members of the genus. Rather, the question was whether "the applicant was in possession of the necessary common attributes or features of the elements possessed by the members of the genus in view of the species disclosed." 209 It may be difficult enough to understand how to "possess" a genus of inventions, which are at least discrete objects or processes. It seems even more difficult to understand how to "possess" attributes or features of the genus. The patentee may possess a thing such as a red ball, and perhaps somehow a genus of red balls, but by what means do we assess whether he possesses "red"? ?10

Further muddying the nature of the doctrine, the revised Guidelines added that possession could be shown if the specification described an actual reduction to practice, or sufficiently disclosed to indicate that the invention was "ready for patenting." 211 These standards were imported from the Supreme Court's opinion Pfaff $v$. Wells Electronics, Inc., a case that decided at what point of development inventions could be considered "on sale" for purposes of novelty. ${ }^{212}$ Pfaff held that an invention was

208. Revised Interim Guidelines for Examination of Patent Applications Under the 35 U.S.C. $\$ 112$, P 1 "Written Description" Requirement, 64 Fed. Reg. 71427, 71434 (Dec. 21, 1999) [hereinafter Revised Guidelines]. The final revision of the Guidelines added that "describing the claimed invention with all of its limitations" could be achieved by "using such descriptive means as words, structures, figures, diagrams and formulas that fully set forth the claimed invention." Guidelines, 64 Fed. Reg. at 1104.

209. Revised Guidelines, 64 Fed. Reg. at 71436; Guidelines, 66 Fed. Reg. at 1106.

210. By framing the inquiry as whether the inventor showed possession of properties of the genus, the Patent Office seems to have committed itself to a form of metaphysical realism, the position descending from Plato that universals have an independent and objective existence outside of the particulars that instantiate them.

211. Revised Guidelines, 64 Fed. Reg. at 71429 (adopting suggestions to incorporate Pfaff analysis).

212. See Pfaff v. Wells Elecs., Inc., 525 U.S. 55 (1998). 
"ready for patenting" if it was actually reduced to practice, or if the inventor had prepared drawings or other descriptive material sufficient to enable practice of the invention. ${ }^{213}$ The Guidelines incorporated the Pfaff standards in response to comments suggesting that the Pfaff analysis was pertinent to the written description analysis. ${ }^{214}$ Yet the relevance of the Pfaff standard to the written description doctrine is hard to fathom. In order to encourage prompt filing of patent applications, the Pfaff standard was set to trigger the on-sale bar no earlier than the point when the inventor could patent the invention; if the invention was not yet ready for patenting then the law ought not to penalize the inventor. However, the Pfaff standard seems intended to identify the point in time at which the inventor could describe the invention to satisfy the standard of section 112, not to determine whether the inventor did describe the invention within the meaning of section $112 .{ }^{215}$ The logic of incorporating the Pfaff standard appears to rest on the notion of written description as possession: if reduction to practice shows possession of the invention, and if the Supreme Court mentioned reduction to practice as an alternative to "drawings or other descriptions," then a reduction to practice is a form of description. But such reasoning, apart from ignoring the Supreme Court's emphasis on an enabling disclosure, commits an elementary error of logic by assuming that if both description and reduction to practice indicate "ready for patenting," then reduction to practice equates to description. ${ }^{216}$

More importantly, the Pfaff inquiry, a tool for assessing whether the statutory bar to patenting has been triggered, is unhelpful for a doctrine of claim scope. As explained in Part II, the statutory bar (like other provisions of section 102) is triggered by any overlap between the set defined by the claim and the set of prior art. If any one embodiment of the claimed invention was sold and was ready for patenting under the Pfaff

213. See id. at 67.

214. See Revised Interim Guidelines, 64 Fed. Reg. at 71429.

215. Before the approach of the Guidelines, Professor Holbrook suggested that the "ready for patenting" inquiry explicitly incorporate an enablement analysis. See Timothy R. Holbrook, The More Things Change, the More They Stay the Same: Implications of Pfaff v. Wells Electronics, Inc. and the Quest for Predictability in the On-Sale Bar, 15 BERKELEY TECH. L.J. 933, 968-74 (2000). I have no quarrel with incorporating disclosure notions into the "ready for patenting" analysis; what seems awkward is the reverse.

216. The logic appears to be of the form: Socrates is a Greek. Plato is also a Greek. Therefore, Plato is Socrates. Ironically, one commentator argues that Pfaff is incompatible with the existence of a separate written description requirement. See Limin Zheng, Note, Purdue Pharma L.P. v. Faulding Inc., 17 BerKeley TECH. L.J. 95, 109 (2002). 
standard, then the claim is invalid under section 102(b). In contrast, a mere intersection between what was described and what was claimed does not satisfy the disclosure requirements of section 112. Satisfaction of the Pfaff standard may show that the inventor described something within the scope of the claims, but that sheds little light on whether the inventor described the set of all things encompassed by the claim.

The Federal Circuit has endorsed the PTO's Guidelines, ${ }^{217}$ while simultaneously emphasizing that a patent specification may demonstrate "possession" but still fail to provide a written description of the invention. ${ }^{218}$ However, the court also phrased the written description inquiry as whether the applicant has "demonstrate[d] possession of the generic scope of the claims." ${ }^{19}$ In subsequent opinions, the court has continued to assess the adequacy of support for a generic claim by asking whether the written description demonstrates that "the patentee possessed the full scope of the invention." 220 The possession inquiry, at least as currently constituted, cannot support or explain how written description functions as a limitation on claim scope.

217. See Enzo Biochem, Inc. v. Gen-Probe Inc., 323 F.3d 956, 964 (Fed. Cir. 2002) ("We are persuaded by the Guidelines on this point and adopt the PTO's applicable standard for determining compliance with the written description requirement."). Formally, the court's endorsement of the Guidelines might be read to extend only to the point addressed in that section of the Enzo opinion-the use of correlated structural and functional properties to describe claimed subject matter. Id. However, the Enzo court's remand instructions explicitly directed the district court to judge the broader questions whether the genus was adequately described according to the Guidelines. Id. at 967-68.

218. Id. at 969 (explaining that possession is ancillary to the statutory requirement of written description).

219. Id. at 966.

220. See LizardTech, Inc. v. Earth Res. Mapping, Inc., 424 F.3d 1336, 1345 (2005); see also Univ. of Rochester v. G.D. Searle \& Co., 375 F.3d 1303, 1307 (Fed. Cir. 2004) (Lourie, J., concurring in the denial of rehearing en banc) ("[T]he issue may still remain in a given case, especially with regard to generic claims, whether an original claim conveys that one has possession of and thus has invented species sufficient to constitute the genus."). However, there are encouraging signs that at least the Board of Patent Appeals and Interferences has moved away from reliance on possession. For example, in Ex parte Porro, No. 2008-0184, 2008 WL 2259960 (B.P.A.I. Mar. 11, 2008), the Board assessed the compliance of claims to a method of making vitamin $C$ in genetically engineered yeast. The Board's analysis focused on whether one of ordinary skill in the art could visualize or recognize members of the claimed genus; "possession" was invoked only as the ultimate legal conclusion. 


\section{Anchoring the Definitional Hierarchy}

Once we recognize written description as a method of logical definition, then its function in determining claim scope becomes clear. The system of definition in classical logic postulated hierarchical trees or chains of categories, each category being differentiated from the category above it by some necessary and essential characteristic property. ${ }^{221}$ In the classical example, a human is defined and distinguished from all other things by successively narrower genera, until we reach the level of the individual person:

Objects

Material Objects

Living Objects

Animals

Humans

(Socrates)

We could construct a similar chain focusing on the rat insulin DNA molecule at issue in Lilly:

DNA

Vertebrate DNA

Vertebrate insulin DNA

Mammalian insulin DNA

Rat insulin DNA

(Particular variant of rat insulin DNA)

The written description requirement anchors claim scope to a particular level within the chain of definition. The inventor who has discovered and disclosed only rat insulin DNA is not entitled to claim higher categories, such as "vertebrate insulin DNA," because the inventor has defined the genus neither by properties that distinguish it from other genera, nor by a set of types by which the genus can be recognized by degree of resemblance. Nor is the inventor entitled to claim a particular variant of rat insulin DNA, unless the differentia - in this case, the structural distinction between the variant and the type-of that species can be derived from the inventor's disclosure.

221. This scheme is generally known as the Tree of Porphyry, as it was set out explicitly in Porphyry's Isagogue, a commentary on Aristotle's Categories. See COFFEY, supra note 200 , at $78-9$. 
By anchoring claim scope within the hierarchy of definitional genera, written description deals directly with the question of claim scope and has the potential to resolve formal questions of claim scope in a way that enablement cannot. If written description was necessary solely to rationalize the formal structure of claiming, that would be little reason to maintain the doctrine. But of course the question of properly locating a patent's scope within the definitional hierarchy is critical to the policies of the patent system. In its traditional role in chemical practice, the written description doctrine prevented the inventor of a broader genus from reaching down the definitional chain to claim enabled but undisclosed members of that genus. Such function is necessary if we are to preserve the incentive for later inventors to develop improved or otherwise favorable members of the known genus. ${ }^{222}$ If description of the genus necessarily described every member of the genus, patents on favorable members of the genus would either be unobtainable or the property of the inventor of the genus. ${ }^{223}$ To use the example based on Lilly, suppose that particular synthetic variations of the rat insulin gene have properties making them more valuable than ordinary rat insulin. By forbidding the patentee who has disclosed the structure of rat insulin DNA from claiming those improved variants, inventors can patent subsequently discovered improved variants. ${ }^{224}$

Likewise, written description limits the inventor from reaching too far upwards on the definitional chain. This, according to some commentators, is the novel and heretical aspect of Lilly. However, once the role of written description is seen as properly locating claim scope in the definitional hierarchy, restrictions on upward reach seem as reasonable as restrictions on downward reach. Again, the goal must be to preserve incentives for

222. Such members of the genus must still be nonobvious over the genus in order to be patentable.

223. If the generic disclosure sufficed to disclose the members of the genus, then the patentee would be entitled to claim them as they were described in his original specification. If not claimed by the patentee, they would be thereafter be unpatentable, having been made "prior art" by the provisions of section 102. This balance further illustrates the necessity of the written description doctrine. Given that all things enabled by a disclosure do not become prior art, it would be curious to conclude that a species enabled but not described by the specification is always disclosed for purposes of section 112, the patentee's right to claim it, but not for purposes of section 102, a subsequent inventor's right to claim it.

224. Such variants would still infringe the generic inventor's patent, of course. Nonetheless, patents on a favorable embodiment are valuable, though less valuable than they would be in the absence of the generic patent. 
later inventors but the doctrine has more bite: no one ${ }^{225}$ is entitled to a patent on the broader genus such as "mammalian insulin DNA," though patents on cognate genera (such as "human insulin DNA") are still available. If the original inventor has indeed enabled the broader genus, ${ }^{226}$ there would seem to be little difficulty in the inventor accumulating the information necessary to define the genus under the written description doctrine. The argument that the inventor who has enabled the broader claim ought to be entitled to it regardless of his ability to describe it seems to carry the seeds of its own destruction: if accumulating the information needed to describe the genus is difficult and time-consuming, though "enabled," then perhaps enablement is doing a poor job of implementing the quid pro quo of the patent system. 227

Phrasing the scope problem in terms of the definitional hierarchy makes the Lilly upward-limiting aspect of the written description doctrine a natural extension of the traditional downward-limiting aspect of the doctrine. Likewise, once we understand that all claims are genus claims, we can understand that (1) the doctrine of written description is applicable to all categories of inventions, not just biotechnological inventions, and (2) satisfaction of the requirement is usually a matter of course for categories like simple mechanical inventions. The genus of "chairs with four legs" is much larger and more variable then a genus like "mammalian insulin DNA." ${ }^{228}$ Yet, if presented with a disclosure embodying the novel

225. The disclosure of a species anticipates the broader genus. This doctrine is necessary to prevent the generic inventor from removing species from the public domain.

226. Assuming we have a coherent way to answer this question.

227. This argument in some ways resembles the one made by Kitch's prospect theory: that even once the point of patentability has been reached (here, enablement of the genus) significant investments may be necessary to identify commercially useful embodiments of the genus. Edmund W. Kitch, The Nature and Function of the Patent System, 20 J.L. \& ECON. 265 (1977). Kitch's solution was to grant the original inventor a broad patent, enabling him to coordinate the process of commercial development. Critics who doubt the ability of patentees to coordinate development would deny the broad patent to maximize incentives for others to develop commercial embodiments. If those critics are correct, then the inventor who 'enables a genus' should not necessarily obtain a patent covering the entire genus.

228. We may postulate an infinite variety of dimensions, materials, decorative qualities, etc. for chairs. In contrast, there are 4,000 to 5,000 mammalian species; if the insulin gene is different in each species then there are at most 4,000 to 5,000 mammalian insulin genes. Of course one can postulate an infinite number of DNA molecules that encode a mammalian insulin polypeptide, by adding non-coding sequences or varying the sequence of the insulin polypeptide, but such changes in DNA sequence are qualitatively much simpler than the transformations that can be imagined of chairs. 
inventive idea of placing four legs on a seating surface, one of ordinary skill in the art would readily grasp the concept of the genus of all chairs with four legs, and envision any given member of the genus. ${ }^{229}$ Viewed in this light, the application of the written description doctrine to "ordinary" inventions should be uncontroversial.

Take the case of Gentry Gallery Inc. v. Berkline Corp., ${ }^{230}$ viewed by many commentators as a prime example of the written description requirement run amok. The disclosure of the patent in Gentry described a sofa with two reclining seats, controls for the recliners being located on a console between the seats. The Federal Circuit held that a claim which did not fix the location of the controls on the console was invalid for failure to satisfy the written description requirement, because the patent disclosed only controls mounted on the console. ${ }^{231}$

Had the court treated the problem as one of broader and narrower genera, the claims might have been held valid. The question would have been whether the disclosure of a narrower genus, sofas with controls mounted on a console, would have permitted one of ordinary skill in the art to envision the broader genus of sofas with controls mounted elsewhere on the sofa. If locating the controls on the console was not necessary for the function of the sofa, then one of ordinary skill in the art would likely have been able to envision a genus of sofas with controls located elsewhere than the console. If the sofa arts are predictable arts, then based on the properties of the sofa with console-mounted controls, one skilled in the sofa arts would likely have been able to predict the properties of sofas belonging to the broader genus. Gentry Gallery therefore represents not an aberrant application of a biotechnology doctrine to a mechanical patent, but a failure to recognize that the principles of genus and species explicit in chemical and biotechnological practice are inherent in every category of invention.

229. This is not the same as being able to make and use any member of the genus. One of skill in the art can envision a chair made of neutronium, and perhaps predict its properties, but cannot make and use one. Even if the fashioning of furniture from neutronium is known in the art, actually making a chair from neutronium may require unforeseeable advancements that by definition could not have been envisioned by one of ordinary skill in the art.

230. Gentry Gallery, Inc. v. Berkline Corp., 134 F.3d 1473 (Fed. Cir. 1998).

231. Id. at 1480 . 


\section{THE SIGNIFICANCE OF DEFINITIONAL INFORMATION}

It would be overly ambitious, in this Article, to attempt to provide a comprehensive methodology for assessing the sufficiency of definitional information, or circumscribe precisely the proper spheres of written description and enablement. ${ }^{232}$ Such questions as whether the patentee has provided sufficient representative members for a definition by extension, or what constitutes degree of resemblance in a particular instance, will be complex factual inquiries in some cases. There is no escaping such difficulties in patent law. But at least treating the question as one of definition provides a principled intellectual framework to decide questions of genus and scope, rather than an ad hoc approach. This final section briefly considers the significance of a definitional information requirement, why it ought to be lodged in the doctrine of written description, and how treating written description as a doctrine of definition changes our view of other facets of patent law.

\section{A. Consequences of an Obligation for Definitional Information}

At the most general level, the patent system's disclosure doctrines control the balance between initial and follow-on inventors by dictating how broadly an earlier inventor may claim under a given disclosure. ${ }^{233}$ Preferences for that set-point depend largely on whether one views broad or early patent rights as conducive to innovation. ${ }^{234} \mathrm{~A}$ patent system might set that balance via enablement, written description, or other doctrines. For the purposes of this Article, the question is not where that balance should be set but what doctrinal theories and tools are best suited to achieve that result. ${ }^{235}$

The enablement inquiry tends to be fact-intensive, requiring evidence of what one of ordinary skill in the art could or could not accomplish with

232. In "easy" disclosure cases the same information will likely satisfy the definitional requirement and enable at least some of the subject matter of the patent.

233. See Rebecca S. Eisenberg, Patents and the Progress of Science: Exclusive Rights and Experimental Use, 56 U. CHI. L. REV. 1017, 1024-46 (1989) (discussing theories of innovation and patent scope).

234. See generally id. (analyzing effect of broad patents on biomedical research).

235. Burk and Lemley favor increased use of judicial "policy levers" to adjust a statutorily uniform patent law to the technologically heterogeneous innovation economy. See generally Dan L. Burk \& Mark A. Lemley, Policy Levers in Patent Law, 89 VA. L. REV. 1575 (2003). They identify the written description doctrine as an existing policy lever, see id. at 1652-54, though they disagree with how the Federal Circuit has pulled it. See id. at 1682-83; id. at 1688-89 (criticizing Federal Circuit application of disclosure requirements in biotechnology and software cases). 
certain efforts given the state of the art. The inquiry may require extensive expert testimony and may not be amenable to early judicial intervention. In contrast, written description is a question of what the patent specification discloses: does the text of the patent disclose the invention defined by the claims? No less than most other inquiries in patent law, this question is resolved from the perspective of one of ordinary skill in the art. Nevertheless, the underlying question in written description, what information is conveyed by the patent specification, may be more capable of judicial resolution than questions about the behavior or thought processes of technological artisans. ${ }^{236}$ To the extent that we desire more judicial control over patent scope and desire such control not be confined by the particular testimony adduced in a given case, ${ }^{237}$ written description may be a more appealing doctrine than enablement.

236. This argument is not supported by the current standards of appellate review. Enablement and nonobviousness are treated as issues of law with underlying factual components, whereas written description is treated as an issue of fact. However, in practice, the nature of the inquiry - content of a text versus the mindset or capability of one of ordinary skill in the art-may well be more important than the nominal standard of appellate review. The current "factual" state of written description is in any event curious. It derives from the Court of Customs and Patent Appeals' statement in In re Ruschig:

[W] de doubt that the rejection is truly based on section 112 , at least on the parts relied on by appellants. If based on section 112 , it is on the requirement thereof that "The specification shall contain a written description of the invention.". . . We have a specification which describes appellants' invention. The issue here is in no wise a question of its compliance with section 112 , it is a question of fact: Is the compound of claim 13 described therein?

In re Ruschig, 379 F.2d 990, 995-96 (C.C.P.A. 1967). Ruschig was subsequently cited for the proposition that written description issues were questions of fact. See In re Wertheim, 541 F.2d 257 (C.C.P.A. 1976) (quoting Ruschig for proposition that written description requirement is issue of fact). Moreover, the Court of Customs and Patent Appeals was not particularly deferential to the PTO on issues of fact. See In re Zurko, 142 F.3d 1447, 1454-55 (Fed. Cir. 1998) (discussing the Court of Customs and Patent Appeals review of Patent Office decisions), rev'd, 527 U.S. 150 (1999).

237. Burk and Lemley argue that judges should have substantial discretion to adjust policy levers. See Burk \& Lemley, supra note 235 , at 1668 . They seem to suggest that industry-tailored policy discretion should be informed by legal and economic scholarship rather than emphasis on the facts of the particular case. See id. at 1671. Certainly on the question of disclosure the Federal Circuit has explicitly eschewed policy-based rulings and chosen instead to decide cases based on the evidence before the district court and the standard of review. See, e.g., Amgen Inc. v. Hoechst Marion Roussel, Inc., 314 F.3d 1313, 1337 (Fed. Cir. 2003) ("The dissent, however, does not directly challenge the court's factual findings, nor does it mention the decisions relied on by the district court. Instead, it finds fault in the absence of discussion of [section 112 precedent], and makes 
The conception of written description this Article advances emphasizes the significance of definitional information provided by the patentee. Setting aside for a moment the question of which doctrine demands such information, we may observe that patent theorists have already recognized the importance of definitional information, even if it has long been overshadowed by other aspects of patent disclosure. Edmund Kitch, in his seminal work on prospect theory, maintained that the patent system was superior to a government auction system because the patent system provided incentives for private parties to identify and define claims. ${ }^{238}$ The premise of Kitch's argument is that definitional information is costly and does not appear of its own accord. Indeed, with Kitch's emphasis on the patent as a prospect for future development, the primary role of the patent specification was to provide definitional information. Believing that patentees had independent incentives to disclose enabling information and better ways to do so than within the formal constraints of the patent document, Kitch argued, "The purpose of the description in the patent is not to disclose the commercially relevant technology, but to provide a context in which the legal limits of the claim acquire meaning. ${ }^{239}$ Likewise, more recent theories of the patent system that look beyond the incentive or reward functions of the patent also emphasize the importance of definitional information, rather than technological disclosure per se, in setting the scope of the patentee's rights. ${ }^{240}$

broader arguments seemingly based upon policy considerations."). It is somewhat difficult to reconcile this sort of reasoning with Burk and Lemley's identification of "more intrusive appellate review" as the reason for lack of policy direction. See Burk \& Lemley, supra note 235 , at 1671 . In any event, the argument for increased judicial discretion seems to support the existence of an independent written description requirement, if only as an additional lever to adjust aspects of the patent system that enablement has difficulty controlling.

238. Kitch, supra note 227 , at 265,266 n. 4 .

239. Id. at 287 . Although the patentee's disclosure of his or her technological advance lies at the heart of many theories of the patent system, there is little known about whether such disclosure is significant for technological progress. See Rebecca S. Eisenberg, Analyze This: A Law and Economics Agenda for the Patent System, 53 VAND. L. REV. 2081, 2093-94 (2000) (noting lack of data on disclosure functions of patent specification); see also Holbrook, supra note 62, at 131-46 (arguing against "teaching" function of enablement).

240. See F. Scott Kieff, The Case for Registering Patents and the Law and Economics of Present Patent-Obtaining Rules, 45 B.C. L. REV. 55, 99 (2003) (arguing that independent written description requirement decreases social costs under a registration theory). 
The economic significance of definitional information is also inherent in Meurer and Nard's game-theoretic analysis of the Doctrine of Equivalents. ${ }^{241}$ Meurer and Nard suppose that, for a certain level of investment, an inventor discovers a quantum of information that suffices to enable a broad set of embodiments, but only permits the inventor to claim a more limited set of embodiments. In the model, the inventor chooses between investing further "refining" so as to be able to claim the broader set, or resting upon a claim to the narrower set and relying upon the DOE for the rest. ${ }^{242}$ The analysis therefore assumes that the initial investment provides enough information to enable a genus, but not to claim it literally.

In Meurer and Nard's treatment, the additional "refinement costs" that the patentee may spend to expand his literal claim scope are directed towards identifying and claiming the subject matter enabled by the patent disclosure. ${ }^{243}$ These costs might represent the time necessary to imagine additional embodiments of the invention, and to formulate more expansive claim language to cover additional embodiments. ${ }^{244}$ However, the analysis is equally valid if we view "refinement" as the process of developing more definitional information necessary to describe claims of broader scope. ${ }^{245}$ What the inventor may claim literally on a given disclosure is determined by the disclosure doctrines of section 112 . Thus an inability to claim literally the broader set of embodiments might reflect inability to formulate appropriate claim language without further investment, or it might reflect an inability to satisfy the disclosure obligations of section 112 with respect to known claim language or embodiments. If additional claim drafting and additional disclosure are interchangeable from the perspective of refinement costs, then the economic consequences of a weak written description regime versus a strong written description

241. Michael J. Meurer \& Craig Allen Nard, Invention, Refinement and Patent Claim Scope: A New Perspective on the Doctrine of Equivalents, 93 GEO. L.J. 1947 (2005).

242. See id. at 1983-84 (setting forth model in which investment $W$ enables embodiment set $F$ but only permits inventor to literally claim set $E$ ).

243. See id. at 1984.

244. See id. at 1985 (assuming inventor may literally claim larger set after "mentally identifying the embodiments" in the set). One suspects that a large portion of this cost would end up being the cost of patent attorneys.

245. The Court of Customs and Patent Appeals seems to have been cognizant of this process early on. See In re Clarke, 356 F.2d 987, 992 (C.C.P.A. 1966) (describing situation where inventor has recognized that invention was generic, and "was endeavoring to determine by exercise of reasonable diligence the precise scope of the invention"). 
regime generally follow those of a strong DOE versus weak DOE regime. ${ }^{246}$

This parallelism should hold beyond the costs and benefits of permitting patentees to assert patents against broader ranges of subject matter: just as a strong DOE regime tends to erode the notice function of patent claims by permitting a patentee to reach beyond the literal boundaries of the patent, a regime with weak obligations of definitional information is likely to yield less certain patent claims. ${ }^{247}$ Defining the true genus of the invention not only anchors the patent right at a particular level of generality, but also serves to more precisely define the boundaries of the patent.

Given that definitional information is real and costly, how important is it to demand such information from the patentee? It is perhaps very important. Certainty in the boundary of the patent right is central to the purposes of the patent system, ${ }^{248}$ and recent critiques attribute many of the problems of our current system to our inability to precisely define the scope of patent claims. ${ }^{249}$ We might therefore regard an obligation to provide definitional information as part and parcel of the patent quid pro quo, along with the more familiar obligation to disclose the technological details of the invention's advance.

246. Meurer and Nard show that the behavioral consequences of these regimes depend on the magnitude of the cost of refinement versus the cost of invention, and the returns expected from the monopoly or duopoly returns expected from the broader or narrower scope. See Meurer \& Nard, supra note 241.

247. The question of the interplay between disclosure and DOE is more complex than can be fairly treated in this Article. For a general treatment, though focused on the doctrine of prosecution history estoppel, see R. Polk Wagner, Reconsidering Estoppel: Patent Administration and the Failure of Festo, 151 U. PA. L. REV. 159 (2002). Two observations on the DOE are pertinent here. First, the problems of disclosure identified in this Article emanate from the peripheral claim system. To the extent that the DOE represents a retreat from the primacy of peripheral claiming, one response to the issues presented here might be to admit that the peripheral claim system has done all that we can reasonably ask of it, and to rely more heavily on the DOE for an integrated analysis of scope, validity, and infringement. Second, current case law hinders use of the DOE as a doctrine of claim scope. The public dedication doctrine of Johnson \& Johnston holds that a patentee who discloses but fails to claim subject matter is prohibited from reaching that subject matter under the doctrine of equivalents. See supra note 21 . The doctrine discourages patentees from including definitional information, or at least representative members, in their disclosures for fear that DOE coverage will be compromised.

248. See, e.g., Craig Allen Nard, Certainty, Fence Building, and the Useful Arts, 74 IND. L.J. 759, 785-95 (1999) (discussing importance of certainty in patent system).

249. See generally James Bessen \& Michael J. Meurer, Patent Failure: How JudGes, BUREAUCRATS, AND LAWYERS PUT INNOVATORS AT RISK (2008). 


\section{B. Meaning and the Place of Definitional Information in Patent Doctrine}

However, if definitional information is something that contributes to the certainty of patent claims, are we not referring to the definiteness requirement of section $112, \mathbb{2}$, rather than the disclosure requirement of section 112, | 1 ? In a sense we are if by "definiteness" we mean the ability to recognize the extent of legal rights deriving from disclosure of an invention. The current doctrine of claim definiteness was, along with enablement and written description, part of the vague category of "undue breadth" before the Court of Customs and Patent Appeals began differentiating the doctrines of section 112 as recognized today. ${ }^{250}$ Since that time, the doctrine of claim definiteness has been associated almost entirely with the lexical and syntactical clarity of claim language rather than the claimed subject matter or the disclosure. ${ }^{251}$ Likewise, in construing patent claims, we turn to the disclosure as a resource of meaning for claim language but we do not demand such meaning from the disclosure. Despite the Federal Circuit's recent emphasis on a contextual interpretation of claim language, ${ }^{252}$ the court is reluctant to turn to the disclosure as a source of definition unless particular claim terms are considered in need of interpretation. ${ }^{253}$ Nor is possible invalidity of the claim for overbreadth (or for other reasons) to be considered in claim interpretation except in extremis. ${ }^{254}$ Thus, in modern practice, the questions of scope, meaning, and clarity are, in the style of classical legal orthodoxy, largely independent inquiries governed by distinct analytical frameworks.

The notion of definitional information, however, partakes of scope, meaning, and clarity together. The existence of a concept straddling our current doctrinal boundaries may show us that the Court of Customs and Patent Appeals drew the boundaries between the doctrines of section 112 incorrectly, in which case much of this Article could be read as a call for a

250. See supra text accompanying notes 191-192.

251. See supra text accompanying notes 31-32.

252. See Phillips v. AWH Corp., 415 F.3d 1303, 1313 (Fed. Cir. 2005) (emphasizing role of context in claim interpretation).

253. See MBO Labs., Inc. v. Becton, Dickinson \& Co., 474 F.3d 1323, 1330-31 (Fed. Cir. 2007) (restricting analysis to claim words disputed by parties).

254. See Phillips, 415 F.3d at 1327 ("While we have acknowledged the maxim that claims should be construed to preserve their validity, we have not applied that principle broadly, and we have certainly not endorsed a regime in which validity analysis is a regular component of claim construction."). 
radically transformed doctrine of definiteness rather than a defense of the existing written description doctrine. Certainly a renewed emphasis on the definitional content of the disclosure would lead to increased reliance on the disclosure as a source of meaning for claim interpretation, even if the nominal doctrines of claim construction saw no changes. However, we are unlikely to find such meaning in the disclosure unless we begin to demand it from patentees. If we seek meaning only in the words of the claim, then the current doctrine of indefiniteness may impose an adequate obligation of definitional information upon the patentee. On the other hand, if we believe that the meaning of the inventor's rights must be found within a larger context, ${ }^{255}$ then the disclosure of the invention must become a more significant source of definitional information. ${ }^{256}$

Current enablement doctrine is not well-suited to enforce an obligation of definitional information. Enablement has difficulty grappling with the problems of genus and infinite claims. Instead, enablement is concerned with purely physical relations between entities in the physical world: the question of whether one of ordinary skill in the art could make or use a thing without undue time or effort is a physical function, even if its arguments (persons, things, and the acts of making and using) are hypothetical entities. ${ }^{257}$ In contrast, the relation between scope and definition is very much one of description; logicians and linguists have been grappling with the problems of description in these terms at least since Aristotle. The longevity of that effort may give us pause, but if we

255. See Christopher A. Cotropia, Patent Claim Interpretation Methodologies and Their Claim Scope Paradigms, 47 WM. \& MARY L. REV. 49, 105-24 (2005) (evaluating specification-oriented versus claim-language-oriented interpretive methodologies); Nard, supra note 21, at 43-64 (emphasizing importance of contextual information in claim interpretation). Professor Nard goes beyond the specification-oriented approach, arguing that to rely on the text of the patent alone disregards the social essence of language. $I d$. at 53-54.

256. This should not be read as a blanket endorsement of reading limitations from the disclosure into the claims; rather, viewing written description as a doctrine of definition may clarify when it is appropriate to limit the invention based on features disclosed in the description. If the patentee has employed the mode of definition by intension, then the features or properties disclose do indeed characterize "the invention" and should be implied into all its embodiments. If the patentee has employed definition by extension, the question becomes to what extent that particular feature is present in the genus derived by degree of resemblance to the type members. Again, the question may be a complex factual one, but perhaps the intellectual framework of definition provides a more rational guide than the current system for invoking limitations from the specification.

257. See Durham, supra note 75 , at $995-96$ (noting problem of applying obviousness inquiry to claim in abstract, rather than subject matter within the claim). 
treat scope problems in patent law at least in part as problems of definition, we will find a heritage of thought dedicated to the relationship between logical categories, language, and the physical world. ${ }^{258}$

\section{CONCLUSION: THE PAST AND FUTURE OF CLAIMING}

The problems posed by the necessity to define a genus did not arise prior to the development of the peripheral claiming system in its modern form. It is well-appreciated that the United States formerly followed a central system, in which the patentee described an embodiment of the invention and infringement was assessed by comparison between what the inventor had made or described and the accused subject matter. What is perhaps less appreciated is that, in their original form, claims were not considered to define subject matter in the same sense as modern claims. Early claims defined only the novel inventive principle the inventor created, not a category of objects or processes. ${ }^{259}$ Indeed, in early practice, a claim defining the structure of an operative machine with a novel inventive feature, as modern claims do, was invalid, for the inventor had included old features over which he had no rights along with the new and inventive feature to which he was entitled. ${ }^{260}$ If the "invention" is the novel principle discovered or created by the inventor, defined at the

258. See generally Collins, supra note 100 for a recent application of such thought to the problem of meaning of claims over time. A note of caution is in order here: there are perhaps deep difficulties with the classical notions of categories, at least as applied to human thought and language. See generally GEORGE LAKOFF, WOMEN, FIRE, AND Dangerous Things: What Categories Reveal about the Mind (1987). Such discrepancies between the system of classical categories, upon which claims are based, and the structure of human language and thought, may have significant implications for claim interpretation as well as the task of definition.

259. See, e.g. Winans v. Denmead, 56 U.S. 330, 343 (1853) (stating that invention "did not consist in a change of form, but in the new employment of principles or powers, in a new mode of operation, embodied in a form by means of which a new or better result is produced"). Today Winans is characterized as an early case on the DOE. Certainly the policy arguments for or against infringement in Winans are the same ones invoked for or against the DOE today, but in historical context Winans reflects a nonstructural methodology of defining "the invention." See Meurer \& Nard, supra note 241, at 1961-66 (discussing early "principle of the invention" cases and Winans). Lutz notes that in 1863 , a Patent Office rule expressly permitted a patentee to claim the inventive principle directly. See Karl B. Lutz, Evolution of the Claims of U.S. Patents, 20 J. PAT OFF. SoC'Y 457, 465 (1938) (quoting PTO's 1863 pamphlet, "Guide to Practice of the Patent Office").

260. See N. J. Brumbaugh, History and Purpose of Claims in United States Patent Law, 14 J. PAT. OFF. SOC'Y 273, 279-81 (1932) (discussing early cases that required claim to distinguish between old and new). 
appropriate level of generality, ${ }^{261}$ then it is possible to ask whether an accused infringer is implementing that principle without having to decide whether the inventor enabled the category of all things that employ that principle.

Under this regime that German patent law retained until the late 20th century, ${ }^{262}$ questions of claim scope, nonobviousness, and infringement were resolved as an integrated inquiry. The inventive principle contributed by the inventor was assessed in light of prior art, and claim scope and infringement were determined according to whether they embodied the inventive principle disclosed by the inventor. ${ }^{263}$ Under such a system, it is not necessary to define ex ante a category of objects over which the inventor may exercise exclusive rights. The disadvantage of such a regime is that a patent has no definite bounds, and the public cannot be certain what is infringing and what is not. ${ }^{264}$ Hence the development of the

261. Thus, for example, in characterizing an English patent, the Supreme Court in O'Reilly $v$. Morse stated that the inventor had not discovered the principle that hot air will promote the ignition of fuel better than cold air, but "he had invented a mechanical apparatus, by which a current of hot air, instead of cold, could be thrown in... . The interposition of a heated receptacle, in any form, was the novelty he invented."). O'Reilly v. Morse, 56 U.S. 62, 116 (1853). In O'Reilly itself the deficiency of Morse's eighth claim was that it was not limited to the recording structures disclosed in the specification, but the Court's discussion of the Neilson patent suggests it was breadth of the principle, rather than failure to limit by particular structure, that doomed Morse's claim. Then again, the similar division of the Justices in the contemporaneous Winans and O'Reilly cases may simply reflect disagreement on the Court between Justices who viewed claims as defining principles and those who viewed claims as defining structures. See Karl B. Lutz, Evolution of the Claims of U.S. Patents, 20 J. PAT. OfF. SoC'Y 377, 388 (1938) (discussing division of the Court).

262. Germany retained a central claiming system until 1973, when it joined the European Patent Convention. See Heinz Winkler, The Scope of Patent Protection: Past, Present, and Future, 10 INT'L REV. InduS. Prop. \& COPYRIGHT LAW 296 (1979).

263. This approach persisted well into the late 19th century, at least in the language of the decisions. See Swain Turbine \& Mfg. Co. v. Ladd, 102 U.S. 408, 414-15 (1880) (noting in context of interpretation that prior art waterwheels "contained the fundamental element ... which the appellant claims as the principle of Swain's invention."); see also In re Cawood Patent, 94 U.S. 695, 701 (1876) (discussing novelty and infringement in terms of "principle of the invention" rather than structure alone).

264. The uncertainty of central claiming did not seem to impede technological development in Germany during the late 19th and 20th centuries. However, the German economy, at least prior to World War II, was characterized by industrial concentration and infrequent patent litigation, rather than vigorous competition and commonplace litigation. See Heinrich Kronstein, The Dynamics of German Cartels and Patents, 9 U. CHI. L. REV. 643 (1992). These characteristics may have blunted any chilling effect of uncertain patent scope. 
modern American system of claiming: in which claims recite properties precisely defining a set of objects or processes over which the patentee asserts exclusive rights. ${ }^{265}$ As the notions of invention, claim, and legal right converged, the concepts of scope, infringement, and nonobviousness crystallized into distinct doctrines. However, in fixating upon a system in which legal rights were precisely delineated by a system of claims that defined not what the inventor had created, but to what he was entitled, patent law lost at least two advantages of the central claiming system: the ability to integrate information about patent validity and the technological advance represented by the invention into the infringement inquiry, ${ }^{266}$ and the ability to define the inventor's permissible entitlement in a theoretically rigorous manner.

So long as the structure of patent law remained less formal, the looseness of patent doctrine may have concealed the lack of a coherent theory of permissible claim scope. ${ }^{267}$ If so, then modern efforts to condense patent law into a conceptually ordered system have brought this deficiency into sharp relief. Perhaps we cannot resolve the problem of patent scope without abandoning, at least in part, the peripheral claiming system that lies at the heart of modern patent law. ${ }^{268}$ Yet if patent law is to

265. For a snapshot of the transition, see Brumbaugh, supra note 260 , at $283-84$ (describing rejection of forms in participial form in the early 1870 s).

266. The reverse doctrine of equivalents, by considering the relationship between the patentee's disclosed invention and the accused subject matter, retained some of the integrative features of the earlier system. But the doctrine has been essentially abandoned in favor of the modern practice of quarantined inquiries. See supra note 23.

267. Judge Learned Hand described resort to the doctrine of equivalents as a means "to temper unsparing logic." Royal Typewriter Co. v. Remington Rand, 168 F.2d 691, 692 (2d Cir. 1948).

268. Commentators who advocate modification of the enablement requirement, and the elimination of written description as a limit on originally filed claims, ultimately arrive at a rejection of the formal peripheral claiming concept, though they do not describe it as such. The foundation of the formal system is that claim scope, validity, and infringement are all independent entities; though claims are construed to preserve their validity, the scope of the claim is in theory fixed and the question of whether accused subject matter falls within the patent's claims is resolved without reference to the question of whether the patentee's disclosure enables that particular embodiment. Professor Holbrook, however, concludes that (as a matter of claim construction) "[i]n order to literally infringe the patent, the patent would have to enable the accused device, thus showing that the patentee had placed the PHOSITA in possession of it." Holbrook, supra note 62, at 158 (emphasis added). Likewise, Professor Feldman would frame the inquiry as "the leap that it will take to get from what the inventor actually disclosed to the product that the inventor is trying to reach." Feldman, supra note 158 , at 40 . She 
be a conceptually ordered system founded upon the peripheral claim, then the doctrine of written description, conceived as a doctrine of definition, will remain a necessary aspect of the law.

recognizes that this approach departs from the traditional notion that patent scope is determined without reference to the allegedly infringing material. Id. 
BERKELEY 'TECHNOLOGY LAW JOURNAL 